\title{
Early Eocene Palynology from Mead Stream, New Zealand
}

\author{
By \\ Thomas Foster Cooper
}

A thesis submitted to the Victoria University of Wellington as partial fulfilment of the requirements for the degree of Master of Science in Geology

School of Geography, Environment and Earth Sciences Victoria University of Wellington December 2017 



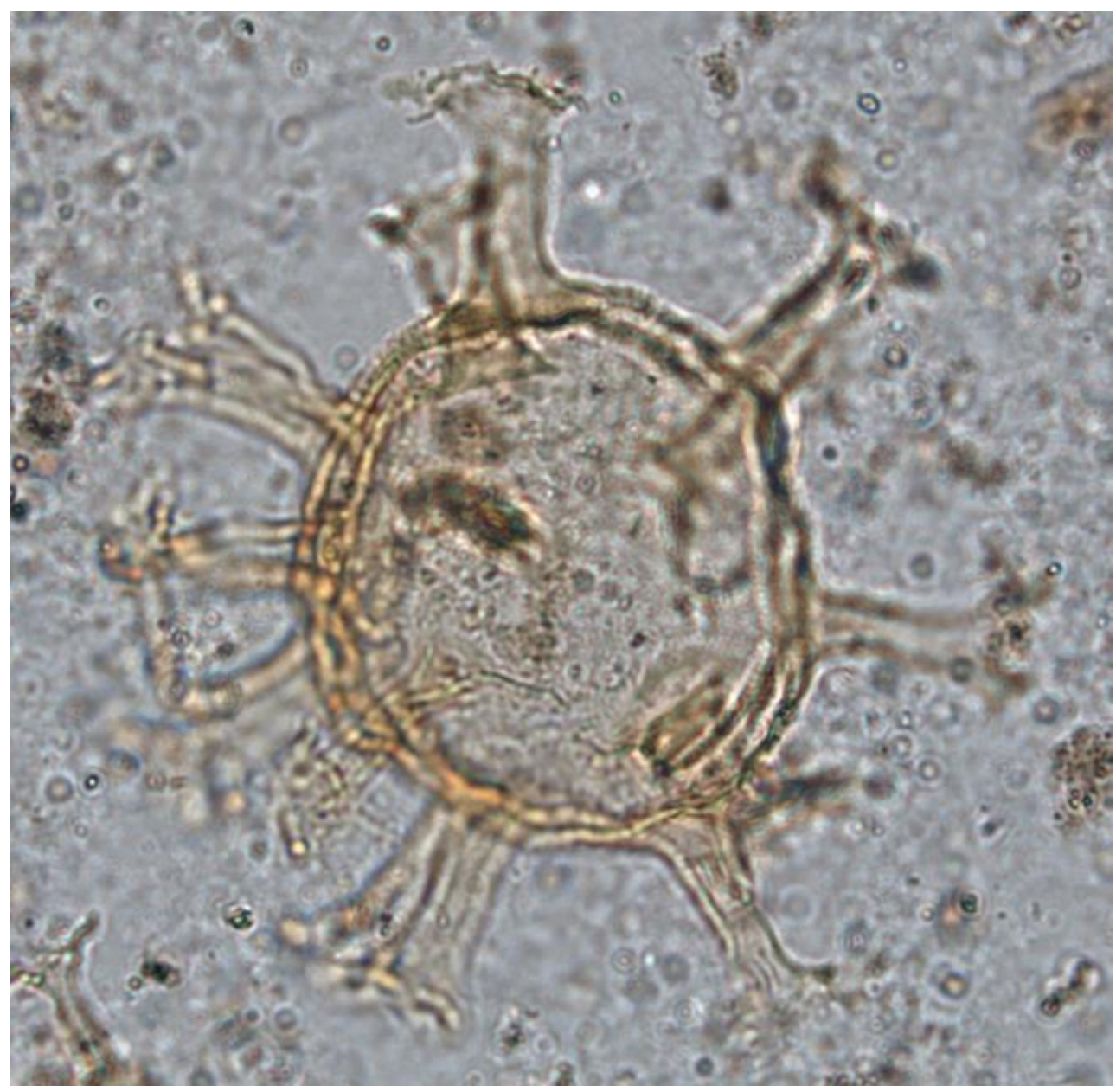

Dedicated to Philip Molony,

I think you would have enjoyed this. 


\section{Abstract}

This study documents the first detailed palynological analysis of early Eocene strata from the Lower Marl unit at Mead Stream, southern Marlborough, New Zealand. Examination of marine palynomorph assemblages and palynofacies analysis were used to improve biostratigraphic resolution and investigate paleoclimate across the Early Eocene Climatic Optimum (EECO; 53-49 Ma) - a period characterised by the highest temperatures of the Paleogene.

Early Eocene New Zealand dinocyst zones from NZE2-NZE4, and the Charlesdowniea coleothrypta zone are established across the Lower Marl for the first time in this study. Marine palynomorph assemblages originating in outer-neritic conditions and deposited on the upper slope represent low energy transport along the margin of a terrestrial discharge plume. Palynomorph assemblages do not provide insight into sea surface temperature (SST) trends. Palynomorph assemblages may reflect extremely low surface productivity. Cycles in organic matter between marine-dominant limestones to terrestrial-dominant marls, controlled by changes in temperature and seasonal precipitation, may represent orbital forcing by way of precession cycles; however the limited range of high resolution data from this study cannot statistically confirm this. An overall increase of allochthonous organic matter across the Lower Marl is likely representative of long-term background warming, culminating in peak EECO temperatures. The base of a hyperthermal, represented by carbon isotope excursion ( $\mathrm{CIE}$ ) previously identified at Mead Stream has been redefined in this study. High abundances of warm water, extreme salinity taxa coincide with the onset of this warming event. 


\section{Acknowledgements}

First and foremost I would like to thank my supervisors Mike Hannah and Erica Crouch, for all their help, support, advice, understanding, and most importantly for being so patient with me. Mike, I always leave your office feeling significantly more confident, and your constantly open door has been much appreciated. Erica, thank you for giving up so much of your time to poring over hundreds and hundreds of microscope photos every time I said I had "a few" I'd like to go over.

I would also like to thank Chris Hollis and James Crampton for all their advice and assistance, and Roger Tremain for help (and tolerating my presence) in the lab.

I would like to acknowledge the contributions of GNS Science, who funded field work and provided lab facilities for this project, as well as the Murray family for allowing access to Mead Stream.

Sonja, it's been pretty great to have someone to stumble through this with, your relentless and infectious enthusiasm has made a huge difference.

Josh \& Lauren, thank you for being such excellent partners in mischief since way back when this all began (far too long ago), and thanks to all the Co421 office mates that have come and gone, for all the help, all the sanity-preserving distractions, and for some great company.

Last but not least thank you so much to my family, particularly my parents, for standing by me and offering so much support throughout the last couple of years. I couldn't have done it without you guys. 


\section{Table of Contents}

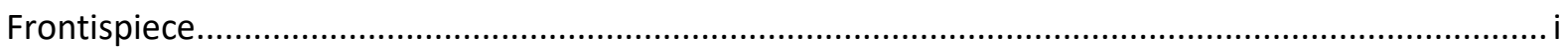

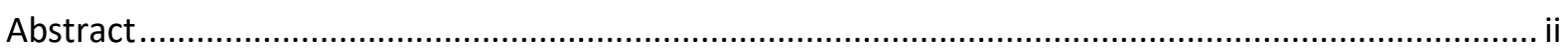

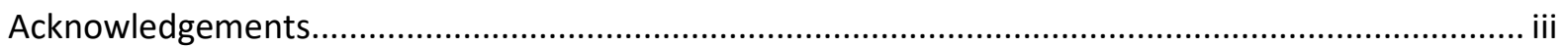

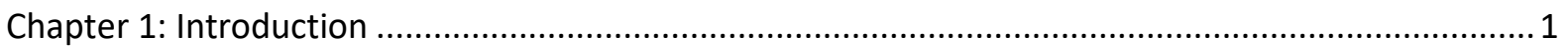

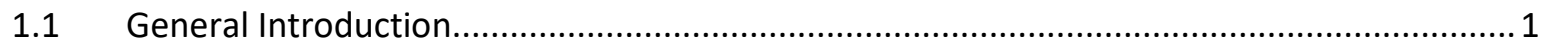

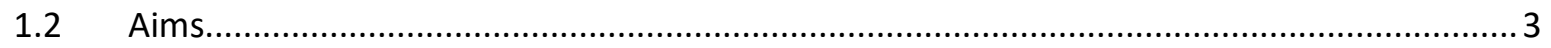

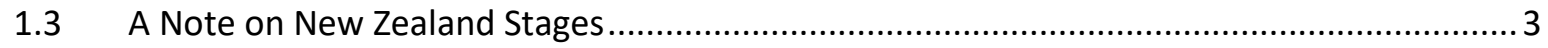

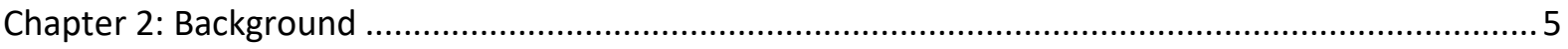

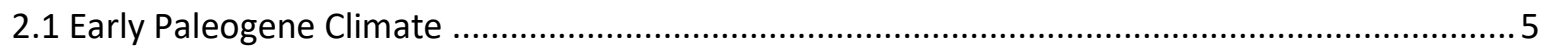

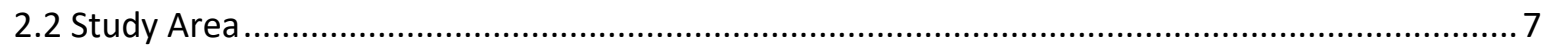

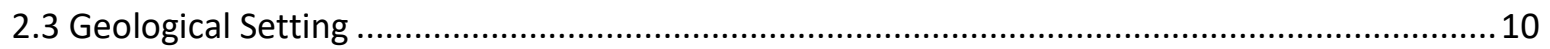

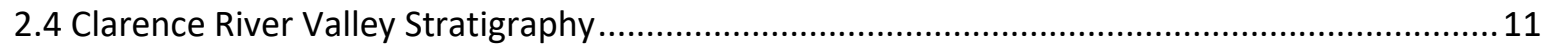

2.5 Paleoclimate Study at Mead Stream: Implications of Marl Deposition...................................... 14

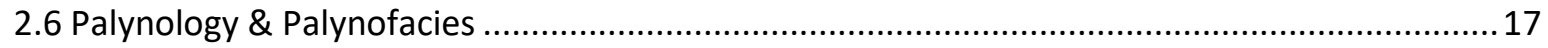

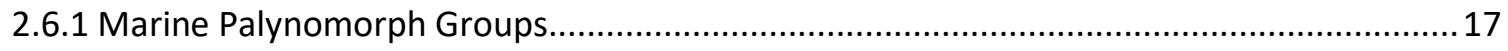

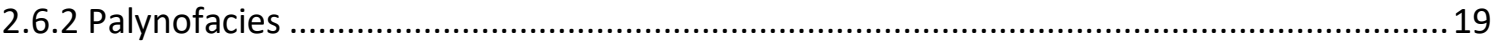

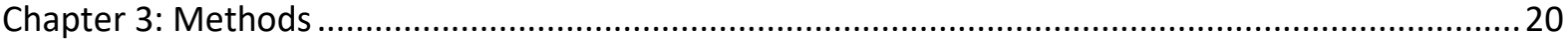

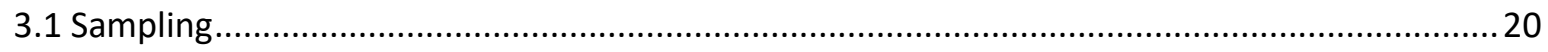

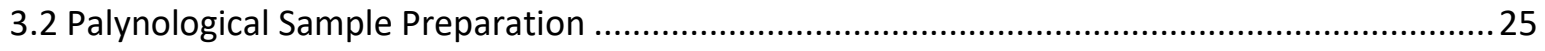

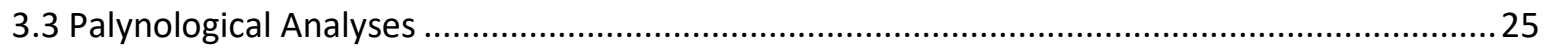

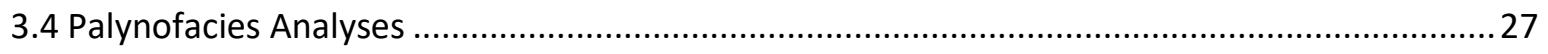

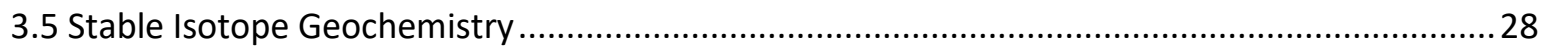

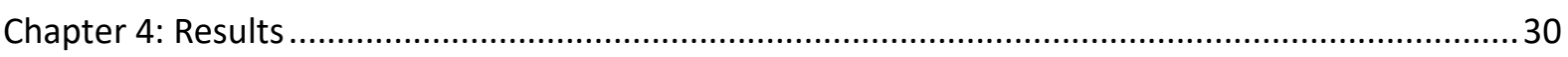

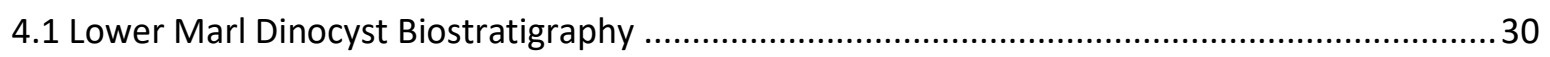

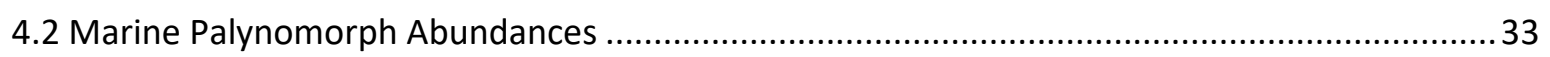

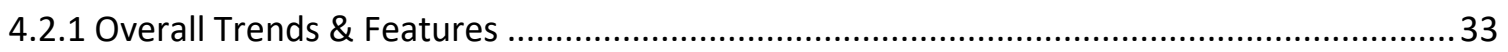

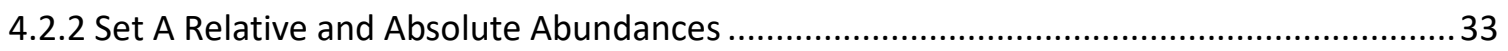

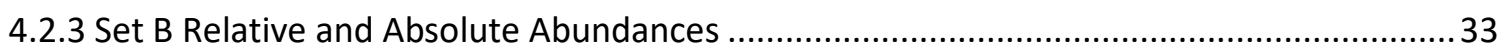

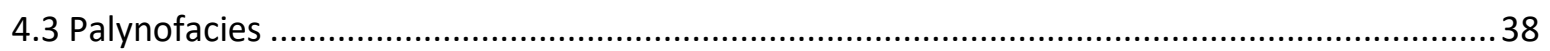

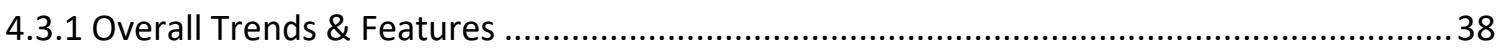

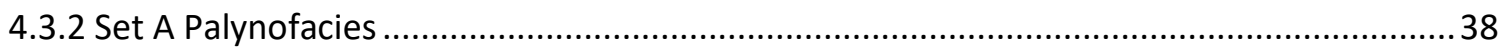

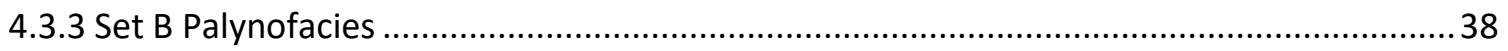

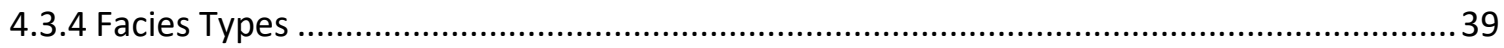

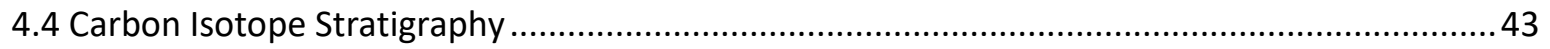

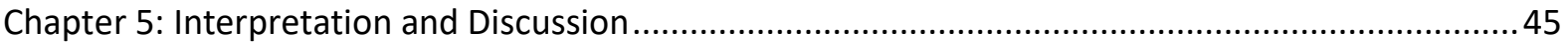




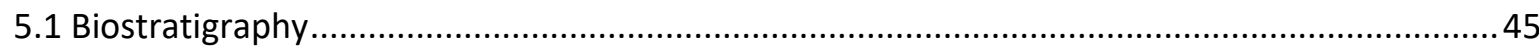

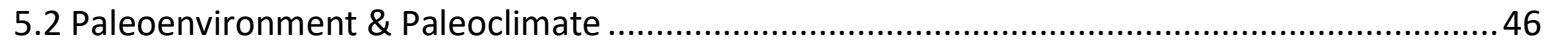

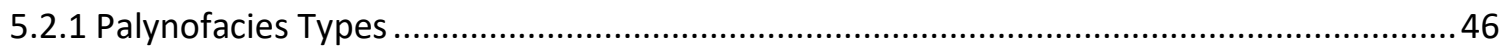

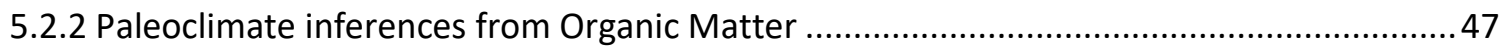

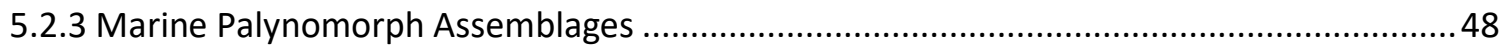

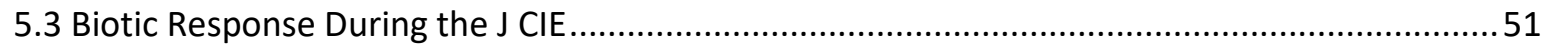

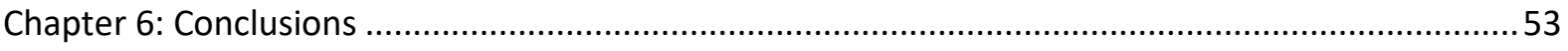

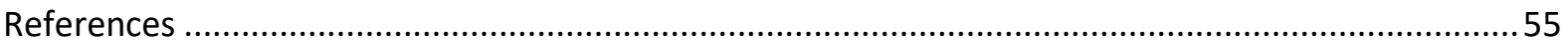

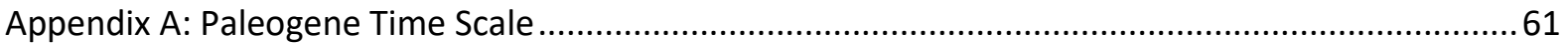

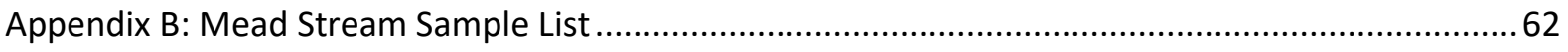

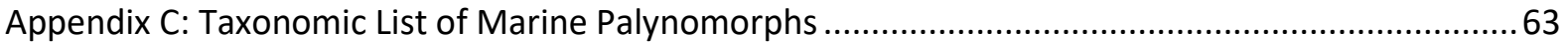

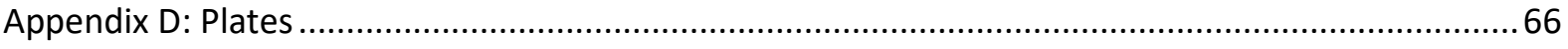

Appendix E: Taxonomic Occurrences, Counts \& Abundance.............................................................. 88

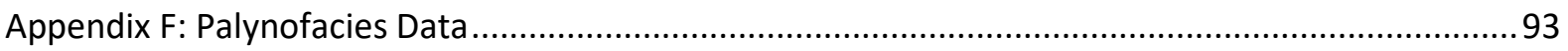




\section{Table of Figures}

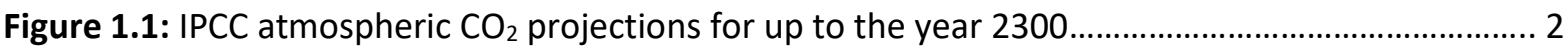

Figure 1.2: Multiproxy atmospheric $\mathrm{pCO}_{2}$ reconstruction for the Cenozoic ......................................2

Figure 1.3: Simplified geological map of southeastern Marlborough..................................................... 4

Figure 2.1: Ocean Drilling Program site $1262 \delta^{13} \mathrm{C}$ time series matched to the global splice of Cramer (2003)

Figure 2.2: The Lower Marl section at Mead Stream...............................................................................8

Figure 2.3: Mead Stream before and after the 7.8 Kaikoura Earthquake, November 2016...............9

Figure 2.4: Early Eocene paleogeographic reconstruction of New Zealand region........................... 11

Figure 2.5: Lithofacies trends within Muzzle Group strata in the Clarence River Valley. .................122

Figure 2.6: Magnetostratigraphy, and calcareous nannofossil biostratigraphy of Amuri Limestone at Mead Stream

Figure 2.7: Bulk carbonate $\delta^{13} \mathrm{C}$ record for Mead Stream, correlated to Ocean Drilling Program site 1262, and Deep Sea Drilling Project site 577.

Figure 2.8: Age-depth model, and derived sediment accumulation rates (SARs) for Mead Stream. .. 16

Figure 2.9: Dinoflagellate life cycle \& excystment............................................................... 18

Figure 2.10: Prasinophyte algae lifecycle. ............................................................................. 19

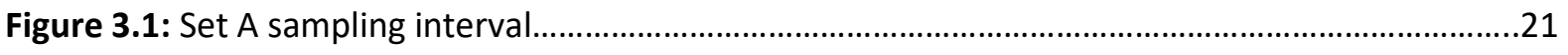

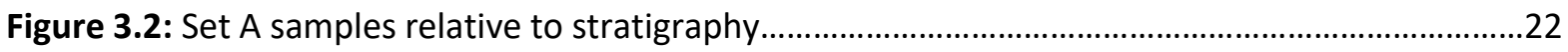

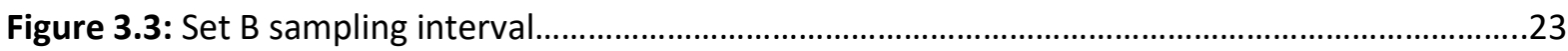

Figure 3.4: Set B samples relative to stratigraphy..................................................................................24

Figure 4.1: New Zealand dinocyst zonation, and LOs of key dinocyst taxa from the Lower Marl, Mead

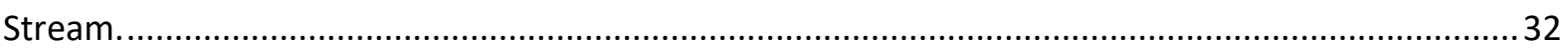

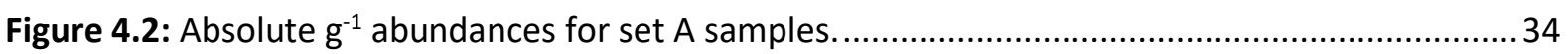

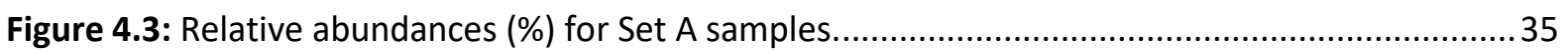

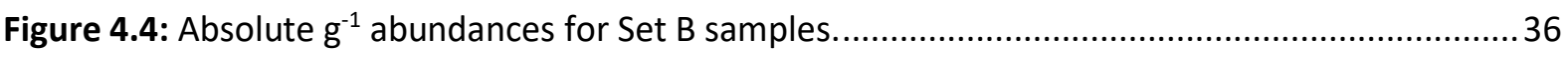

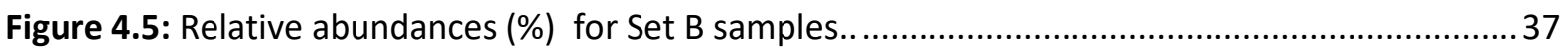

Figure 4.6: Relative abundances (\%) of organic matter types for Set A samples.............................40

Figure 4.7: Relative abundances (\%) of organic matter types for Set B samples............................. 41

Figure 4.8: Total distribution of palynofacies data ................................................................4 42

Figure 4.9: Bulk carbonate $\delta^{13} \mathrm{C}$ carbon isotope stratigraphy for the undeformed section of the Lower Marl, Mead Stream..................................................................................................4

Figure 5.1: Schematic model for the distribution of G-cyst dinocysts along a proximal-distal transect. 


\section{Chapter 1: Introduction}

\subsection{General Introduction}

The Intergovernmental Panel on Climate Change (IPCC) "business as usual" projections estimate atmospheric partial pressure of $\mathrm{CO}_{2}\left(\mathrm{pCO}_{2}\right)$ will peak at $\sim 2000$ ppmv during the $23^{\text {rd }}$ century if present rates of anthropogenic greenhouse gas emissions are not significantly altered (Collins et al., 2013) (Fig. 1.1). In order to better understand the effects such an increase in atmospheric $\mathrm{pCO}_{2}$ may have on future global climate systems it is important to study comparable climates in Earth's history and how those climates have previously responded under similar conditions.

The early Paleogene, and in particular the early Eocene (56.0-47.8 Ma), was the most recent time in Earth's history when atmospheric $\mathrm{pCO}_{2}$ was comparable to the peak levels of 2000 ppmv that have been forecast (Zachos et al., 2008) (Fig. 1.2). During this time "greenhouse" conditions (little or no permanent polar ice) prevailed and mean global temperatures were $8-12^{\circ} \mathrm{C}$ warmer than present day (Zachos et al., 2008). The Early Eocene Climatic Optimum (EECO), between $~ 53-50 \mathrm{Ma}$, represents a period of highest atmospheric $\mathrm{pCO}_{2}$ and maximum long-term temperatures for the early Paleogene (Zachos et al., 2001). The onset of the EECO is also punctuated by several negative carbon isotope excursions (CIES); transient decreases in $\delta^{13} \mathrm{C}$ records interpreted to reflect short-term hyperthermal events. These CIEs are superimposed over the period's long-term warming trend and are believed to have been triggered by rapid and massive influxes of isotopically light carbon into the oceanatmosphere system (Cramer et al., 2003, Galeotti et al., 2010, Zachos et al., 2010). It has been suggested that warming in response to carbon input during the EECO possibly initiated earlier in the marine record ( $\sim 33.3 \mathrm{Ma}$ ) than the terrestrial record ( $\sim 2 \mathrm{Ma})$, which would imply initial change leading to long-term warming commenced in the oceans (Hyland et al., 2017). Additionally, oceanographic circulation models suggest as much as $80 \%$ of heat transport occurred in the Pacific Ocean during the Eocene, hence studying sites from the Pacific region is of particular importance with respect to understanding Eocene climate dynamics (Huber and Sloan, 2001, Littler et al., 2014). 
Figure 1.1: IPCC atmospheric $\mathrm{CO}_{2}$ model projections for up to the year 2300. RCP 8.5 (red) represents the "business as usual" emissions scenario. Diagram modified from Collins et al. (2013)

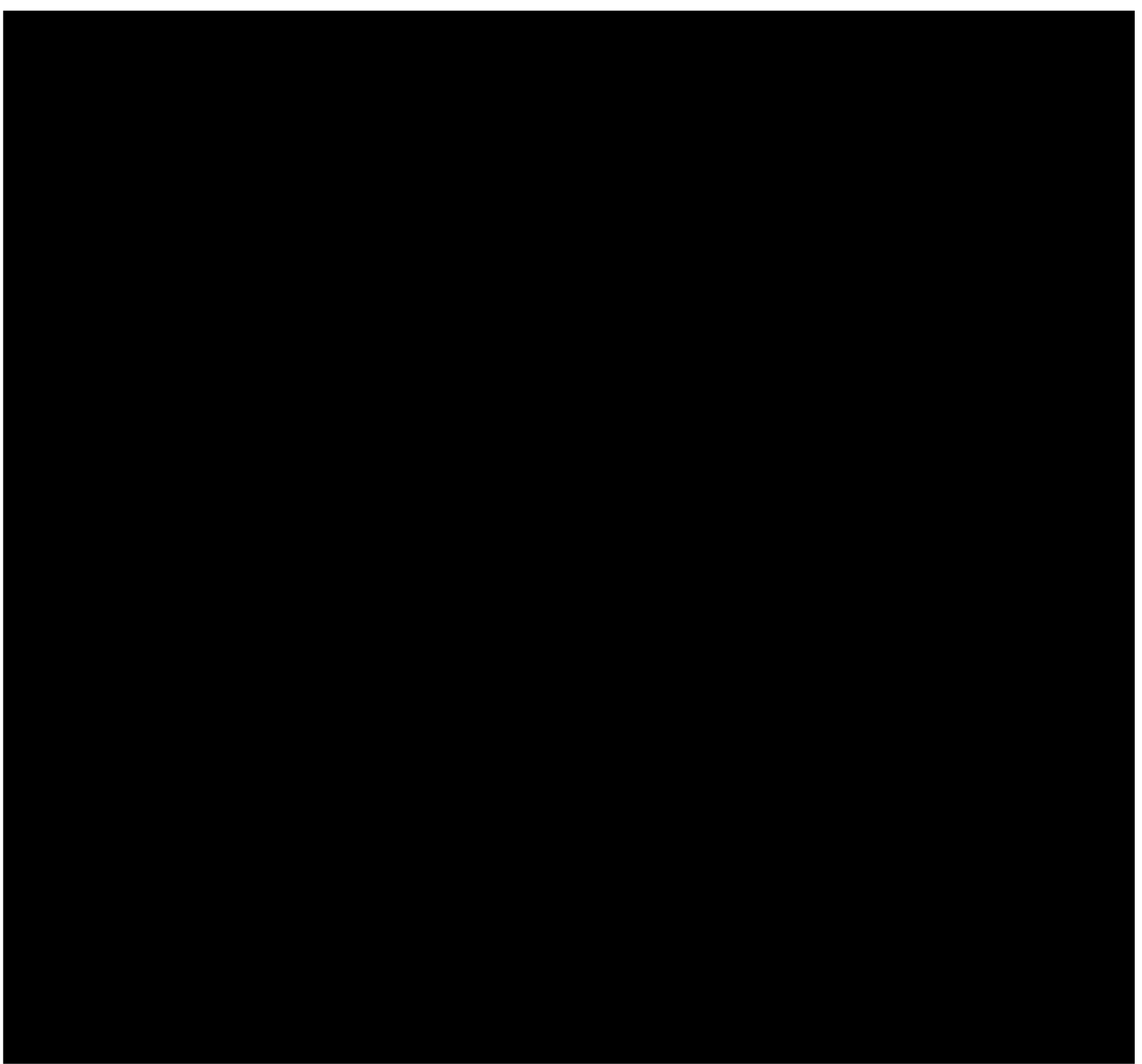

Figure 1.2: a, Multiproxy atmospheric $\mathrm{pCO}_{2}$ reconstruction for the Cenozoic. $\mathbf{b}$, Cenozoic climate curve from stacked deep-sea benthic foraminiferal oxygen-isotope curves, based on records from Deep Sea Drilling Project and Ocean Drilling Program sites. Note atmospheric $\mathrm{pCO}_{2}$ levels $>2000$ ppmv during the EECO. Diagram modified from Zachos et al. (2008). 
Expanded late Cretaceous-middle Eocene marine sequences exposed in the Clarence River Valley, southern Marlborough (Fig. 1.3), provide an excellent opportunity to study early Paleogene climate and the EECO in a mid-high latitude southwest Pacific setting. In the Clarence River valley the early Eocene is stratigraphically represented by alternating beds of micritic limestone and marls rich in terrigenous clay that comprise the uppermost Lower Limestone unit, and the Lower Marl unit (see section 2.4; Strong et al., 1995). The thickest and most complete section of early Eocene strata in Clarence Valley outcrops at Mead Stream - the site for this study.

Mead Stream was the site for several early Paleogene paleoclimate studies based on sedimentological and geochemical proxies due to its expanded and continuous stratigraphy combined with its relatively good accessibility. The section is known to be rich in marine microfossils - with several previous studies examining fossil foraminiferal, radiolarian, and calcareous nannofossil contents-and provides one of the best magnetostratigraphically controlled Eocene sections in New Zealand (Hollis, 2006, Dallanave et al., 2015, Strong et al., 1995). Despite this, fossil organic walled dinoflagellate cyst (dinocyst) research across the Lower Marl has been restricted to the reconnaissance study by Strong et al. (1995). Further study into dinocysts at Mead Stream is merited as they have proven utility both biostratigraphically, and as paleoclimate and paleoenvironment indicators; the in depth study of fossil algae and plankton allows insight into oceanographic change, as well as the biotic response to high atmospheric $\mathrm{pCO}_{2}$ forced climates in epicontinental settings.

\subsection{Aims}

This study investigates the palynology of the Lower Marl at Mead Stream. The objectives of the study are to:

1) Improve the resolution of dinocyst biostratigraphy across the early Eocene at Mead Stream.

2) Construct a paleoenvironmental history across the onset of the EECO at Mead Stream based on palynological assemblages and determine if there is evidence of climate cyclicity within the limestone-marl alternations of the Lower Marl.

3) Examine for evidence of enhanced deposition of terrigenous organic matter during deposition of marl beds using palynofacies analysis.

\subsection{A Note on New Zealand Stages}

Lithostratigraphic and biostratigraphic units from the wider study are often described, and correlated to the global timescale using the stages of the New Zealand Geological Timescale 
(Raine et al., 2015). Recognised Paleogene New Zealand stages and their 2015 age calibrations are presented in appendix $\mathrm{A}$.

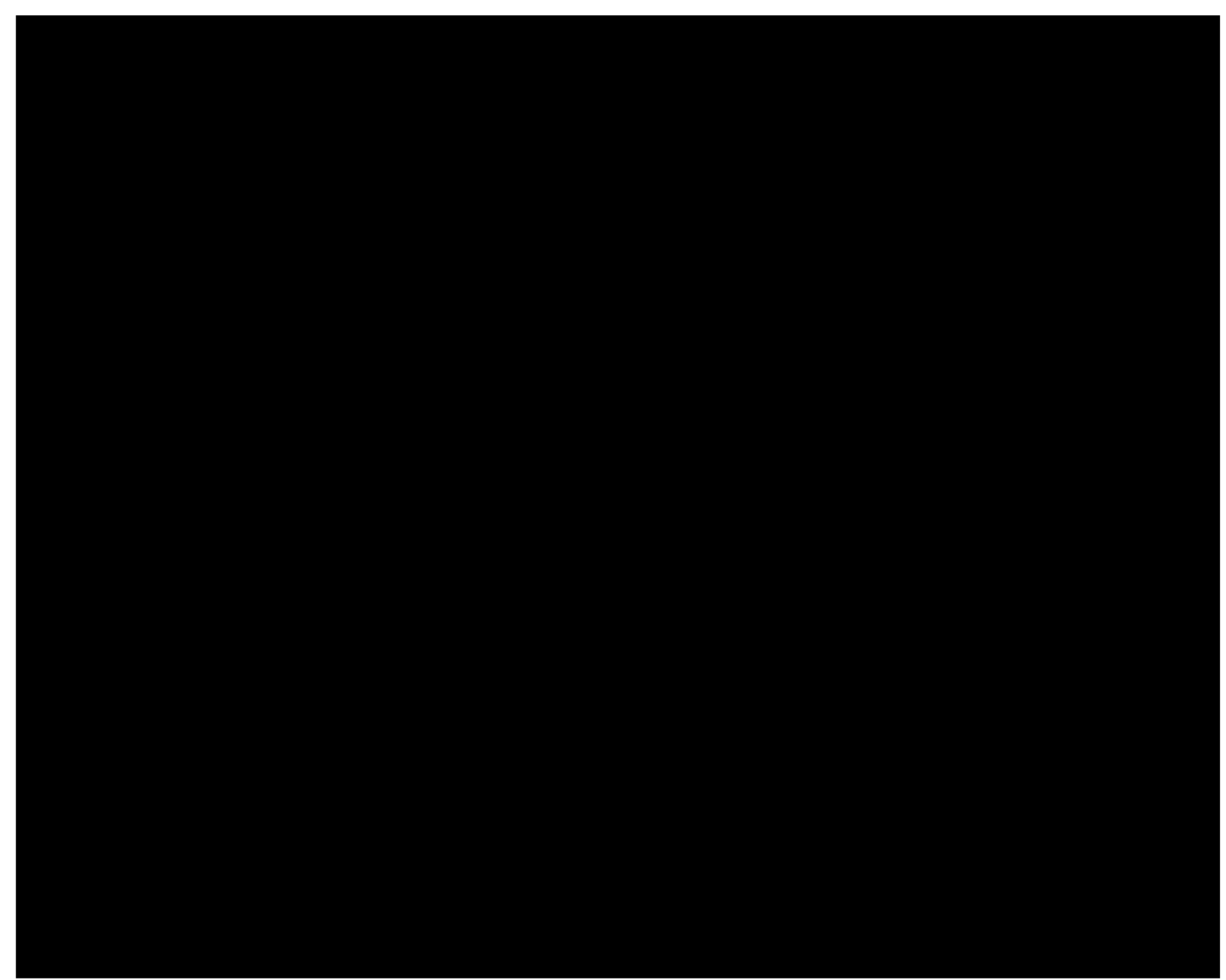

Figure 1.3: Simplified geological map of southeastern Marlborough. Grid coordinates are derived from the New Zealand 1:50,000 topographic map P30 (Clarence, NZMS 260). Key locations shown include Mead Stream, with age-equivalent sections at mid-Waipara River (MW) and Tawanui (TW) shown on the inset map. Image modified from Hollis et al. (2005a). 


\section{Chapter 2: Background}

\subsection{Early Paleogene Climate}

The "greenhouse" climate of the late Paleocene-early Eocene is characterized by significantly warmer mean global temperatures than the present day $\left(>8^{\circ} \mathrm{C}\right)$, and atmospheric $\mathrm{pCO}_{2}$ potentially in excess of 2000 ppmv (Zachos et al., 2008) (Fig 1.2). Mean annual air temperatures at this time are estimated to have reached $\sim 25^{\circ} \mathrm{C}$ in the Northern Hemisphere (Inglis et al., 2017), and $20^{\circ} \mathrm{C}$ in the Southern Hemisphere, with near-tropical vegetation persisting as far south as the Wilkes Land margin of Antarctica (Contreras et al., 2013, Pancost et al., 2013). Models suggest the Pacific Ocean was responsible for as much as $80 \%$ of global ocean heat transport at this time (Huber and Sloan, 2001).

Global stable isotope records show a long-term trend of global warming initiating in the late Paleocene ( $58 \mathrm{Ma}$ ) which reached a sustained period of peak global Paleogene temperatures of about $12^{\circ} \mathrm{C}$ warmer than present day during the EECO ( 53-50 Ma) (Zachos et al. 2001; Zachos et al. 2008) (Fig. 1.2). The duration of the EECO is broadly defined by contemporaneous shifts in deep-sea benthic foraminiferal isotope records: a positive shift in the $\delta^{18} \mathrm{O}$ record, and a negative shift in the $\delta^{13} \mathrm{C}$ record (Zachos et al. 2001). Peak EECO temperatures may have persisted for longer ( $52-49 \mathrm{Ma})$ in the southwest Pacific; this duration is broadly equivalent to the Mangaorapan Stage (Hollis et al., 2012). Based on a multiproxy comparison of early Eocene marine and terrestrial records, Hyland et al. (2017) suggested the onset of warming during the EECO possibly initiated earlier in the marine record $(\sim 53.3 \mathrm{Ma})$ than the terrestrial record $(\sim 52 \mathrm{Ma})$. They speculate the lag in the terrestrial record could be due to the initial reorganisation of oceanic carbon reservoirs, which in turn led to carbon concentrations in surface oceans exceeding buffering capacity, and subsequent injections of carbon into the atmosphere.

The long-term warming trend is punctuated by several transient hyperthermal events (Zachos et al. 2010) (Fig. 2.1). These events have been identified from sedimentary records as rapid, negative shifts in $\delta^{13} \mathrm{C}$ (carbon isotope excursions; CIEs), and are interpreted to have resulted from rapid release of carbon into the atmosphere resulting in high $\mathrm{pCO}_{2}(\mathrm{Cramer}$ et al. 2003; Zachos et al. 2010). The source of the implied injection of ${ }^{13} \mathrm{C}$-depleted carbon is debated; the more prominent propositions include seafloor methane release (Dickens, 2011) 
and organic matter oxidation relating to permafrost thawing (DeConto et al., 2012). These CIEs appear to be paced by Milankovitch cycles: principally the $405 \mathrm{kyr}$ and $100 \mathrm{kyr}$ eccentricity cycles (Zachos et al. 2010, Littler et al., 2014). Transient warming during CIEs is estimated to have been $\sim 2^{\circ} \mathrm{C}$ above background temperatures (Lauretano et al., 2015). The most pronounced of these CIEs - the Paleocene-Eocene Thermal Maximum (PETM; 55 $\mathrm{Ma}$ )-saw warming of $5-8^{\circ} \mathrm{C}$ above background temperatures across a 150-200 kyr period (Sluijs et al., 2006). The occurrence of the PETM is possibly out of phase with the other CIEs, suggesting the PETM is somewhat unique, as a mechanism other than orbital forcing may be required to account for its notable magnitude (Zachos et al. 2010).

Sea temperature reconstructions for the southwest Pacific during the EECO-based on estimates from both $\mathrm{Mg} / \mathrm{Ca}$ ratios and $\mathrm{TEX}_{86}$-indicate peak sea surface temperatures (SSTs) ranged from $25-29^{\circ} \mathrm{C}$, while peak sea floor temperatures were $\sim 20^{\circ} \mathrm{C}$ (Hines et al., 2017, Hollis et al., 2012). Minimal SST variability across subequatorial-subpolar paleolatitudes suggests an absent or very weak meridional temperature gradient across the Pacific region (Bijl et al., 2009, Hines et al., 2017). Hines et al. (2017) attribute such a southward extension of tropical sea temperatures during the EECO to an intensification, and southward propagation of a proto-East Australian Current.

Climate model simulations indicate the global hydrological cycle intensifies and moisture transport from low-high latitudes increases in response to global warming (Murphy et al., 2004, Meehl et al., 2007a, Meehl et al., 2007b, Held and Soden, 2006). These models imply precipitation at mid-high latitudes likely became more intense, but also more seasonal during the EECO. 
Figure 2.1: Ocean Drilling Program site $1262 \delta^{13} \mathrm{C}$ time series matched to the global splice of Cramer et al. (2003). Points labelled A-K represent globally recorded carbon isotope excursions (CIEs). Image from Zachos et al. (2010).

\subsection{Study Area}

The Clarence River valley is located between the Kaikoura Ranges in the south eastern Marlborough region (Fig. 1.3). Along the north eastern side of the river valley is the Chalk Range: a $\sim 35 \mathrm{~km}$ northeast-southwest strike ridge consisting of strata dipping $\sim 50^{\circ}$ to the northwest. Several sections outcrop through gorges incised through the Chalk Range approximately perpendicular to strike by a series of southeast-flowing Clarence River tributaries between Bluff Stream and Mead Stream. This study focusses on the northernmost of this series of sections at Mead Stream (Fig. 2.2). Best access to Mead Stream is gained from Kekerengu via Coverham Station ( $15 \mathrm{~km}$ inland from Kekerengu), although the section is presently inaccessible due to extensive landslides and rock falls as a result of the Kaikoura earthquake in November 2016 (Fig. 2.3). Mead Stream is situated on the privately held Bluff Station; hence, landowner's permission is required to visit the area. 


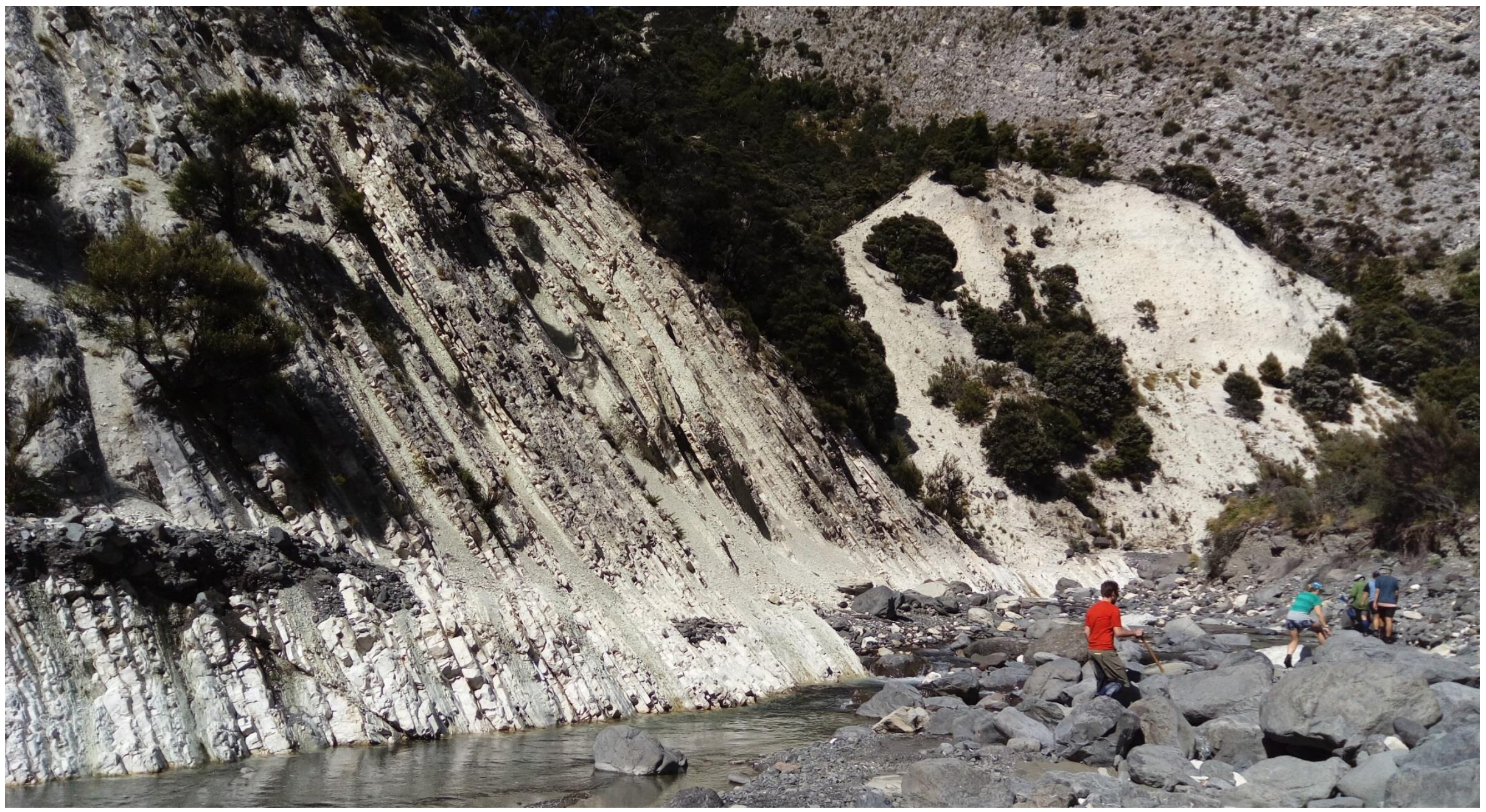

Figure 2.2: the Lower Marl section at Mead Stream. 


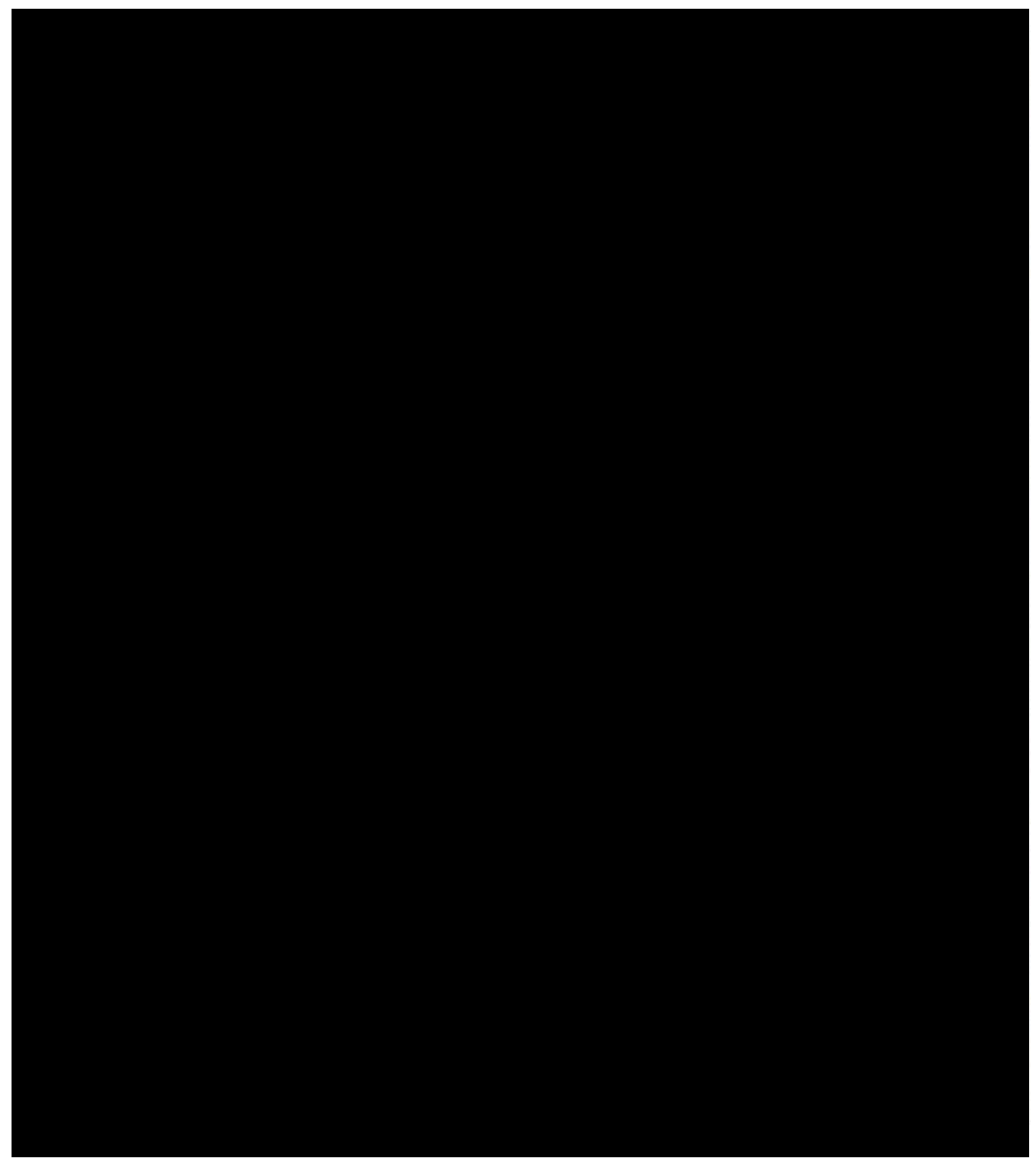

Figure 2.3: A, Mead Stream from December 2015, B, Mead Stream shortly after the 7.8 Kaikoura Earthquake, November 2016. Note the formation of several large lakes and several large landslides on the southern bank. Images from Google Earth. 


\subsection{Geological Setting}

During the late Cretaceous-middle Eocene the Zealandia continent was situated at a paleolatitude of about $50-65^{\circ} \mathrm{S}$ (Crampton et al., 2003) (Fig. 2.4). At this time several sedimentary basins formed and deepened around New Zealand during a period of passive margin thermal subsidence (King, 1999). Sedimentary strata of this age exposed in present day Clarence River valley were deposited on the eastern margin of an embayment on New Zealand's northern paleo-margin (Fig. 2.4b). This paleo-embayment was situated between the East Coast Basin and the Chatham Rise, where pelagic-hemipelagic sediments were deposited on the outer shelf-upper slope of a carbonate platform; foraminiferal assemblages suggest deposition occurred at a water depth of $200-1000 \mathrm{~m}$ (Crampton et al., 2003, Hollis et al., 2005b, Strong et al., 1995). This platform was starved of terrigenous sediment, in contrast with the relatively siliciclastic-rich age-equivalent sediments deposited along the western margin of the paleo-embayment (Hines, 2012). The sections exposed between Bluff Stream and Mead Stream in the Chalk Range effectively present a shelf-slope depth profile deepening to the northeast (Reay, 1993, Hollis et al., 2005a). The Mead Stream section is the thickest of these exposures; the $~ 650 \mathrm{~m}$ thick near-continuous Muzzle Group sediments (see below) deposited between $~ 70-40 \mathrm{Ma}$ indicates greater and more continuous sedimentation occurred in upper slope settings on the Marlborough paleo-platform (Strong et al., 1995, Hollis et al., 2005b). Subsequent Neogene tectonic activity-associated with the propagation of the modern day Pacific-Australian plate boundary-resulted in the section being uplifted, rotated, and folded into its present day position on the northwest limb of the Ben More Anticline (Crampton et al., 2003). 


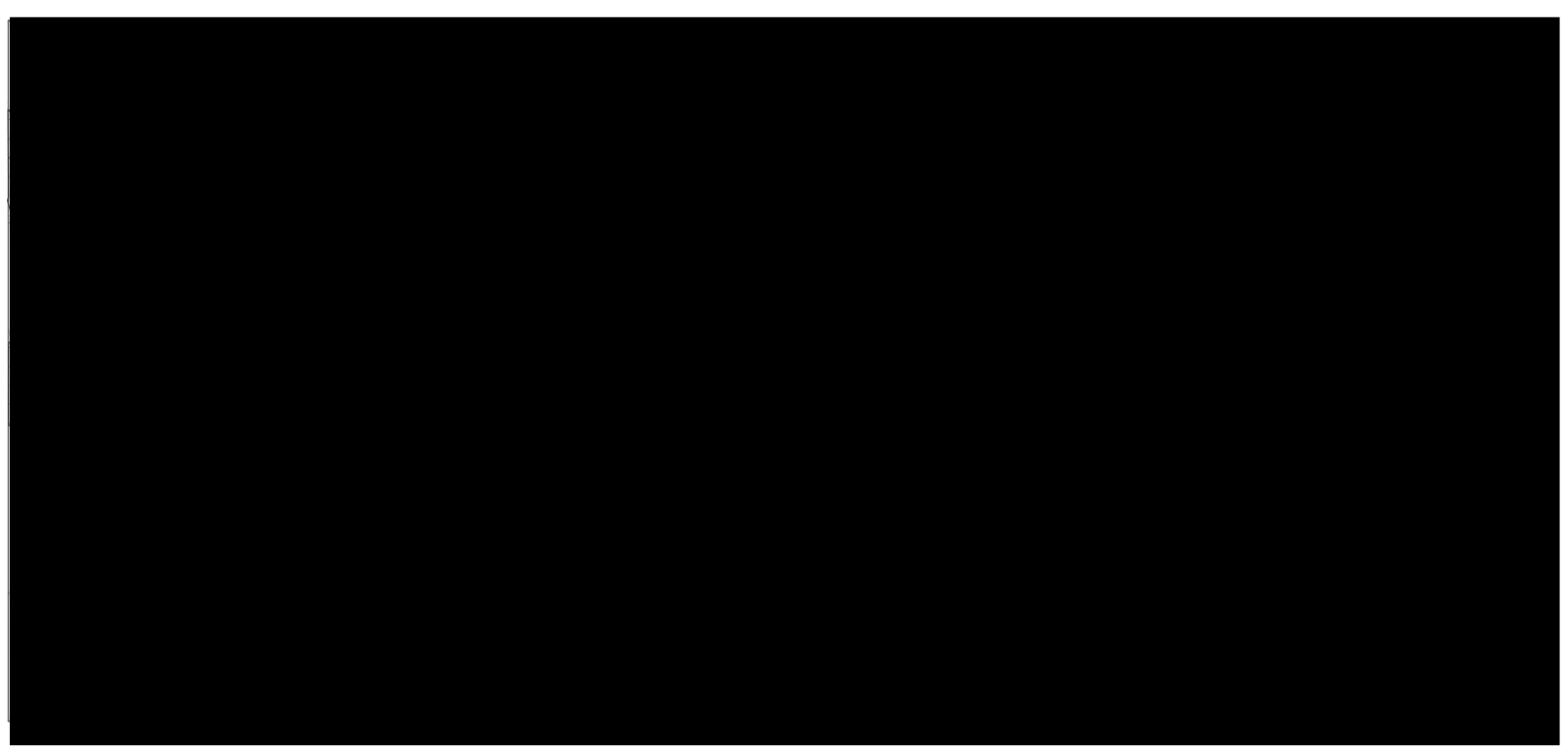

Figure 2.4: A, Early Eocene paleogeographic reconstruction of New Zealand region, showing sites at Mead Stream (red circle), mid-Waipara river (MW), and Tawanui (TW), B, close-up view of the Marlborough paleo-embayment. Images modified from Crampton et al. (2003), base paleogeographic map from King et al. (1999).

\subsection{Clarence River Valley Stratigraphy}

Strata in the Clarence River valley have been assigned to formal and informal stratigraphic units as presented in Figure 2.5. All stratigraphic depths reported herein, for which zero datum is set at the Cretaceous/Paleogene (K/Pg) boundary, refer to Mead Stream from the November 2015 version of GNS Science's Mead Stream stratigraphic log (J. Crampton, unpublished data).

The Muzzle Group consists of Late Cretaceous-middle Eocene strata comprising micritic limestones, smectitic marls, and cherts, derived from biogenic carbonate, terrigenous aluminosilicates, and biogenic silica (Reay, 1993, Strong et al., 1995). The Amuri Limestone formation within the Muzzle Group-and the unit of interest for this study-spans the upper Paleocene-middle Eocene (Dallanave et al., 2015). Other constituent units of the Muzzle group not relevant to this study are the upper Cretaceous-Paleocene Mead Hill Formation, and the upper Paleocene Waipawa Formation at Mead Stream, or equivalent Teredo Limestone to the south (Reay 1993, Hollis et al., 2005b).

Amuri Limestone is subdivided into four informal stratigraphic units. At Mead Stream these are well represented and have excellent age control from correlation of magnetostratigraphy and calcareous nannofossil biostratigraphy (Martini, 1971), as well as foraminiferal and radiolarian biostratigraphy (Hollis et al., 2005b, Dallanave et al., 2015) (Fig. 2.6). Names for 
these units are capitalised to distinguish them from lithological descriptions. These units are as follows from bottom to top:

Lower Limestone (115-205 m)

Mostly comprises dm-bedded, grey, siliceous limestones with a minor chert component separated by very thin $(<2 \mathrm{~cm})$ marl horizons or partings. Multiple prominent marl rich horizons have been identified within the Lower Limestone, the thickest of which is the $2.4 \mathrm{~m}$ thick Dee Marl. The Lower Limestone spans the late Teurian-late Waipawan stages.

Lower Marl (205-320 m)

Alternating soft, smectitic, grey-green marls and well indurated, micritic, white-grey limestones. Limestones contain internal $\mathrm{cm}-\mathrm{dm}$ scale bedding; this internal bedding is also present in some marl intervals in the lowermost part of the unit. Faulting and folding between 265-315 m ("deformed zone") interrupt the regular limestone-marl alternations and overall marl content increases. Lower contact with Lower Limestone is gradational between 192$205 \mathrm{~m}$ and the base of the Lower Marl is arbitrarily defined by the base of the lowermost marl interval. The Lower Marl spans the late Waipawan-earliest Heretaungan stages; the deformed zone broadly corresponds to the Mangaorapan Stage.

\section{Upper Limestone (320-397 m)}

Consists of dm-bedded, highly indurated white limestones with stylolitic partings. Base of this unit is defined by the top of the uppermost marl interval of the Lower Marl. The Upper Limestone approximately spans the Heretaungan-early Bortonian stages.

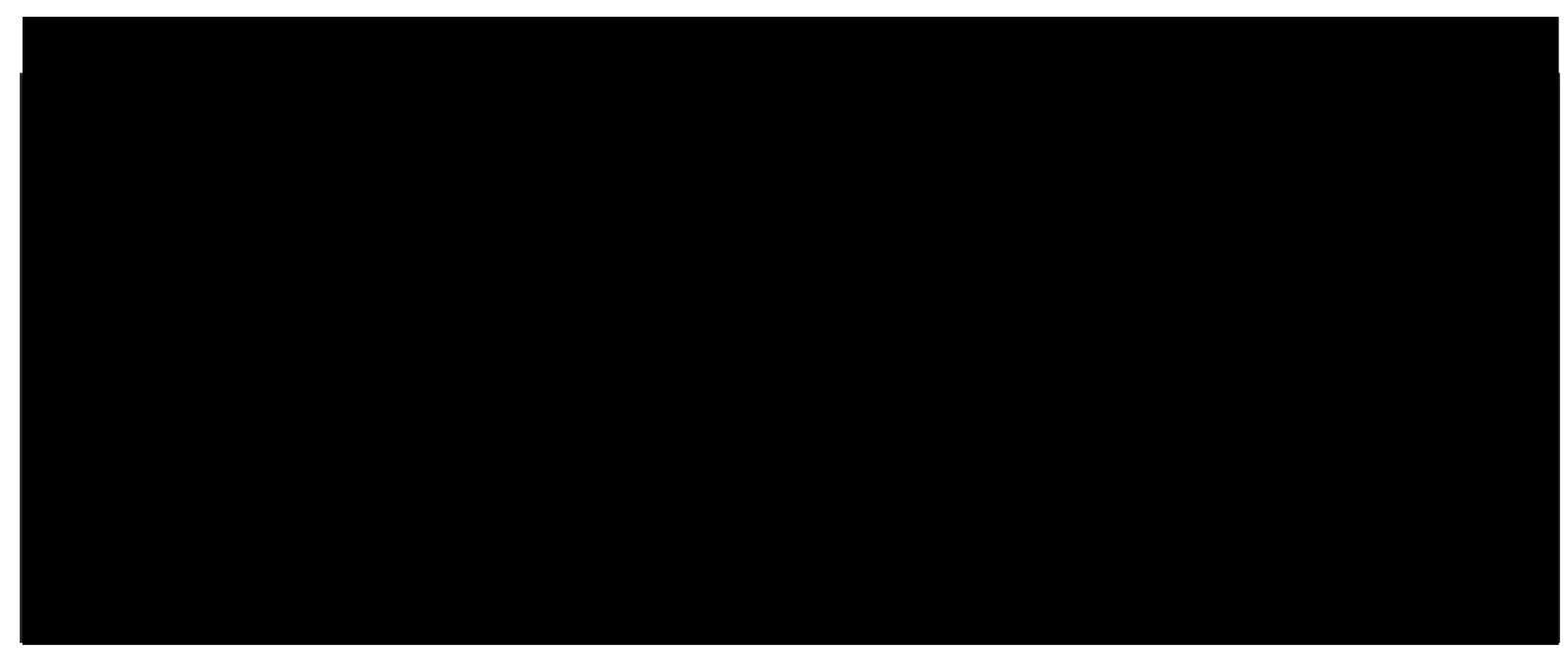

Figure 2.5: Lithofacies trends within Muzzle Group strata in the Clarence River Valley. Figure modified from Reay (1993). 
Upper Marl (397-523 m)

Grey-green smectitic marls with $\mathrm{cm}-\mathrm{dm}$ scale, interbedded, moderately indurated micritic limestone similar to the Lower Marl. Limestone comprises the minor lithological component of the Upper Marl. The lower contact of the Upper Marl is gradational and the base is arbitrarily defined as the base of the lowermost marl interval. The entirety of the unit occurs during the Bortonian Stage. The Upper Marl is uncomformably overlain by the early Miocene Weka Pass Formation and thus represents the uppermost extent of the continuous early Paleogene section in the Clarence River valley (Strong et al., 1995).

Figure 2.6: Magnetostratigraphy, and calcareous nannofossil biostratigraphy of Amuri Limestone at Mead Stream. Flgure modified from Dallanave et al. (2015). 


\subsection{Paleoclimate Study at Mead Stream: Implications of Marl Deposition}

Previous studies have highlighted the active role of climate evolution in the deposition of the Amuri Limestone at Mead Stream. The deposition of marl horizons rich in terrigenous clays has been attributed to the intensification of the hydrological cycle induced by climatic warming (e.g. Hollis et al., 2005b, Slotnick et al., 2012). Such warming likely caused reduced vegetative coverage, increased chemical weathering and erosion, and enhanced seasonal discharge of terrigenous material onto the continental shelf-slope, which in turn resulted in periods of carbonate dilution; this is reflected by the switch from limestone to marl deposition (Ludwig and Probst, 1998, Schmitz and Pujalte, 2003, Schmitz and Pujalte, 2007, Meehl et al., 2007a, Meehl et al., 2007b). This process of carbonate dilution and enhanced sedimentation during periods of warming at Mead Stream is in stark contrast with age-equivalent deep sea sites, where clay rich horizons deposited during warming and $\mathrm{CO}_{2}$ injection, are indicative of carbonate dissolution due to ocean acidification and a shoaling of the calcium compensation depth (Slotnick et al., 2012). Because of this, Mead Stream is an important early Paleogene section as intervals deposited under warmer climatic conditions in relatively shallow are expanded in comparison to equivalent deposits in deep sea settings.

Carbon isotope stratigraphy, and clay mineral content provide strong evidence of the relationship between climatic warming and marl deposition. Marl-dominant horizons within the Lower Limestone correspond to established CIEs (the PETM, H1 \& H2, I1 \& I2; Fig. 2.7)with the thickest of these horizons (the Dee Marl) corresponding to the PETM, and the Lower Marl (which represents a prolonged period of enhanced marl deposition) broadly corresponding to the EECO (Slotnick et al., 2012, Slotnick et al., 2015). Slotnick et al. (2012) define the EECO at Mead Stream as the interval spanning the J CIE (206.201 m; $53.35 \mathrm{Ma})$ to the Lower Marl/Upper Limestone contact (320 m; 49 Ma), suggesting the change from limestone-dominant to marl-dominant lithotypes, coupled with a long-term low in $\delta^{13} \mathrm{C}$ across this interval is reflective of long-term EECO climatic warming. The period of peak EECO temperatures in the southwest Pacific is broadly equivalent to the Mangaorapan Stage (5248.9 Ma) (Hollis et al., 2009, Hollis et al., 2012); at Mead Stream the Mangaorapan Stage is approximately represented by the period of greatest marl deposition and highest sedimentation rates, which corresponds to the deformed zone within the Lower Marl (Slotnick et al., 2015, Dallanave et al., 2015) (Fig. 2.8). Further to this, smectite, which is the 
dominant clay mineral in terrigenous fractions at Mead Stream, is known to be formed following an increase in chemical weathering under warmer, tropical-like humid conditions (Dallanave et al., 2015, Fagel, 2007). Marls typically contain higher quantities of smectite than limestones at Mead Stream. Radiolarian assemblages from the Lower Marl indicate a transition from cooler, more eutrophic conditions, to more stratified, oligotrophic, subtropical conditions as marl deposition increases (Hollis, 2006).

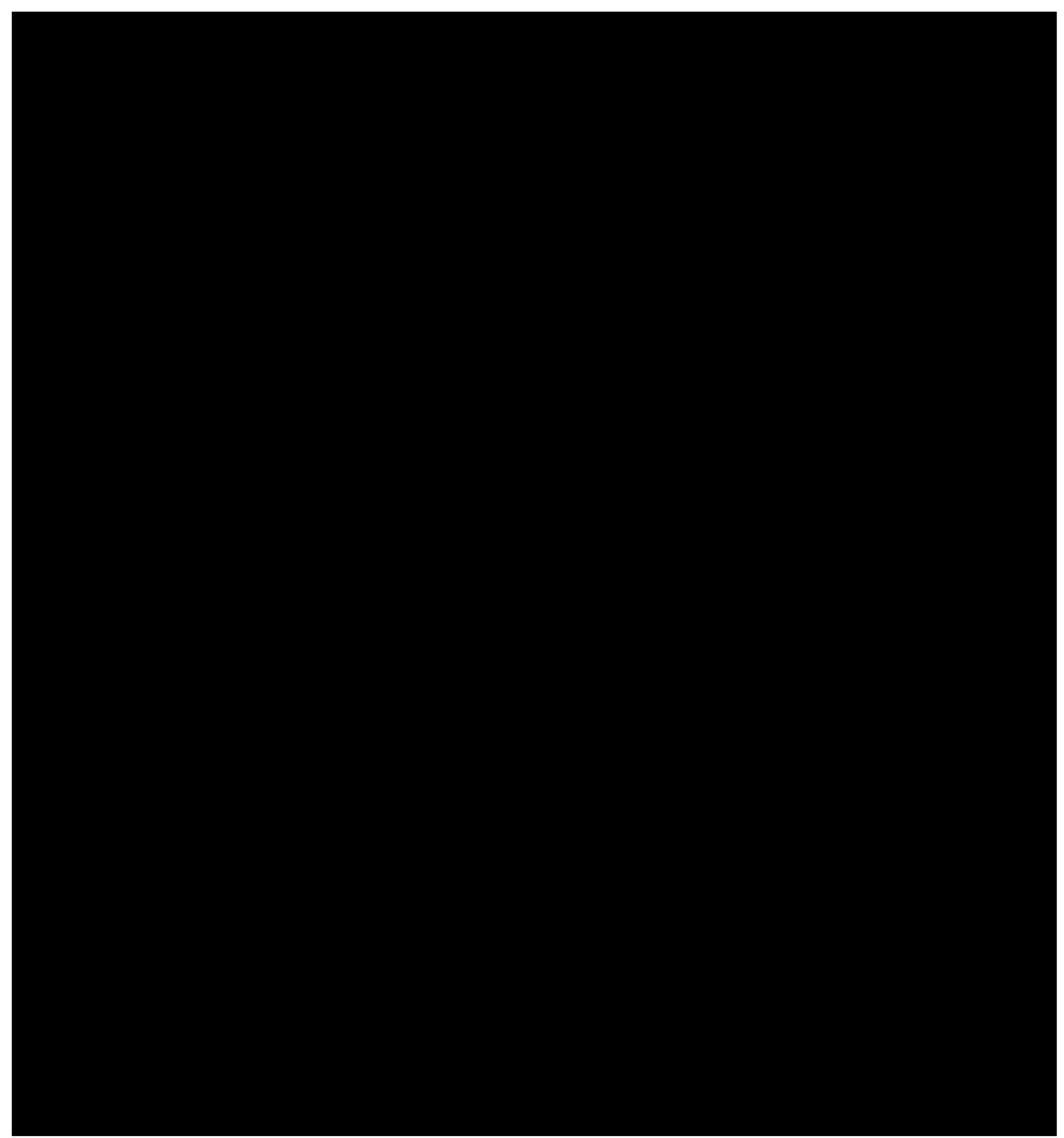

Figure 2.7: Bulk carbonate $\delta^{13} \mathrm{C}$ record for the upper Lower Limestone and Lower Marl at Mead Stream, correlated to Ocean Drilling Program site 1262, and Deep Sea Drilling Project site 577. Tan intervals represent CIEs. Note expanded CIE horizons at Mead Stream compared to deep water sites (1262 and 577). Figure from Slotnick et al. (2012). 


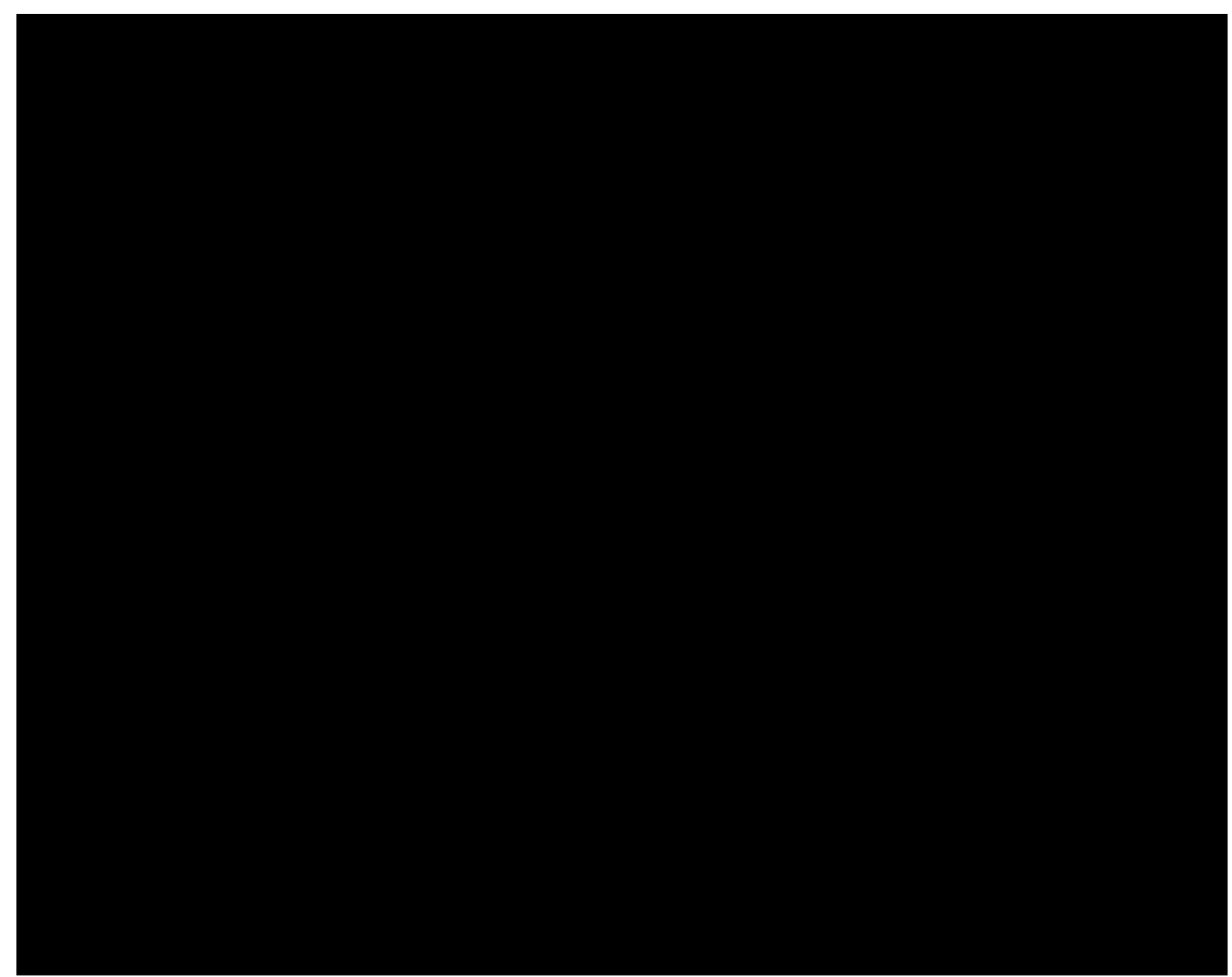

Figure 2.8: Age-depth model, and derived sediment accumulation rates (SARs) for Mead Stream. Light grey, dashed SARs represent unreliable values due to deformation. Image from Dallanave et al. (2015) 


\subsection{Palynology \& Palynofacies}

The primary focus of this study is the palynology of the Lower Marl at Mead Stream. Palynology is the study of plant pollen, spores and certain microscopic plankton organisms (collectively termed palynomorphs) in both living and fossil form.

\subsubsection{Marine Palynomorph Groups}

Palynormorphs - the primary focus of this study-are the acid insoluble remains of terrestrial or marine organisms. They are composed of decay-resistant organic substances (typically sporopollenin, dinosporin, or chitin) and hence are usually well preserved in the fossil record (Tappan, 1980). Two groups of marine palynomorphs have been identified at Mead Stream, these are:

\section{Dinoflagellate Cysts}

Dinoflagellates are a group of predominantly marine, planktonic, unicellular protists that derive their name from two flagella that facilitate cell motility (Evitt, 1985). They are present in a wide variety of environments and particularly abundant in neritic settings (Dale, 1996). During the dinoflagellate life cycle some species form thick-walled, hypnozygotic resting cysts (dinocysts), often in response to an environmental trigger such as temperature or nutrient supply (Evitt, 1985, Binder and Anderson, 1986) (Fig. 2.9). Following a favourable shift in environmental conditions the organism excysts, with the cyst settling as a sediment particle and fossilising; the motile stage does not usually preserve. The majority of cysts can be classified as either peridinioid (P) or gonyaulacoid (G) cysts based on cyst morphology: P-cysts are generally formed by heterotrophic dinoflagellates whereas G-cysts are generally formed by autotrophic dinoflagellates (Powell et al., 1992). 


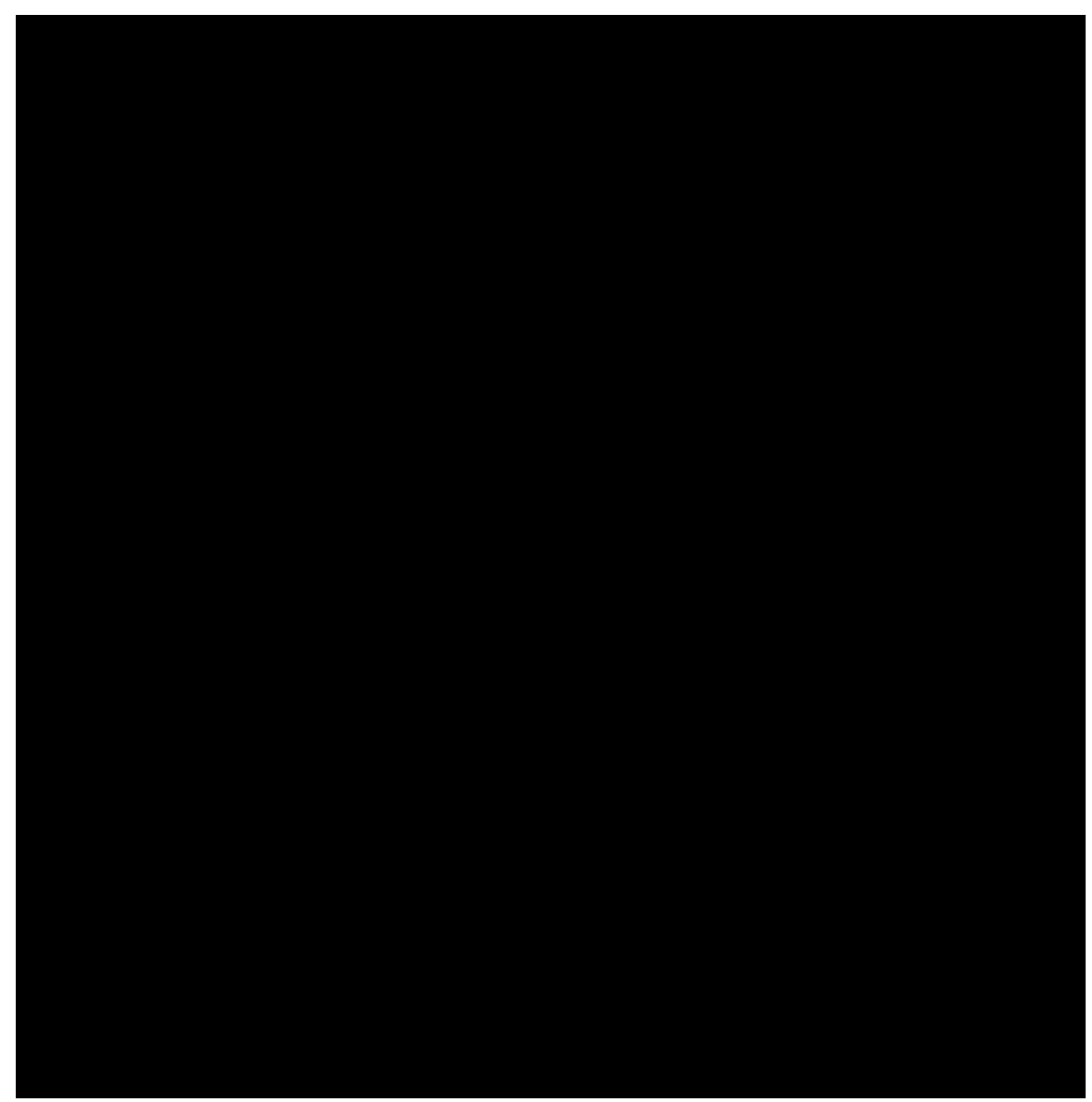

Figure 2.9: A, dinoflagellate life cycle, the cyst forming stage is highlighted, modified from MacRae et al. (1996), B, (1-6) time-series of dinoflagellate excystment, modified from Dale (2001). 


\section{Prasinophyte Algae}

Prasinophyte algae are a paraphyletic class of unicellular, chlorophyte green algae. Prasinophyte algae tend to be abundant in near-shore, brackish waters and can often occur as monospecific blooms (Leliaert et al., 2012). Prasinophyte algae are planktonic organisms with a life cycle consisting of a unicellular motile phase, and a non-motile resting phase called a phycoma (Mudie et al., 2011) (Fig. 2.10). Two types of fossilised prasinophyte phycomata are recognised in this study: a single species each of the genera Cymatiosphaera and Pterospermella.

\subsubsection{Palynofacies}

Palynofacies is the study of all acid resistant, microscopic particulate organic matter extracted from sediments. Observed variations in relative abundances can be used to make environmental and hydrographical interpretations in both terrestrial and shelf-slope marine environments (Tyson, 1995).

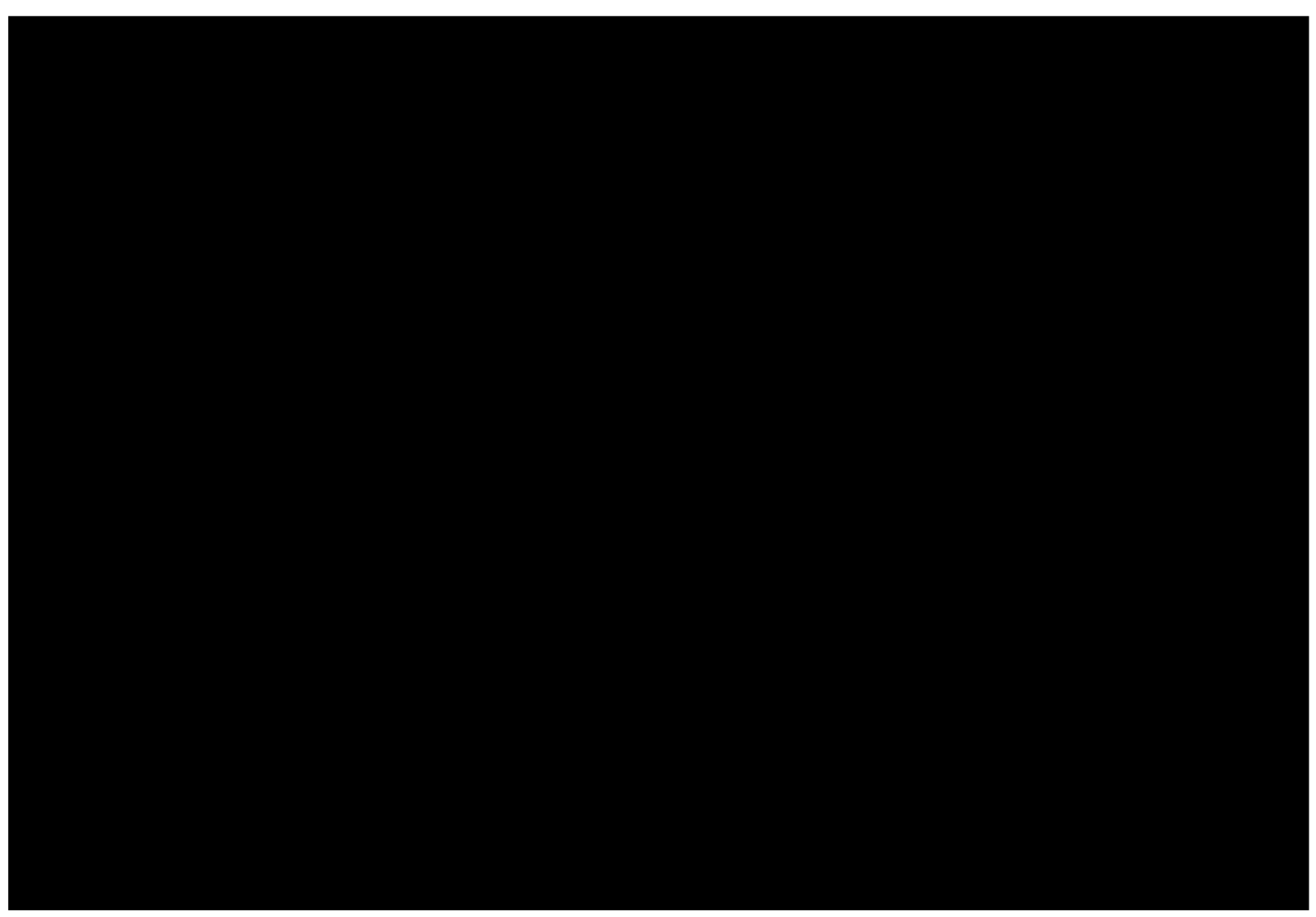

Figure 2.10: Prasinophyte algae lifecycle, modified from Martin (1993). 


\section{Chapter 3: Methods}

\subsection{Sampling}

Samples were collected from Mead Stream in December 2015. Seventy five high-resolution samples were collected from two intervals in the Lower Marl-named Set A and Set B-and are listed in appendix (B). Set A (204.715 m-207.900 m; Fig. 3.1) spans the base of the Lower Marl and comprises 51 samples (Fig. 3.2), while Set B (251.573 m-254.64 m; Fig 3.3) spans the Waipawan-Mangaorapan transition and comprises 24 samples (Fig. 3.4). These intervals were selected as they likely coincide with the onset of the EECO and the onset of peak EECO temperatures respectively (Hollis et al., 2012, Dallanave et al., 2015). Samples were collected by making initial incisions in the bedding with a rock saw, and then rock was broken loose using hammers and chisels. Sample spacing was defined by Internal bedding within limestone and marl couplets. Where no internal structure was present a representative sample from across the bed was collected. Samples were labelled and oriented. Sample names consist of a limestone bed number and a sequential number (e.g. L1/1); limestone bed numbers correspond to those from the GNS Science Mead Stream log (J. Crampton, unpublished data). Marl samples are denoted with an " $M$ " (e.g. L1/M/1). Interval thicknesses were measured using tape measures and subsequently calibrated to the Mead Stream log. Reported stratigraphic heights are for top surfaces of beds. 


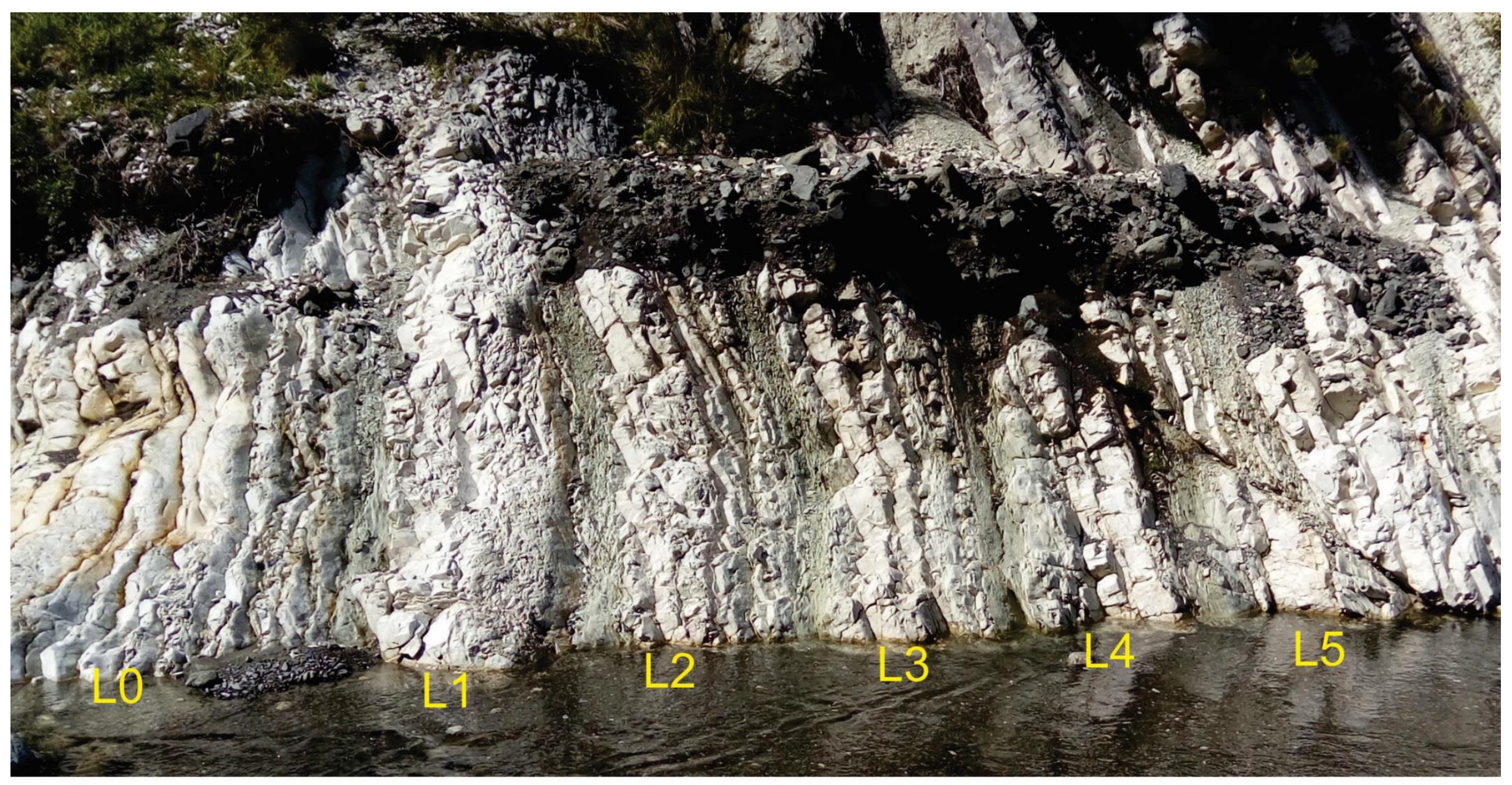

Figure 3.1: Set A sampling interval. Note top surface of $L 5$ contacts fault near the water surface. 


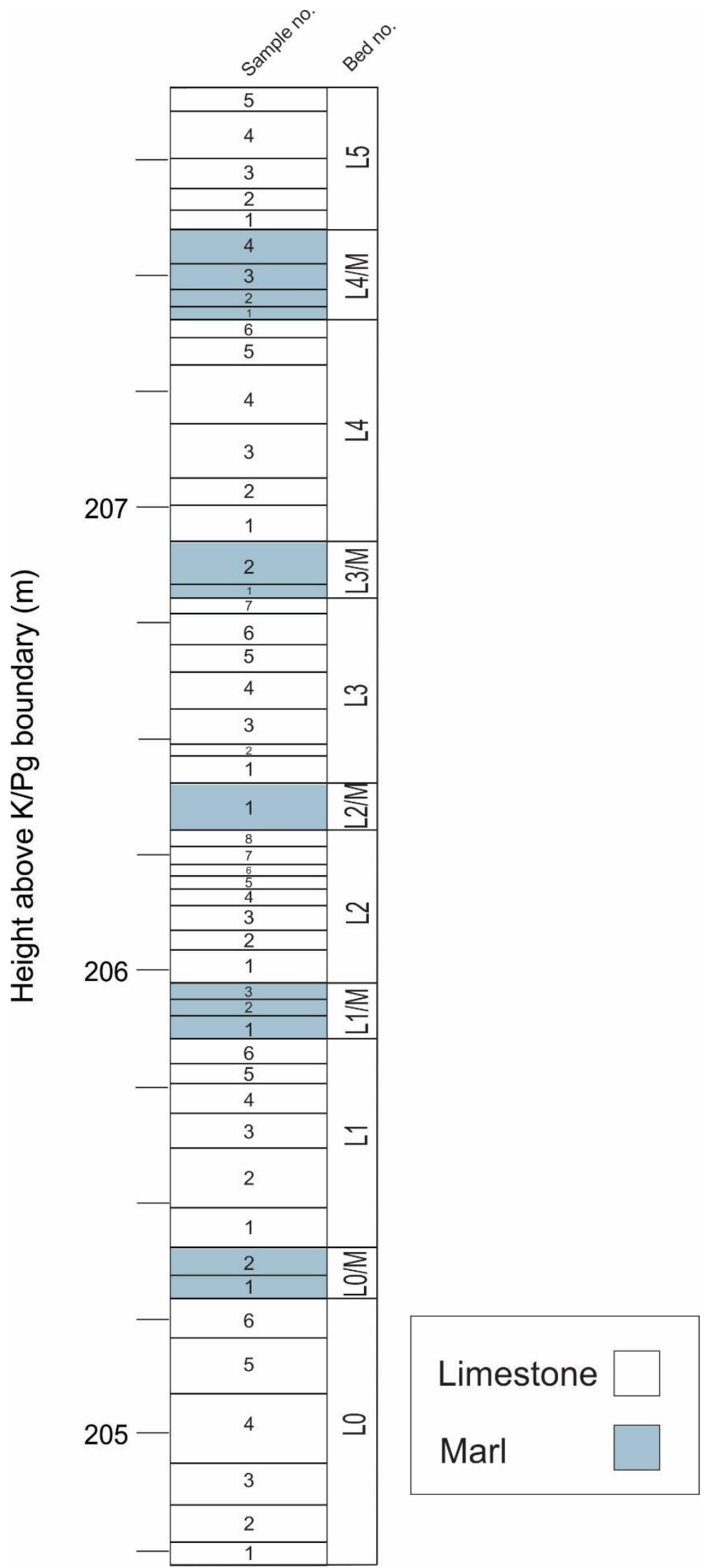

Figure 3.2: Set A samples relative to stratigraphy. 


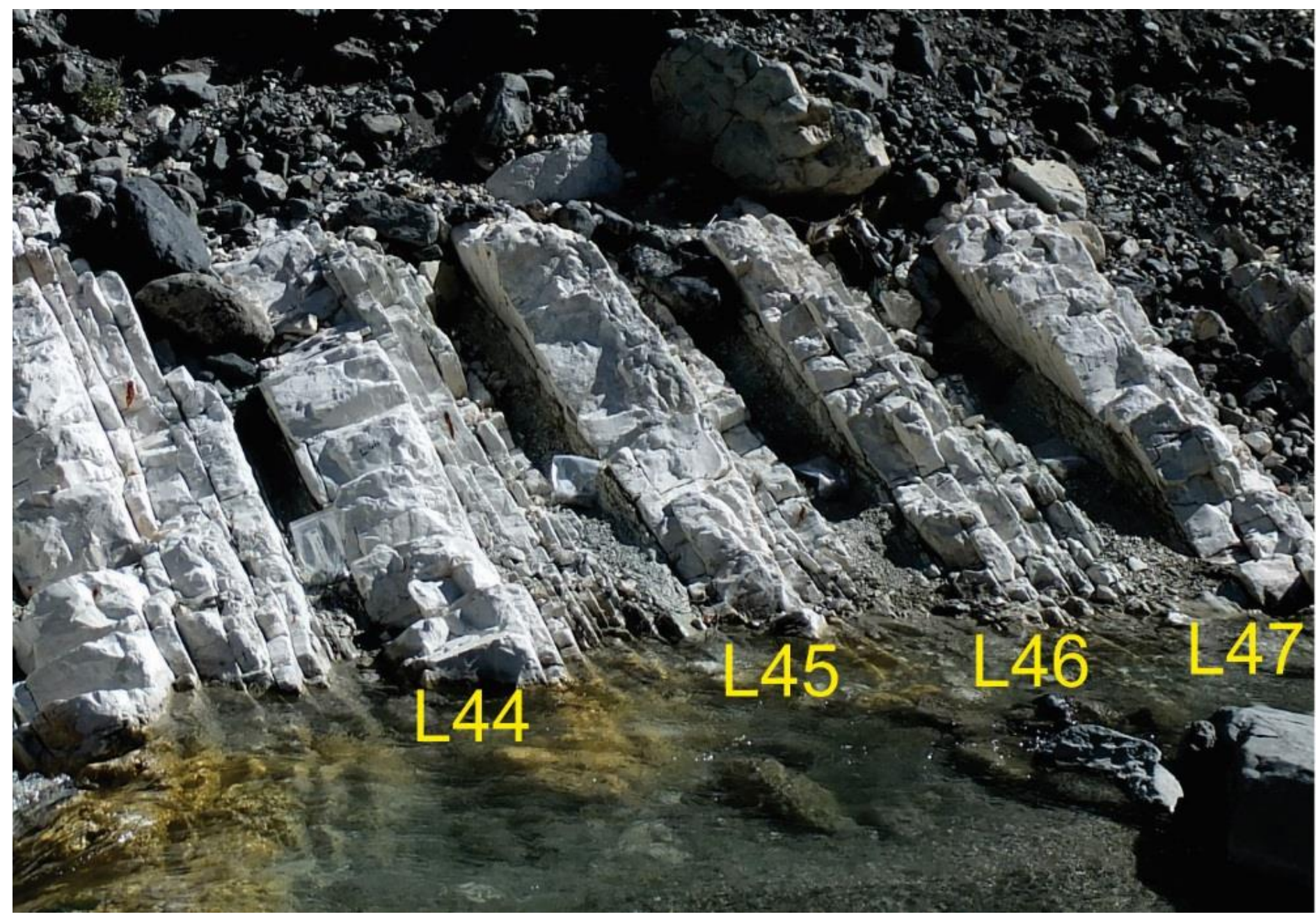

Figure 3.3: Set B sampling interval. 


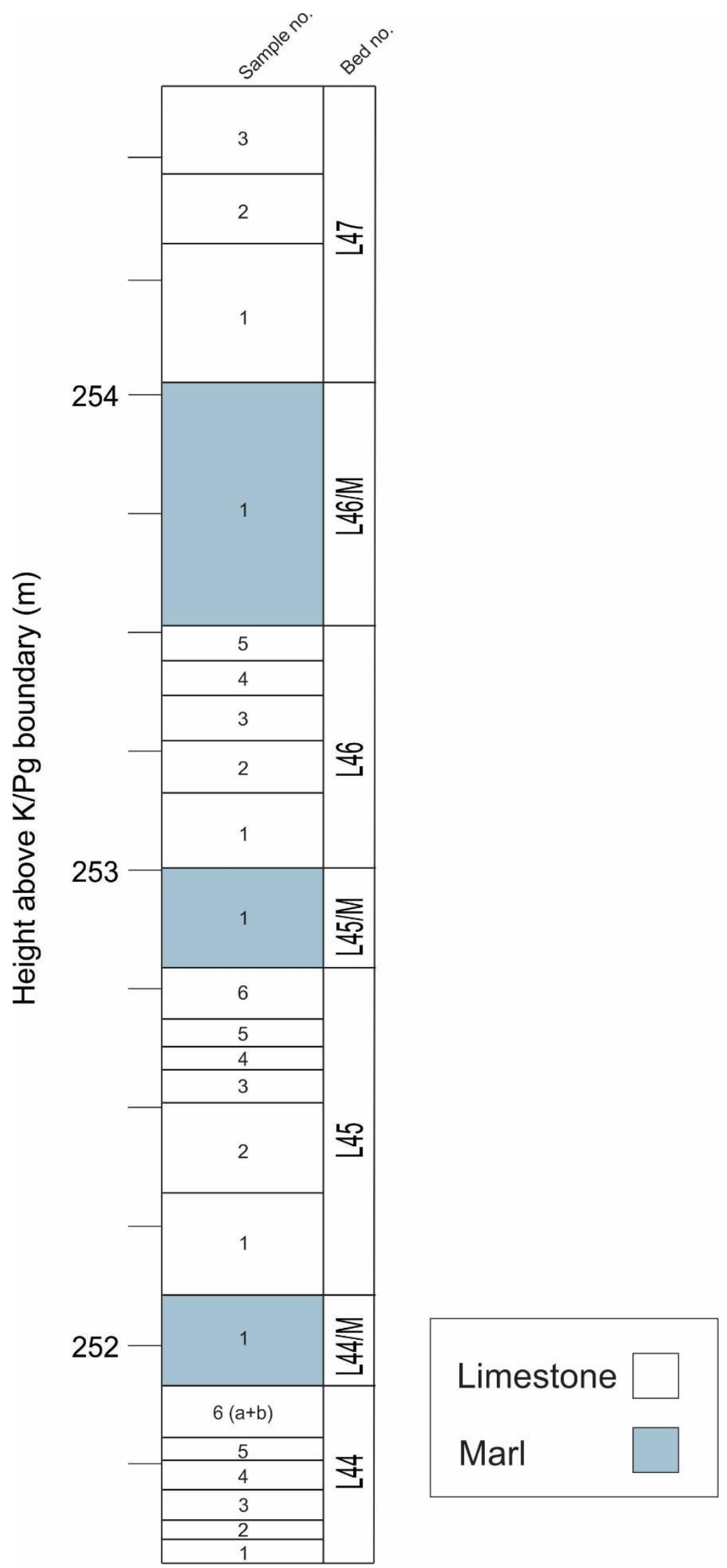

Figure 3.4: Set B samples relative to stratigraphy. 


\subsection{Palynological Sample Preparation}

Preparation and processing of palynological samples were completed in the Palynology Laboratory at GNS Science, Lower Hutt, New Zealand, with the assistance of Roger Tremain. Palynological procedure was followed as per Penafiel Bermudez \& Tremain (2013). Samples were initially dried and crushed to $<3 \mathrm{~mm}$ chips. As previously processed limestone samples from Mead Stream using the standard 30-50 g of sample yielded few palynomorphs a relatively large amount of sample (100-120 g, or the greatest possible amount where <100 g of sample was available) was processed. Single Lycopodium tablets (batch no. 1031) containing 20,848 spores ( $s= \pm 1546$ ) were added to each sample prior to further processing, in order to enable calculation of grain per gram abundances. Samples were subsequently treated in $10 \%$ hydrochloric acid to remove carbonate minerals, followed by a $50 \%$ hydrofluoric acid treatment to remove silicate minerals. Samples were then subjected to a second $10 \%$ hydrochloric acid treatment to remove any soluble fluorides, followed by several water washes to remove any remaining acid. Residual heavy minerals were separated from the organic fraction of the remaining sample by heavy liquid float in sodium polytungstate (specific gravity of 2). Organic fractions were retained and placed in an ultrasound bath for 30-60 seconds to disaggregate fine material and then filtered through a $6 \mu \mathrm{m}$ mesh. The $>6$ $\mu \mathrm{m}$ organic fraction was retained. Samples yielding low amounts of organic matter were not filtered. A second $6 \mu \mathrm{m}$ mesh filtration was carried out for samples with excess fine material where required. Finally, the remaining material was mounted on glass slides in a medium consisting of glycerol jelly mixed with an added drop of phenol red indicator. All processed samples yielded $\geq 2$ slides (one exception being L4/1, which returned one slide). Some remaining residues from samples were selected-based on their appearance in wet mountat the discretion of Mr. Tremain to be subjected to oxidation in nitric acid for one minute, followed by ammonia solution for a further minute, in order to remove extraneous organic debris before being mounted on supplementary slides. Processed samples are listed in appendix (B).

\subsection{Palynological Analyses}

51 samples-35 from Set $A$ and 16 from Set B-were scanned and counted in order to determine marine palynomorph assemblage abundances. A further 29 Lower Marl samples from the GNS Science palynology collections were scanned for marine palynomorph 
occurrences. A full list of encountered taxa can be found in appendix (C). Accompanying plates can be found in appendix (D). All taxonomic occurrences by sample are presented in appendix (E).

A Leica DM6 B microscope fitted with 10x, 20x, 40x, 63x, and 100x objective lenses was used to examine slides. A Leica DMC2900 camera was used for photomicrograph capture. Images were annotated with scale bars using the Leica Application Suite V.47 camera software package. Automatic brightness, white balance, and exposure settings were used, with some images subjected to further cropping and/or rotation. All slides from each sample were scanned using the $20 x$ and $40 x$ objectives prior to counting to determine the sample's complete marine palynomorph assemblage. All counts were undertaken using the $40 \mathrm{x}$ objective by counting across a left-to-right traverse of the slide, then upon completion of a traverse the stage was returned to the initial view and moved by a full field-of-view (FOV) diameter from top-to-bottom. This process was repeated until the target count was reached-a target count of 200 palynomorphs per sample was achieved where possible. Total Lycopodium spores found during the 200 marine palynomorph count were recorded as a separate count. Specimens were counted if more than a quarter of the grain was identifiable. Taxa were predominantly identified by comparison to images from relevant literatureincluding published papers, theses, and bulletins-in combination with personal communication with experts. Specimens lacking definitive taxonomic identifications were assigned to genus level where possible, or otherwise assigned to informal "types". Grains identifiable as marine palynomorphs without possibility of further description were counted as "indeterminate". 
Absolute marine palynomorph grain per gram abundances were calculated for all counted samples following the equation by Benninghoff (1962):

$$
c=\frac{d_{c} \times L_{t} \times t}{L_{c} \times w}
$$

Where:

c concentration, no. palynomorph grains/g dried sample

$d_{c} \quad$ number of counted palynomorphs

Lt number of Lycopodium spores/tablet

$t \quad$ number of tablets per sample

$L_{c} \quad$ number of counted Lycopodium spores

$W \quad$ weight of dried sediment $(\mathrm{g})$

Abundance data are presented in tables of both relative, and absolute grain per gram abundances per sample are in appendix (E).

\subsection{Palynofacies Analyses}

The selected 51 samples from Set A and Set B examined for palynological analyses were also counted for palynofacies analysis, as well as four limestone samples from the GNS Science collections. Palynofacies counts were completed following the methodology outlined in Clowes et al. (2016). All counts were completed using the 40x objective. Eyepiece crosshairs were oriented north-south. All organic particles that were $>15 \mu \mathrm{m}$ in at least one dimension and situated under the ten semi-major crosshairs were counted. After this count the stage was moved one half FOV diameter along the $x$-axis. At the end of each traverse the stage was moved a full FOV diameter along the $y$-axis and a new traverse begun. This was repeated until 300 observations were recorded per sample. This study categorises particulate organic matter using a scheme modified from Clowes et al. (2016). These categories are grouped into Amorphous Organic Matter (AOM), terrestrially derived phytoclasts and sporomorphs, and marine derived forams, acritarchs, dinocysts and other marine algae (FADO). The scheme used for this study is further explained in Table 3.1. Palynofacies count data can be found in appendix (F). 


\subsection{Stable Isotope Geochemistry}

Bulk stable carbon isotope $\left(\delta^{13} \mathrm{C}\right)$ measurements of the 75 samples comprising Set $A$ and Set $B$ were completed at the GNS Science Stable Isotope Laboratory, Lower Hutt. Samples were crushed to a fine powder onsite using a tungsten carbide ring and puck mill. Powdered samples were analysed using a GVI IsoPrime Carbonate Preparation System at a reaction temperature of $25^{\circ} \mathrm{C}$ for 24 hours then run by dual inlet on the IsoPrime mass spectrometer, as per Slotnick et al. (2015). Bulk carbonate $\delta^{13} \mathrm{C}$ values from high-resolution samples are reported in appendix (B). All results are reported in conventional delta notation with respect to Vienna PeeDee Belemnite and are normalized to internal standards (GNS Marble) with reported values of $2.04 \%$ for $\delta^{13} \mathrm{C}$. The external precision for these measurements is better than $0.1 \%$. 
Table 3.1: Palynofacies classification scheme.

\begin{tabular}{|c|c|c|}
\hline Group & Category & Description \\
\hline AOM & Amorphous Organic Matter (AOM) & $\begin{array}{l}\text { Heterogenic, structureless aggregates of organic matter with diffuse edges. AOM is produced primarily through bacterial degradation of marine organic } \\
\text { matter. It is most prevalent in low energy, anoxic marine environments and is considered autochthonous (Tyson, 1995). }\end{array}$ \\
\hline \multirow[t]{7}{*}{$\begin{array}{l}\text { Phytoclasts + } \\
\text { Sporomorphs }\end{array}$} & Spores \& Pollen (Sporomorphs) & $\begin{array}{l}\text { Includes all fossil pollen grains and spores. As terrestrial palynomorphs are rare in samples from the Lower Marl they provide little paleoenvironmental } \\
\text { information and are combined in a single group. }\end{array}$ \\
\hline & Fungal Remains & $\begin{array}{l}\text { Includes all fungal remains including spores, fruiting bodies, and hyphae. Hyphae can often appear in large tangled masses. Fungal remains are usually of } \\
\text { terrestrial origin and are grouped as such, however marine species do exist (Tyson, 1995). }\end{array}$ \\
\hline & Cells \& Cell Membranes & $\begin{array}{l}\text { Thin, sheet like structures, mostly leaf cuticles. Some retain cell structure. Can appear heavily folded or crumpled. This group is highly bouyant thus can be } \\
\text { dispersed great distances (Boulter and Riddick, 1986). }\end{array}$ \\
\hline & Brown Structured Phytoclasts & $\begin{array}{l}\text { Brown, translucent clasts of plant matter (wood or parenchyma) displaying some level of internal structure. This structure can include parallel linear } \\
\text { thickenings or xylem structures. }\end{array}$ \\
\hline & Brown Unstructured Phytoclasts & Brown, translucent clasts of poorly preserved plant matter displaying no clear internal structure. \\
\hline & $\begin{array}{l}\text { Opaque Phytoclasts (Lath-shaped \& } \\
\text { Equi-dimensional) }\end{array}$ & $\begin{array}{l}\text { Phytoclasts for which } \geq 90 \% \text { of the particle exhibits no translucency under } 500 x \text { magnification. This group represents plant matter oxidised pre-, syn-, or } \\
\text { post-depositionally. Opaque phytoclasts were counted as two groups based on shape: lath-shaped (straight, sub-parallel edges with one dimension two or } \\
\text { more times longer than the orthogonal measurement), and equi-dimensional. Lath-shaped clasts tend towards greater transport distances than equi- } \\
\text { dimensional ones due to the respective hydrodynamic properties of each shape (Tyson, 1995). }\end{array}$ \\
\hline & Resins \& Humic Gels & Vitreous, glossy, translucent particles. They are internally homogenous and coherent, and can form rounded bead-like to relatively angular shards. \\
\hline \multirow[t]{5}{*}{$\begin{array}{l}\text { Forams, } \\
\text { Acritarchs, } \\
\text { Dinocysts, } \\
\text { Other marine } \\
\text { algae (FADO) }\end{array}$} & Foraminferal test linings & Organic wall linings of foram tests. These are very rare in the Lower Marl samples. \\
\hline & Acritarchs \& Other marine algae & $\begin{array}{l}\text { Includes the Prasinophyte algae group, which have a steady presence in Lower Marl samples. No acritarchs were encountered in this study. Members of } \\
\text { this category are believed to originate in shallow water, near shore settings but may be transported great distances due to their diminutive, planktonic } \\
\text { nature (Tyson, 1995). }\end{array}$ \\
\hline & Dinocysts & $\begin{array}{l}\text { Dinocyst transport is variable due to the wide variety of morphologies they can exhibit, although overall they are believed to behave hydrodynamically } \\
\text { like silt particles (Tyson 1995). }\end{array}$ \\
\hline & Zoomorphs & Usually large, disarticulated zoomorph fragments. \\
\hline & Unknown & This category is for probable marine palynomorphs that are too degraded to be specifically placed. \\
\hline
\end{tabular}




\section{Chapter 4: Results}

Palynological assemblages recovered from the Lower Marl at Mead Stream consist of dinocysts, prasinophyte algae, and sparse sporomorphs, with dinocysts forming over $50 \%$ of all assemblages. Dinocysts occur in all Set A and Set B samples. Preservation of dinocysts and prasinophyte algae is varied between samples, ranging from very poor (specimen identification not possible) to good (most key features of the cyst discernable). Quantitative palynological analysis was possible for all samples except L1/M/1.

\subsection{Lower Marl Dinocyst Biostratigraphy}

The Lower Marl section can be biostratigraphically correlated to other early Eocene sections around New Zealand using combination of the early Eocene New Zealand dinocyst zonation schemes proposed by Wilson (1988), and Crouch (2001). The four zones recognised within the Lower Marl at Mead Stream are NZE2-NZE4, and Charlesdowniea coleothrypta. The NZE2 zone is further subdivided into "a" and " $b$ " subzones. NZE3 and NZE4 are equivalent to the Dracodinium waipwaense Zone and the Wilsonidium ornatum Zone of Wilson (1988) respectively. Dinocyst zones recognised at Mead Stream are based on the lowest stratigraphic occurrences (LOs) of key taxa outlined by Wilson (1988) and Crouch (2001) (Fig. 4.1).

\section{NZE2 (late Waipawan; $\leq 186.620-206.300 \mathrm{~m}$ )}

The lowermost samples from this study are associated with the NZE2 zone based primarily on the presence of Samlandia delicata (LO $204.715 \mathrm{~m}$; LO/1). The LO of Impagidinium cassiculum - which defines the base of the NZE2b subzone-is at $206.226 \mathrm{~m}$ (L2/6); however, based on previous correlations with calcareous nannoplankton zones it is likely the base of NZE2 $b$ is situated below the examined interval at Mead Stream. The stratigraphically lowest samples from this study coincide with calcareous nannoplankton zone NP11, whereas the base of NZE2b is situated within calcareous nannoplankton zone NP10 (Crouch, 2001, Pers. Comms. E. Crouch). The NP9/NP10 boundary at Mead Stream is estimated to occur between 160-170 m (Dallanave et al., 2015) which would imply the NZE2b base is stratigraphically nearby. The Lower Limestone-Lower Marl transition occurs during NZE2 (Fig. 4.1).

\section{NZE3 (latest Waipawan; 206.300-279.300 m)}

The base of this zone at Mead Stream, which is defined by the LO of Dracodinium waipawaense, is recognised at $206.300 \mathrm{~m}$ (L2/8). Other characteristic taxa for 
this zone that have been identified in this study include other Dracodinium species, Homotryblium tasmaniense (LO 204.715 m; LO/1), Rottnestia borrussica (LO as per $H$. tasmaniense), and Schematophora obscura (LO $229.150 \mathrm{~m}$; L25d/M). A single species of Wetzeliella (LO $251.743 \mathrm{~m}$; L44/4) also appears within this zone. All samples from Set A and Set $B$ are situated within this zone.

\section{NZE4 (Mangaorapan; 279.300-317.700 m)}

The base of this zone is defined by the first occurrence of Wilsonidium ornatum. The LO of Wilsonidium ornatum at Mead Stream is at $279.300 \mathrm{~m}$ (L100/M). Other characteristic NZE4 taxa indentified include Hystrichokolpoma bullatum (LO 251.743 m; L44/4), Hystrichokolpoma spinosum (LO $250.150 \mathrm{~m}$; L42c/M), and Mebranophoridium perforatum (LO $260.100 \mathrm{~m}$; L52/M). Each of these first occur below the LO of Wilsonidium ornatum. A significant sample gap from $262.960-279.300 \mathrm{~m}$ should be noted as a limit on biostratigraphic resolution.

\section{Charlesdowniea coleothrypta (Mangaorapan; 317.700 m-?)}

This zone was originally published as the Kisselovia coleothrypta zone by Wilson (1988) and is defined by the LO of the eponymous species. As Kisselovia coleothrypta has subsequently been reclassified as Charlesdowniea coleothrypta (Lentin and Vozzhennikova, 1989) this zone is referred to as such herein. The LO of Charlesdowniea coleothrypta at Mead Stream is in the uppermost Lower Marl at $317.700 \mathrm{~m}$ (L114/M) and the zone extends into the Upper Limestone. 


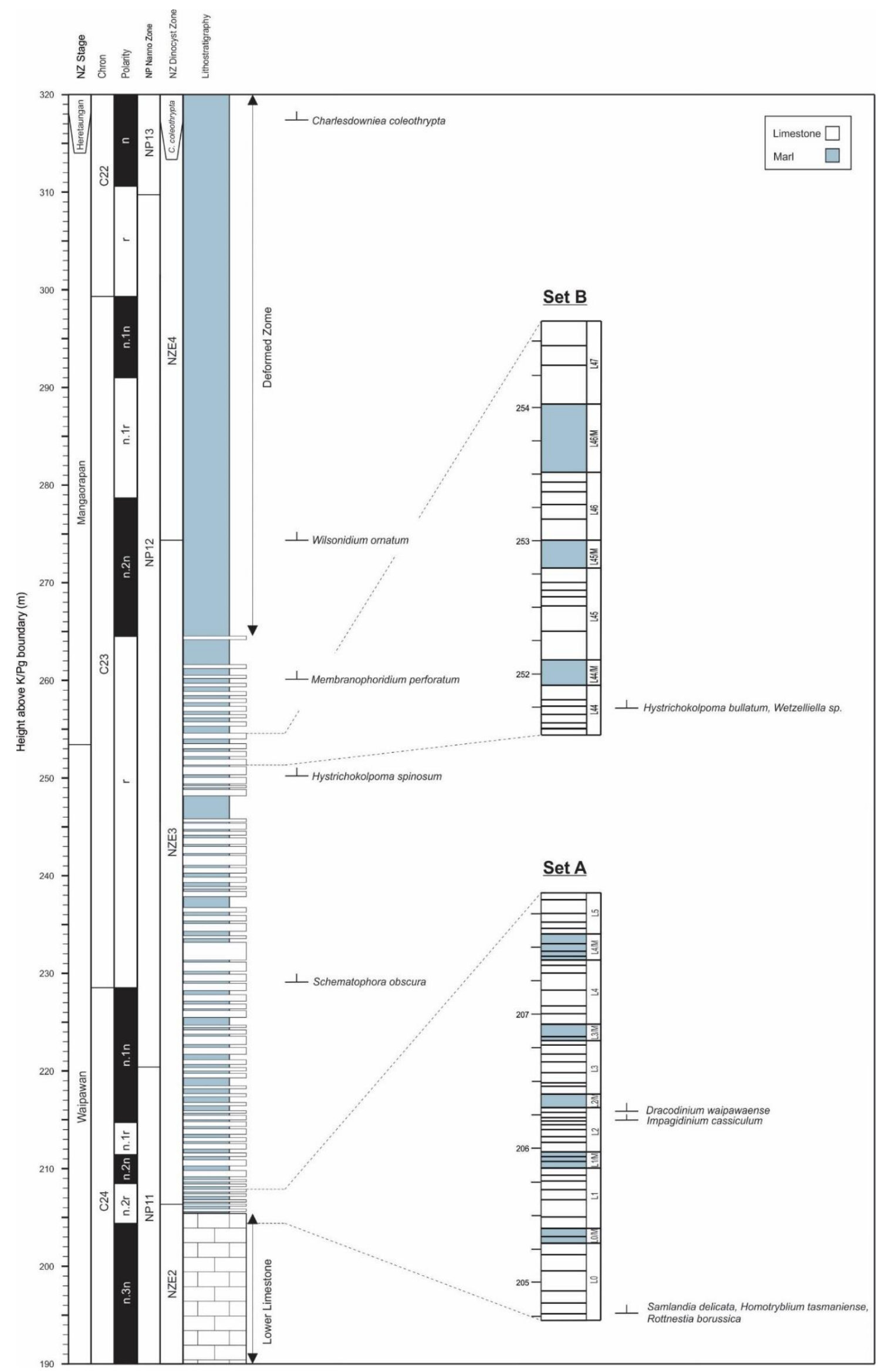

Figure 4.1: New Zealand dinocyst zonation, and LOs of key dinocyst taxa from the Lower Marl, Mead Stream. Magnetostratigraphy and NP Nanno zones from Dallanave et al. (2015). 


\subsection{Marine Palynomorph Abundances}

\subsubsection{Overall Trends \& Features}

Assemblages for both Set A and Set B are typically dominated by Spiniferites spp. with consistent background presence (5-20\%) of Operculodinium spp., Pyxidinopsis spp., and prasinophyte algae comprising both Cymatiosphaera sp. and Pterospermella sp. (Fig. 4.2-4.5). Both sets are dominated by G-cyst type dinocysts, which comprise $\geq 97 \%$ of relative abundances for all samples. Species of the Impagidinium genus, which are indicators for deeper oceanic environments (Brinkhuis, 1994), are low in abundance across both intervals $(<10 \%$, excepting $L 0 / M / 2$ and $L 3 / 1$ from Set $A)$.

\subsubsection{Set A Relative and Absolute Abundances}

Absolute grain per gram abundances for Set $A$ are presented in Figure 4.2. Relative abundances are presented in Figure 4.3. No apparent relationship between lithotype and either absolute or relative marine palynomorph abundances was observed. Two significant peaks of Homotryblium tasmaniense comprising $>80 \%$ of the assemblage, as well as significantly elevated total $\mathrm{g}^{-1}$ abundances occur between L2/3-L2/8 (206.137-206.300 m), and L3/5-L3/M/1 (206.699-206.829 m). Both of these peaks occur during the J CIE and the first of these peaks is coincident with the onset of the J CIE. Absolute abundances through L4-immediately above the uppermost Homotryblium tasmaniense peak-are extremely low $\left(<25 \mathrm{~g}^{-1}\right)$.

\subsubsection{Set B Relative and Absolute Abundances}

Absolute $\mathrm{g}^{-1}$ abundances for Set B are presented in Figure 4.4. Relative abundances are presented in Figure 4.5. Dinocyst g-1 abundances are significantly greater in marls (>350 g $\mathrm{g}^{-1}$, $\left.\overline{\mathrm{x}}_{\text {marl }}=769 \mathrm{~g}^{-1}\right)$ than in limestones $\left(<260 \mathrm{~g}^{-1}, \overline{\mathrm{x}}_{\text {limestone }}=99 \mathrm{~g}^{-1}\right)$. Relative abundances of prasinophyte algae display a saw tooth-like trend with greatest abundances occurring at the base of each limestone unit and decreasing into the overlying marl unit. Prasinophyte $\mathrm{g}^{-1}$ abundances are steady across the interval $\left(10-35 \mathrm{~g}^{-1}\right)$, hence this saw tooth trend is most likely a reflection of a relative lack of dinocysts in limestone samples. 


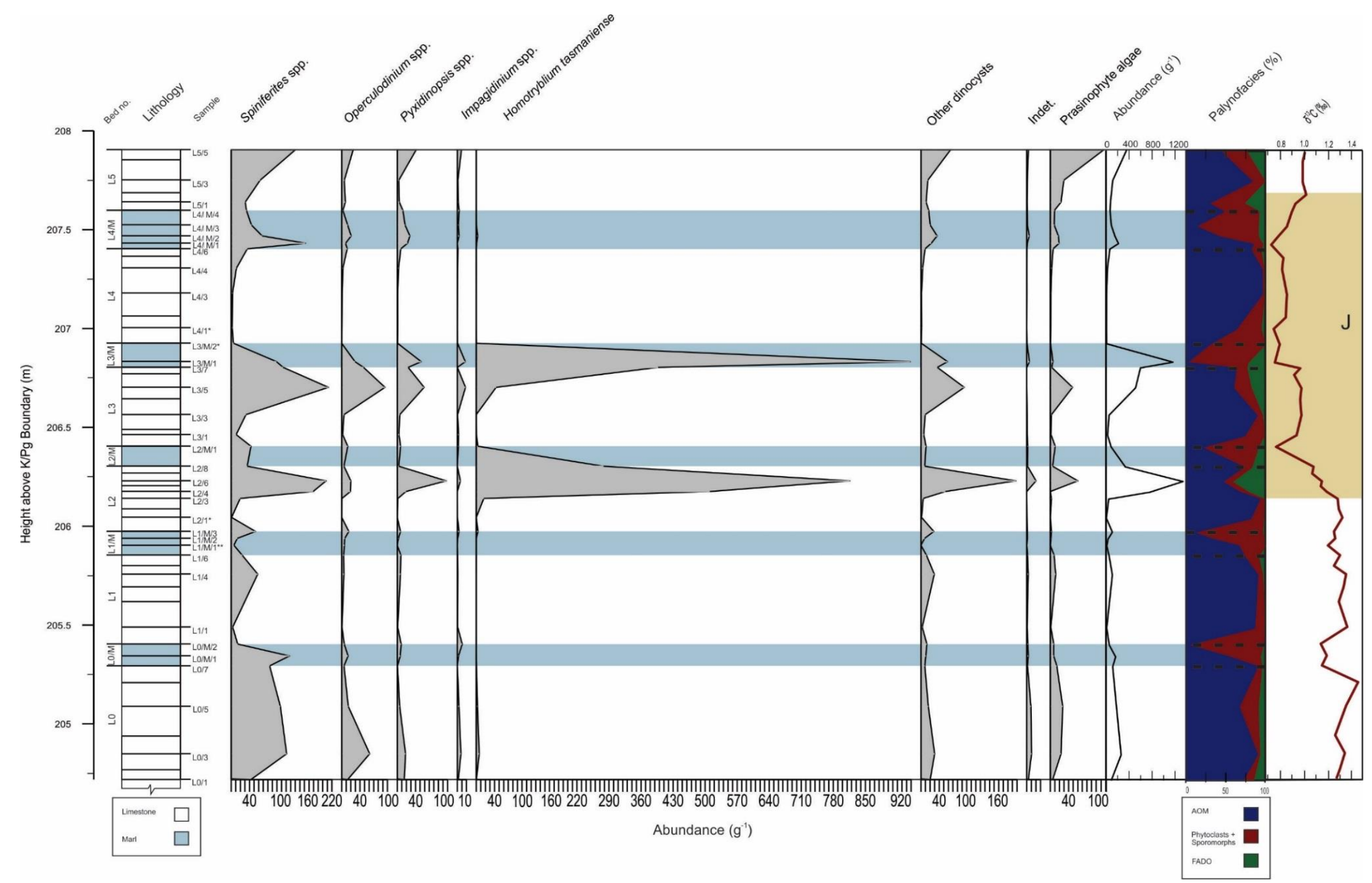

Figure 4.2: Absolute $\mathrm{g}^{-1}$ abundances for set A samples, grouped by most commonly occurring palynomorph types. ${ }^{*}$ denotes samples that returned a count of <200, $* *$ denotes samples excluded from analysis due to low count. Palynofacies abundances and carbon isotope stratigraphy are shown on the right hand side. 


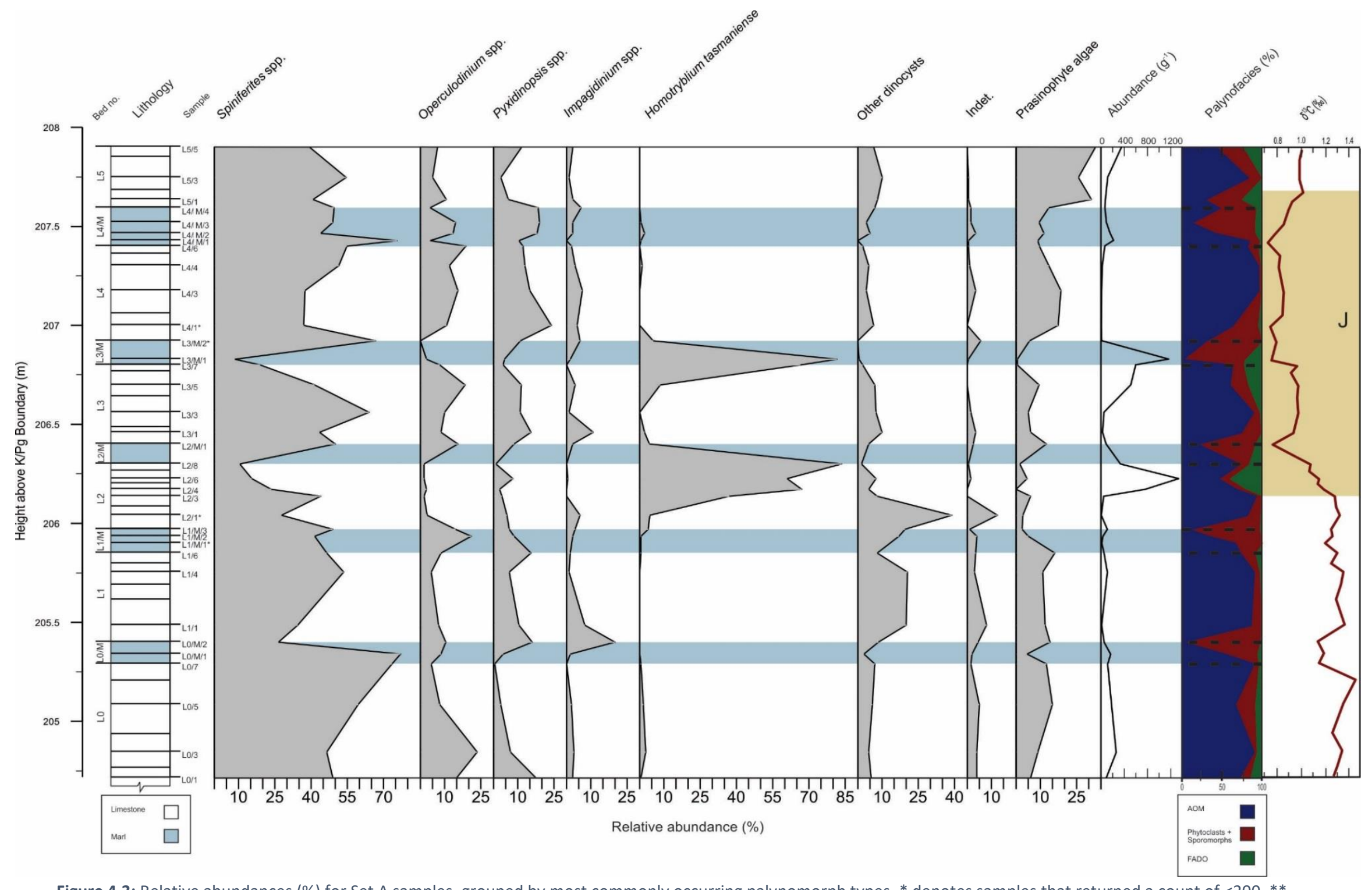

Figure 4.3: Relative abundances (\%) for Set A samples, grouped by most commonly occurring palynomorph types. * denotes samples that returned a count of <200, ** denotes samples excluded from analysis due to low count. Palynofacies abundances and carbon isotope stratigraphy are shown on the right hand side. 


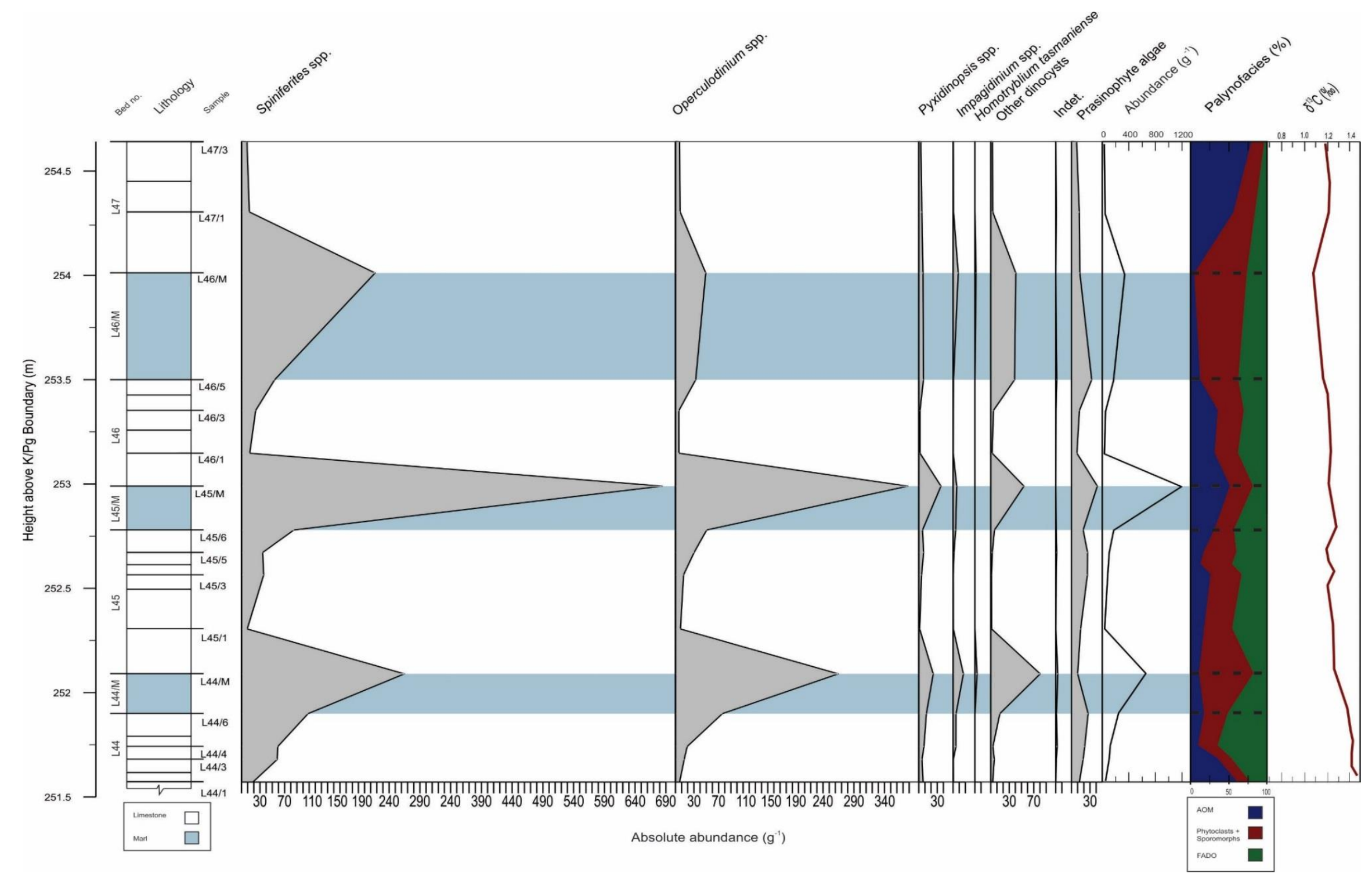

Figure 4.4: Absolute $\mathrm{g}^{-1}$ abundances for Set B samples, grouped by most commonly occurring palynomorph types. Palynofacies abundances and carbon isotope stratigraphy are shown on the right hand side. 


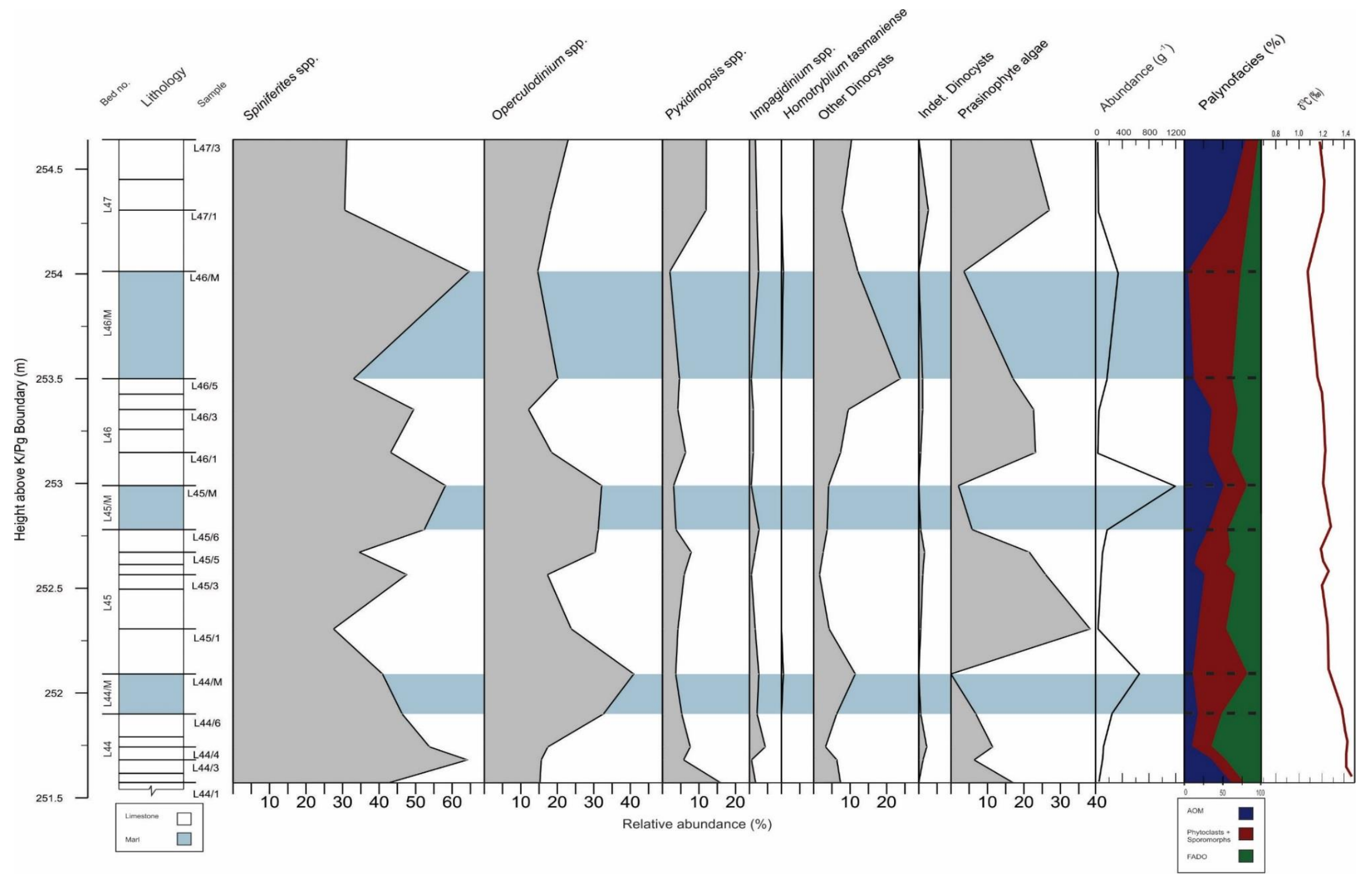

Figure 4.5: Relative abundances (\%) for Set B samples, grouped by most commonly occurring palynomorph types. Palynofacies abundances and carbon isotope stratigraphy are shown on the right hand side. 


\subsection{Palynofacies}

\subsubsection{Overall Trends \& Features}

Figures 4.6 \& 4.7 show palynofacies data plotted by categories for Set A and Set B respectively. Limestone samples are dominated by marine-derived organic matter from the AOM and FADO groups. Marl samples, however, are comparatively more abundant in terrigenous matter in most cases. Fungal remains are consistently more abundant in marls, with the presence in limestones ranging from extremely low $(<5 \%)$ to absent. The majority of opaque phytoclasts from all samples are equi-dimensional in shape.

\subsubsection{Set A Palynofacies}

Results from Set A show a strong relationship between palynofacies and lithology. AOM content is consistently greater in all limestone samples (>66\%), whereas the majority of marl samples comprise $<50 \%$ AOM; conversely, terrigenous fractions (Phytoclasts+Sporomorphs) are $<20 \%$ in limestone samples (excepting L5/1 \& L5/5). Terrigenous content in all marl samples (except L4/M/1) is $>33 \%$, with all relevant categories increasing in abundance in these beds. Increases in the abundance of the FADO group between L2/3-L2/8 (206.137$206.300 \mathrm{~m})$, and L3/5-L3/M/1 (206.699-206.829 $\mathrm{m}$ ) are reflective of the two peaks of Homotryblium tasmaniense.

\subsubsection{Set B Palynofacies}

The relationship between palynofacies and lithology is less apparent across Set B; however, this could be a data-related issue due to a lack of marl samples being collected ( 3 samples). Limestone samples comprise $>50 \%$ marine-derived organic matter. Unlike limestone samples from set $A$, the majority marine component for Set B is the FADO group (with the exception of L44/1, L47/1, \& L47/3), as opposed to AOM. In limestones, the majority constituent of the FADO group is generally marine (prasinophyte) algae, whereas in uppermost samples from limestone beds, and marls dinocysts are more prevalent. Total Phytoclasts+Sporomorphs percentages are generally greater for Set $B\left(\bar{X}_{\text {Set }} B=34.7 \%\right)$ than for Set $A\left(\bar{x}_{\text {Set }} A=28.5 \%\right)$. Most phytoclast and sporomorph constituent groups are relatively steady across the interval, with the exception of fungal remains which are greatest in marl samples. 


\subsubsection{Facies Types}

Palynofacies data from both sample sets are plotted by organic matter group on ternary diagrams after Roncaglia and Kuijpers (2006) (Fig. 4.8). Figure 4.8a presents an overall view of all data, while Figure $4.8 \mathrm{~b}$ shows individual plots of limestone and marl data for each set. Four additional limestone samples from recognised carbon isotope excursions (CIEs) at Mead Stream-K, L-1, BS-CIE-10, BS-CIE-16 (Slotnick et al., 2015)-are also included in Figure 4.8a. Based on approximate groupings of data points, samples have been assigned to one of three facies types:

\section{Type I}

Facies Type I is characterised by relatively high phytoclast and sporomorph content. This is interpreted as representing increased influx of terrigenous organic matter (i.e. enhanced continental runoff) into the marine setting.

\section{Type II}

This type is characterised by relatively high AOM content. The major terrestrial component of this facies is opaque phytoclasts. Type II is interpreted to represent a dysoxic-anoxic marine environment, as high AOM abundances are associated with these conditions (Tyson, 1995).

\section{Type III}

Type III facies is characterised by a somewhat greater proportion of FADO group organic matter and relatively minor AOM and phytoclast and sporomorph components. This type is interpreted as being representative of a relatively well-oxygenated offshore environment based on higher relative abundances of planktonic marine organisms and low AOM content. 


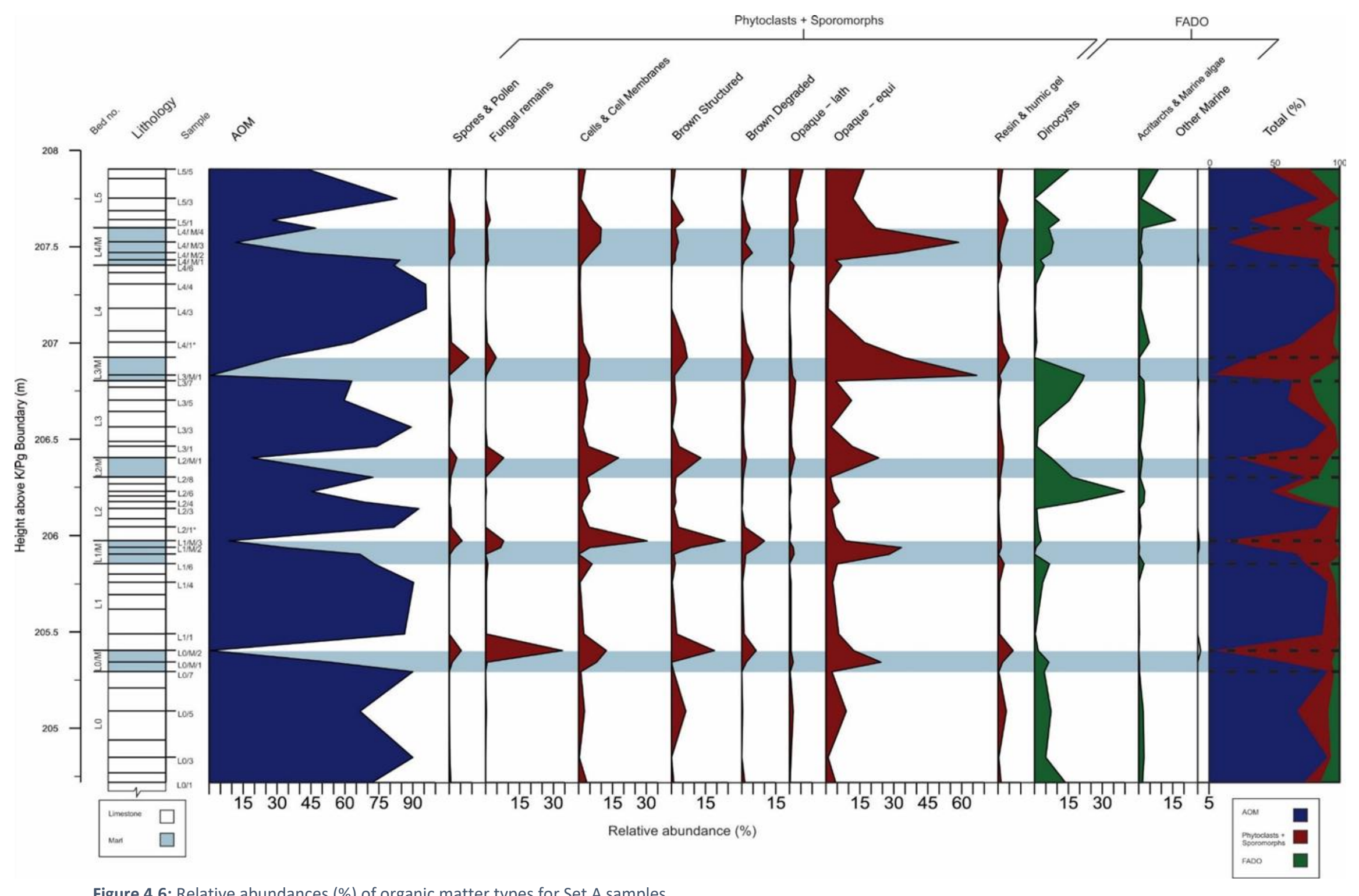

Figure 4.6: Relative abundances (\%) of organic matter types for Set A samples 


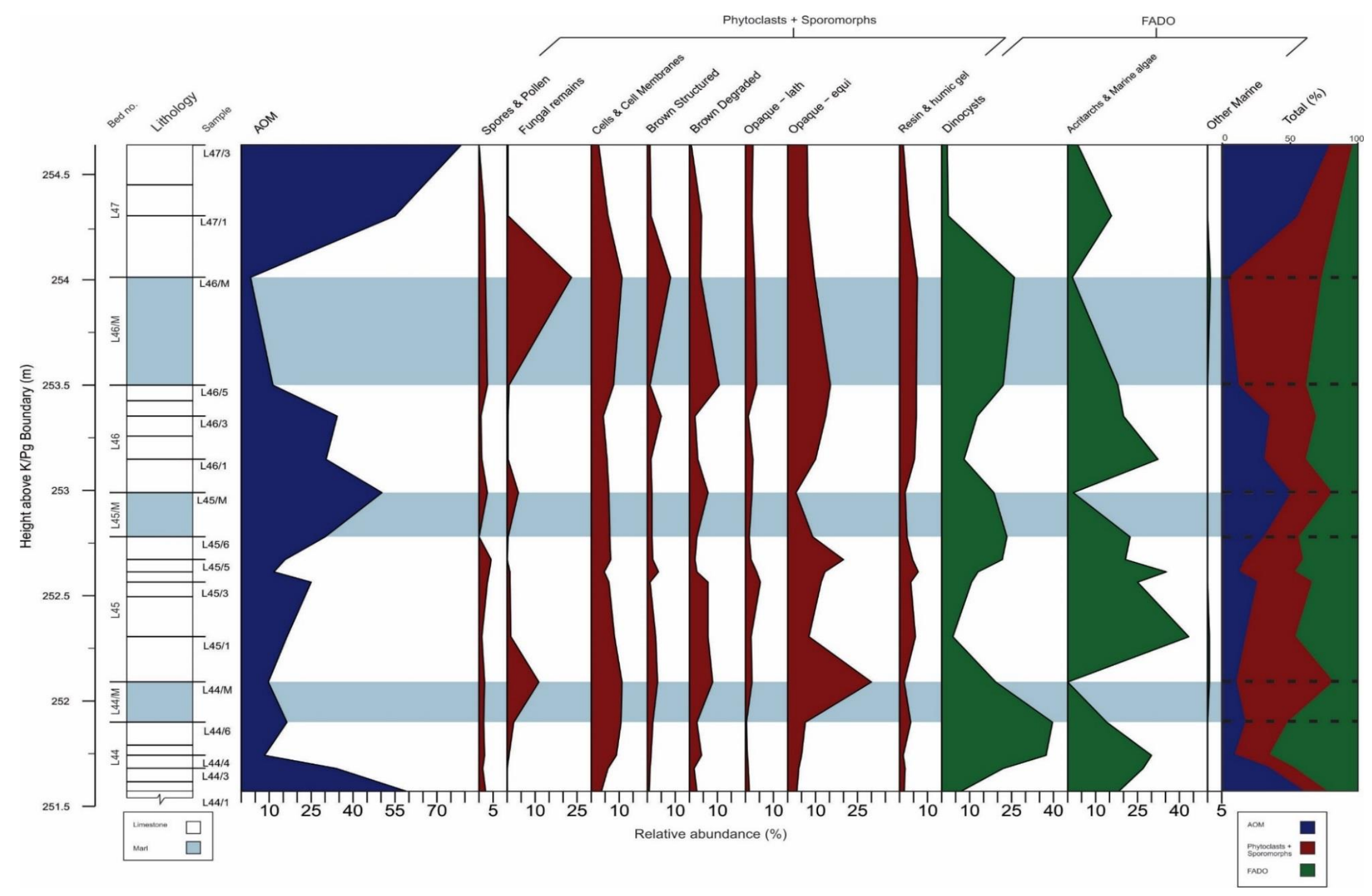

Figure 4.7: Relative abundances (\%) of organic matter types for Set B samples. 

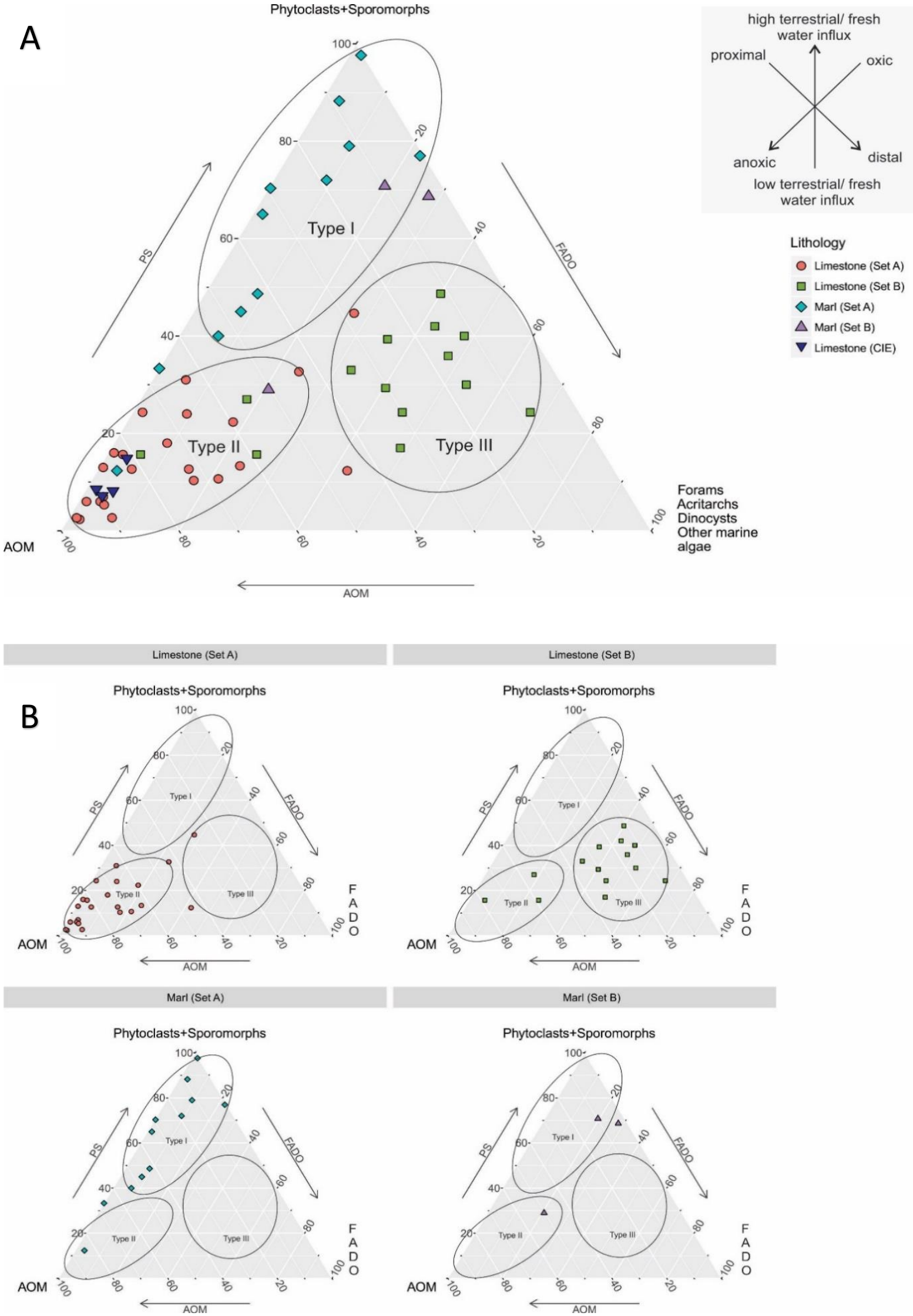

Figure 4.8: A, total distribution of palynofacies data, after Roncaglia \& Kuijpers (2006), B, palynofacies data presented by sample set and lithotype. 


\subsection{Carbon Isotope Stratigraphy}

Bulk carbonate $\delta^{13} \mathrm{C}$ values from this study are plotted against those from Slotnick et al. (2015) in Figure 4.9. Results from this study show a good overall agreement with the published record. Although $\delta^{13} \mathrm{C}$ values for Set $\mathrm{B}$ limestones from this study are slightly higher than those from the previously reported data, they still plot within the $0.1 \%$ margin of error. Greater resolution of sampling from this study shows the initial $-0.3 \%$ drop in $\delta^{13} \mathrm{C}$ identified as the onset of the J CIE by Slotnick et al. (2012) occurs at $206.201 \mathrm{~m}$-stratigraphically lower than the previously reported height of $206.5 \mathrm{~m}$. The top of this event remains unchanged at the subsequent increase to $1.0 \%$, thus the J CIE spans 206.201-207.83 m at Mead Stream. ${ }^{13} \mathrm{C}$ values for marls may be underestimated, as marls comprise greater amounts of terrigenous content which may contain isotopically-light, organic carbon (Slotnick et al., 2012). Any presence of this isotopically-light, organic carbon would effectively lower bulk carbonate values. 


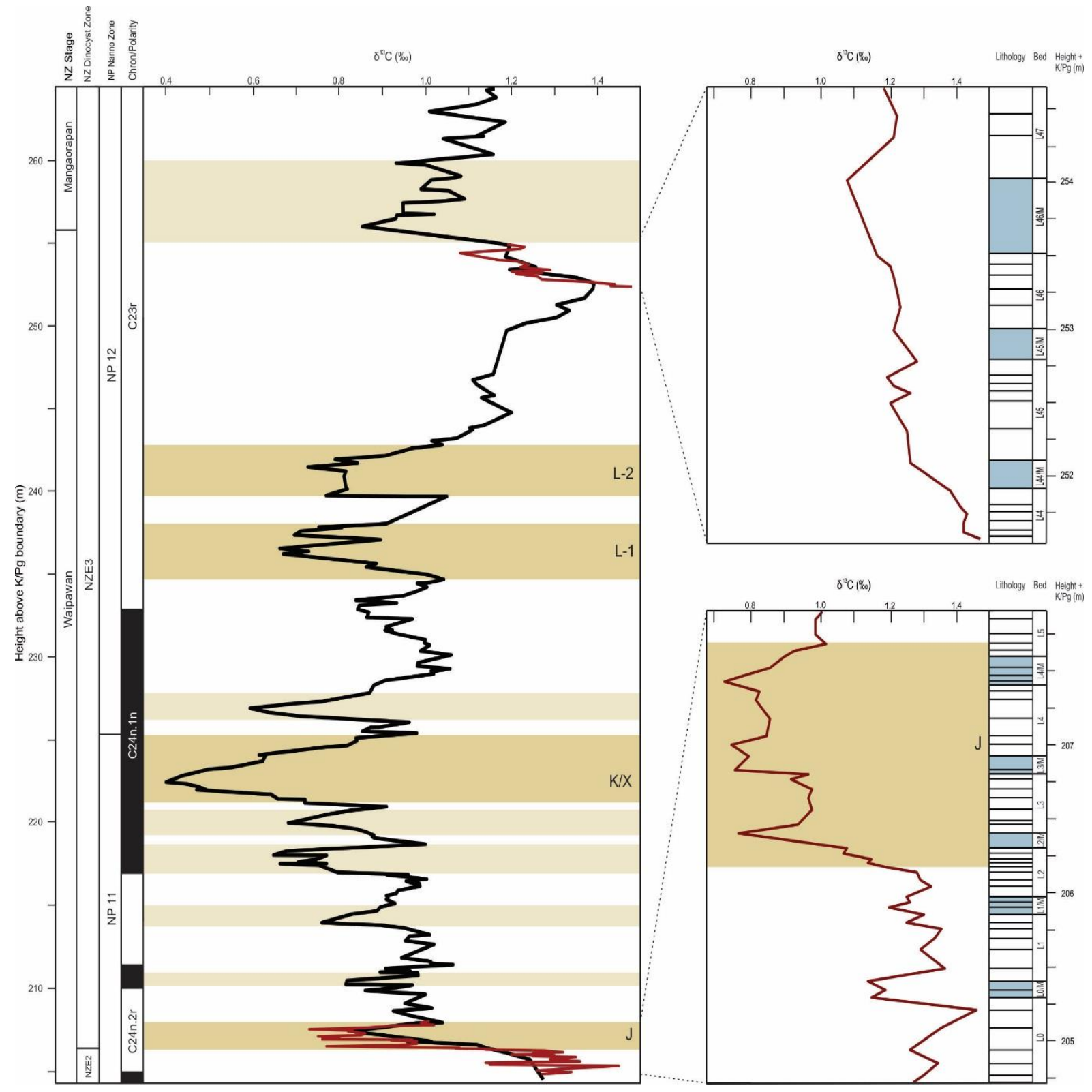

Figure 4.9: Bulk carbonate $\delta^{13} \mathrm{C}$ carbon isotope stratigraphy for the undeformed section of the Lower Marl, Mead Stream. Black curve shows data from Slotnick et al. (2012), red curves and insets show data from this study (Set A and Set B). Tan intervals represent recognised CIEs, dark tan intervals represent globally correlated CIEs and are labelled accordingly after Slotnick et al. (2012). 


\section{Chapter 5: Interpretation and Discussion}

\subsection{Biostratigraphy}

Early Eocene New Zealand dinocyst zones across the Lower Marl at Mead Stream are well established in this study for the first time-improving the poorly-resolved zonation outlined by Strong et al. (1995). Zone boundaries within the studied interval include NZE2/NZE3, NZE3/NZE4, and NZE4/Charlesdowniea coleothrypta. Each of these zones are defined by the relevant primary dinocyst bioevents-i.e. the LOs of Dracodinium waipawaense, Wilsonidium ornatum, and Charlesdowniea coleothrypta respectively (Wilson 1988, Crouch 2001). The defined range of each zone as presented, with the exception of the Charlesdowniea coleothrypta zone, is further supported by the presence of several characteristic taxa (see section 4.1; Fig. 4.1).

Overall, the dinocyst zones recorded here compare well with equivalent regional sections at Tawanui, southern Hawkes Bay, and mid-Waipara River, Canterbury Basin (Fig. 1.3, Fig 2.3); however, LOs of the primary taxa mentioned above appear to occur later at Mead Stream than at mid-Waipara River (Crouch, 2001, Dallanave et al., 2016). The LO of Dracodinium waipawaense at mid-Waipara River is estimated to occur within Chron C24r whereas it occurs within Chron C24n.2n at Mead Stream. The LO of Wilsonidium ornatum at mid-Waipara River (estimated to fall within Chron C23r) is slightly earlier than at Mead Stream (Chron C23n.2n); however, this disparity may be a sampling artefact due to relatively poor palynological sampling resolution through the deformed zone of the Lower Marl at Mead Stream. The gap in sampling $(262.960-279.300 \mathrm{~m})$ immediately below the reported LO of Wilsonidium ornatum (279.300 m) at Mead Stream partially spans Chron C23r; therefore, if that interval contains a lower occurrence of Wilsonidium ornatum then the timing of the LOs at both locations could be comparable. It should also be noted magnetostratgraphic ages for the LOs of Dracodinium waipawaense and Wilsonidium ornatum at mid-Waipara River are estimates, as they occur outside the magnetostratigraphically controlled part of the section. The slightly later LO of Charlesdowniea coleothrypta at Mead Stream (Chron C22n), than at mid-Waipara River (Chron C22r), could similarly be the result of a sampling gap from 310.470$317.700 \mathrm{~m}$; thus, this event may be somewhat synchronous at Mead Stream and mid-Waipara River, as the LO of Charlesdowniea coleothrypta at both sites is situated close the C22r/C22n boundary. 
The LO of Homotryblium tasmaniense recorded in L0/1 (204.715 m) within Chron C24n.2r, and predating the J CIE ( 53.42-53.35 Ma; Dallanave et al., 2015), likely represents the earliest reported occurrence of this species in the southwest Pacific region, predating several other noted occurrences. In the New Zealand region Wilson (1988) reports a lower Mangaorapan age for the LO for Homotryblium tasmaniense at the Waipawa section, Hawkes Bay, and Dallanave et al. (2016) report an age of $\sim 52.6 \mathrm{Ma}$ (calcareous nannofossil zone NP11) from the mid-Waipara River. Carpenter et al. (2012) report a LO of Homotryblium tasmaniense from the wider southwest Pacific region (Australo-Antarctic gulf; paleolatitude $65^{\circ} \mathrm{S}$ ) with an estimated maximum age of $\sim 53 \mathrm{Ma}$. Bijl et al. (2013) report LOs of Homotryblium tasmaniense at $\sim 50 \mathrm{Ma}$ from the East Tasman Plateau, as well as the Wilkes Land Margin, Antarctica.

\subsection{Paleoenvironment \& Paleoclimate}

\subsubsection{Palynofacies Types}

Samples included in palynofacies analysis have been grouped into one of three facies types, as discussed above (section 4.3.5; Fig. 4.8). Environmental interpretations of palynofacies types are as follows:

\section{Type I}

Samples associated with the Type I facies are relatively rich in terrigenous organic matter and represent periods of increased terrestrial runoff onto the upper slope at Mead Stream. Based on this greater terrigenous component, type I samples reflect warmer periods, during which the hydrological cycle intensifies, and subsequently enhances continental runoff (Hollis et al., 2005b, Slotnick et al., 2012). Greater abundances of fungal remains in Type I samples could be a supporting indicator of climatic warming, and greater precipitation, as fungi are known to thrive in response to such changes (Talley et al., 2002, Beggs, 2004). All samples associated with Type I are marls (Fig. 4.8b).

\section{Type $/ 1$}

Type II palynofacies compositions contain relatively high AOM content. This may indicate both calm hydrolographic conditions and reduced terrigenous influx, dysoxic-anoxic conditions, or a combination of these (Tyson, 1995). If this facies type is indicative of calm conditions it may represent baseline conditions due to a minimal influence from allochthonous palynodebris. Alternatively, it is possible high abundances of AOM could reflect an expansion of an 
intermediate oxygen minimum zone in response to ocean warming, and $\mathrm{CO}_{2}$ injection (Matear et al., 2000). Set A limestones are typically associated with Type II, as well as each of the four "CIE" limestone samples (Fig. 4.8).

\section{Type III}

Facies Type III is relatively more abundant in marine plankton. As these plankton have probably been transported from the shelf to the slope (see section 5.2.3), this type likely represents a higher-energy, marine environment than that associated with Type II (Roncaglia \& Kuijpers 2006). Limestone samples from Set B predominantly associate with Type III facies (Fig. 4.8b).

\subsubsection{Paleoclimate inferences from Organic Matter}

Palynofacies data from Set A samples show a strong relationship between lithotype and palynofacies, whereby lithological change from limestone to marl is consistently reflected in palynofacies as a change from Type II to Type I. This shows that although no clear climatic signal is present in marine palynomorph assemblages, the organic fractions of Lower Marl sediments do appear to record changes in temperature and precipitation through variation in terrestrial runoff (see section 2.5). Rhythmic sequences of limestone and marl beds deposited during greenhouse climates found at Dorset, England, and the Cretaceous Western Interior Seaway, USA, have been shown to exhibit similar patterns of terrestrial-rich (marl) and marine-rich (limestone) palynofacies (Eldrett et al., 2015, Waterhouse, 1999). In both these examples spectral analyses suggest the terrestrial-marine palynofacies cycles are driven by orbital forcing-specifically the precessional cycle in shallower (shelf-upper slope) environments. The precessional cycle is thought to modulate seasonality and precipitation in greenhouse climates (Gallimore et al., 1986, Meyers et al., 2001). A precessional cause for the Type I-Type II cycles in Set A samples cannot be statistically assessed in this study due to an insufficient number of measured cycles; however, the similarities between climatic effects associated with precession and those associated with marl deposition, as well as precedent from other comparable examples would suggest such an explanation is plausible and cannot be over-looked.

The slight increase in overall terrigenous content in Set B samples $\left(\bar{X}_{\text {terrigenousB }}=34.7 \%\right)$ from Set A samples ( $\bar{x}_{\text {terrigenousA }}=30.6 \%$ ), as well as the switch from typically Type II limestones in Set A to typically Type III limestones in Set B may be reflective of long-term EECO related warming. 
As the continental margin at the time was passive, relief of the continental hinterland was probably relatively low and likely remained somewhat consistent between deposition of Set A and Set B sediments (King, 1999). This would suggest the overall increase in allochthonous organic matter in Set B samples was the result of increasing surface runoff caused by greater long-term precipitation, and not increasing sediment supply from enhanced continental relief (Rafalska-Bloch and Cunningham, 1986). Such an increase in precipitation would be an expected hydrological response to background temperatures approaching peak EECO values around the early Mangaorapan (Slotnick et al., 2012, Hollis et al., 2009).

\subsubsection{Marine Palynomorph Assemblages}

Lower Marl dinocyst assemblages from Mead Stream are typical of an outer-neritic environment ( 100-200 m water depth) based on the G-cyst distribution model proposed by Brinkhuis (1994) (Fig. 5.1). This model describes the distribution of G-cyst dinocysts along a distal-proximal transect spanning the continental shelf. This is also consistent with the nearshore-offshore dinocyst trend presumed by Crouch and Brinkhuis (2005). Common inner-outer neritic taxa in Lower Marl samples include specimens from the Spiniferites, Operculodinium, Cordosphaeridium, Homotryblium, and Hystrichosphaeridium genera, with Spiniferites and Operculodinium being the most abundant taxa in the section overall. Prasinophyte algae-which are consistently present through the section-are similarly known to prefer nearshore-inner neritic environments (Powell et al., 1992, Leliaert et al., 2012). As the Amuri Limestone at Mead Stream is understood to have been deposited in deeper conditions on the paleo-slope (Crampton et al., 2003), the persistent neritic assemblages probably indicate steady shelf-slope transport of marine palynomorphs. Micritic limestone and marl beds in the Lower Marl lack any sedimentological structures indicative of highenergy sediment gravity flow onto the slope; therefore, neritic marine palynomorphs were probably transported to the slope in a low-energy hydrodynamic regime. Steady background presences $\left(\sim 15-30 \mathrm{~g}^{-1}\right)$ of prasinophyte algae across Set A and Set B likewise imply low-energy transport from the shelf, as prasinophyte algae are known to prefer low-turbidity environments (Tyson, 1995).

High relative proportions ( $>30 \%$ ) of Spiniferites and Operculodinium have been associated with the margins of fluvial discharge plumes and warm SSTs (Zonneveld et al. 2009). In lower Marl samples from Mead Stream these taxa typically compose $>40 \%$ of assemblages. This 
association may be applicable in this case, as it has been shown marl horizons are thicker at sites closer to the ancient shoreline (such as Branch Stream), than at Mead Stream (Slotnick et al., 2015). The more proximal sites would probably be situated closer to the body of any fluvial discharge plumes, and would therefore experience greater terrigenous sedimentation resulting in thicker expression of marl horizons.

Palynofacies analysis also supports the concept of a low-energy depositional setting. Type II AOM-rich samples may represent periods of relatively calm hydrographic conditions-AOM is autochthonous marine matter, and is dominant in carbonate systems when conditions are relatively calm and influx of other organic matter is low (Tyson, 1995, Gedl, 2014). Furthermore, all samples contain greater abundances of equi-dimensional opaque phytoclasts than lath-shaped opaque phytoclasts (Figs. $4.6 \& 4.7$ ). Equi-dimensional opaque phytoclasts tend towards lesser transport distances than their lath-shaped counterparts due to their less streamlined morphology (Tyson, 1995).

Members of the genus Impagidinium (and possibly Pyxidinopsis) are typically considered to indicate deeper, oceanic (slope-bathyal) conditions (Brinkhuis, 1994, Crouch and Brinkhuis, 2005). Therefore, background presence (5-20\%) of these taxa in many samples may represent an element of in-situ deposition, as opposed to mass transport.

Limited information regarding paleo-SST trends can be derived from Lower Marl dinocyst assemblages. Two "cool water" endemic transantarctic taxa after Bijl et al. (2011)Membranophoridium perforatum, and Deflandrea convexa-are identified in Lower Marl samples; however, occurrences are very sparse. "Warm water" dinocysts such as Apectodinium (Crouch, 2001, Crouch and Brinkhuis, 2005) are also generally absent or sparse, with very minor abundances $(<3 \%)$ of the Wetzeliella genus occurring through 10 of the 15 Set B samples. The notable exception is the significant abundance of Homotryblium tasmaniense in the dual peaks in Set A (206.137-206.300 m, 206.699-206.829 m; Figs. 4.2 \& 4.3) - occurring within the J $\mathrm{CIE}$, therefore likely reflective of transient hyperthermal warming. No clear overall temperature signal for the Lower Marl at Mead Stream can be determined from abundances of either cool water transantarctic taxa, or warm water taxa due to general scarcity of both groups. Furthermore, no clear signal of temperature change between lithotypes can be determined, as the abovementioned taxa occur in both limestone and marl samples. 
Relative P-cyst abundances can be used as indicators of surface productivity in neritic settings, whereby higher proportions of P-cysts correspond to higher surface productivity (e.g. Crouch, 2001). G-cysts comprise $\geq 97 \%$ of all Lower Marl assemblages, which could mean local surface productivity at the time was especially low; alternatively, if the lack of P-cysts in the Lower Marl is due to some unidentified factor (e.g. oxidising conditions), P/G cyst ratios simply may not be a suitable indicator of surface productivity in this instance.

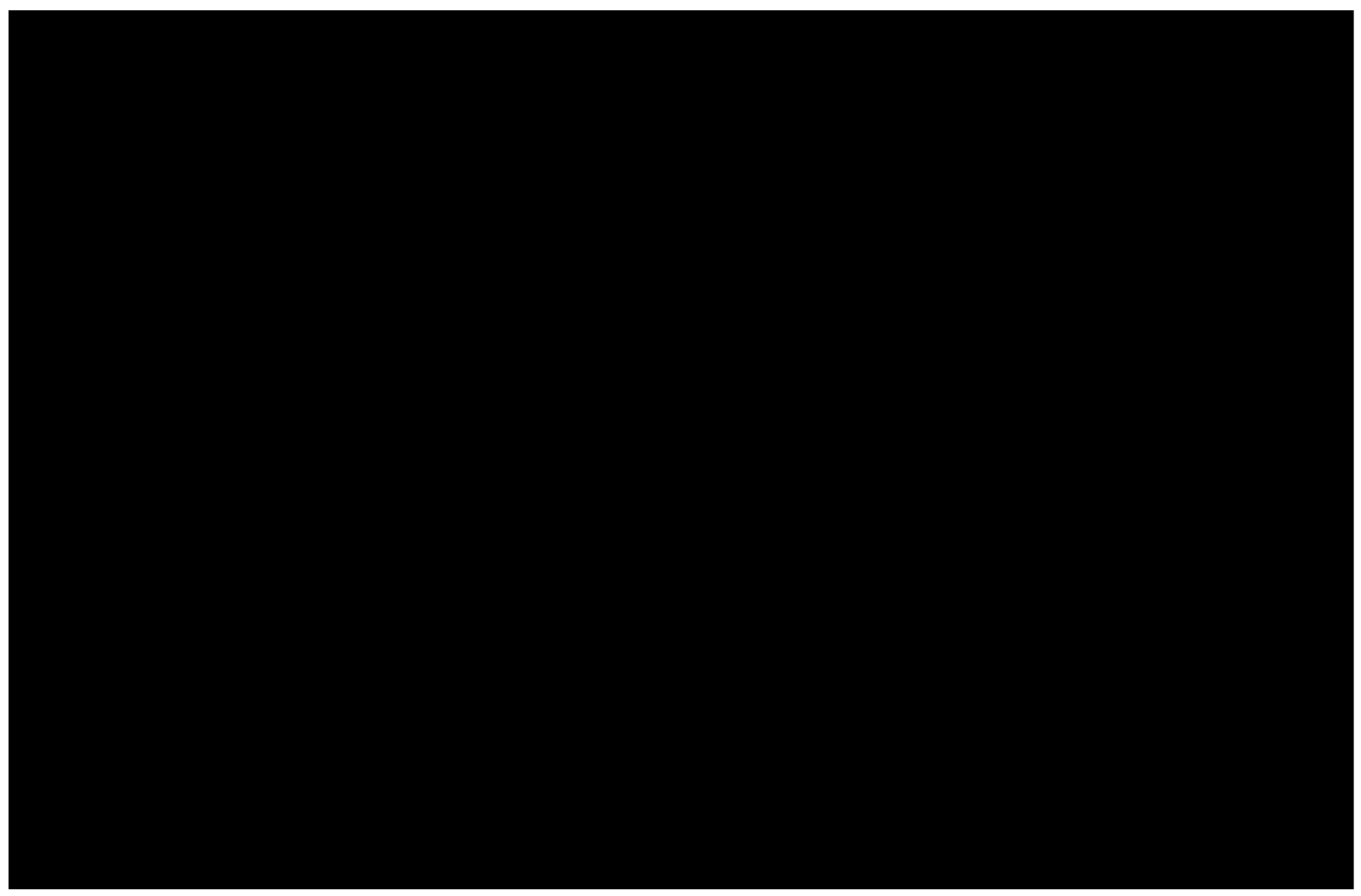

Figure 5.1: Schematic model for the distribution of $\mathrm{G}$ cyst dinocysts along a proximal-distal transect. Image from Sluijs et al. (2005), after Brinkhuis (1994). 


\subsection{Biotic Response During the J CIE}

The redefined base for the J CIE at Mead Stream (206.201 m; L2/5) determined in this study, coincides with the occurrence of the earlier of the two Homotryblium tasmaniense peaks (206.137-206.300 m; L2/3-L2/8). These peaks in Homotryblium tasmaniense likely reflect a biotic response to the onset of warming, and are indicators of paleoenvironmental conditions during the hyperthermal.

The Homotryblium genus is known to occur in warm water (subtropical), restricted marine environments, and is usually associated with high or low salinity (de Verteuil and Norris, 1996, Brinkhuis, 1994). Homotryblium cyst-producing dinoflagellates appear to have gone extinct in the late Miocene; however, the modern dinoflagellate Pyrodinium bahamense is believed to be related as it produces cysts (Polysphaeridium zoharyi) that are morphologically comparable to Homotryblium (de Verteuil and Norris, 1996, Dybkjær, 2004). Pyrodinium bahamense is a red tide species known to form blooms in semi-restricted embayments-potentially not unlike the shallowest margins of the Marlborough paleoembayment-when warmer and wetter conditions prevail (Dybkjær, 2004). The significantly high abundances of Homotryblium tasmaniense ( $>70 \%$ of the total assemblage) at the onset of the J CIE at Mead Stream most likely reflect prevailing environmental conditions like those described above. Freshwater runoff onto the continental margin in the paleo-Marlborough region would have increased, as the seasonal precipitation intensified due to the warming climate (Slotnick et al., 2012). Fresher, lower-salinity surface layers (due to freshwater influx) and higher subtropical-like SSTs, combined with increased oxygen dissolution due to greater influx of terrigenous matter, would in turn cause stratification of the water column (Meyers, 2006). Red tide-type dinoflagellates (such as Pyrodinium bahamense) are known to bloom in more stratified conditions (Katz et al., 2004).

An interval of extremely low absolute abundances $\left(<25 \mathrm{~g}^{-1}\right)$ occurs through $L 4$ (207.000$207.400 \mathrm{~m}$ ) at Mead Stream, immediately above the later of the two Homotryblium tasmaniense peaks (206.699-206.829 m; L3/5-L3/M/1). This period of extremely low abundances may be reflective of the transient warming during the hyperthermal. Frieling et al. (2017) note that during the PETM in the tropics, dinocyst $\mathrm{g}^{-1}$ abundances significantly increase by $1-2$ orders of magnitude (from $10^{3} \mathrm{~g}^{-1}$ to $10^{4}-10^{5} \mathrm{~g}^{-1}$ ) in response to the initial onset of warming, before abruptly dropping to $<10^{2} \mathrm{~g}^{-1}$ through the 
middle section of the hyperthermal, and recovering to pre-onset abundances during the latest stages. They attribute the initial dinocyst bloom during the onset of the PETM to the initial increase in SSTs, and the subsequent dearth of dinocysts to heat stress, whereby peak PETM SSTs became uninhabitable for most dinoflagellate taxa present. The findings of Frieling et al. (2017) are not strictly comparable to the J CIE at Mead Stream, as they report findings from a low-latitude site, and peak PETM temperatures were $3-6^{\circ} \mathrm{C}$ warmer than peak J CIE temperatures (Lauretano et al., 2015); however, the initial bloom and subsequent dearth of dinocysts across the J CIE at Mead Stream displays a pattern not unlike that noted by Frieling et al. (2017). This could mean the interval of extremely low dinocyst abundances through L4 represents a period where subtropical-tropical SSTs, unsuitable for mid-latitude dinocysts typical of Lower Marl assemblages, prevail at Mead Stream. In the context of the wider southwest Pacific region, this would suggest during the hyperthermal event subtropical-tropical SSTs expanded to the mid-high latitudes-at least as far as $50^{\circ} \mathrm{S}$. 


\section{Chapter 6: Conclusions}

This study set out to undertake the first in-depth palynological investigation of the Lower Marl at Mead Stream, New Zealand. Marine palynomorph assemblages, as well as palynofacies analysis were used to make paleoenvironmental and paleoclimatic interpretations. Key findings of this study can be summarised as follows:

1. Early Eocene New Zealand dinocyst zones after Wilson (1988) and Crouch (2001) have been well established across the Lower Marl at Mead Stream for the first time in this study. All zones from NZE2-NZE4 and the Charlesdowniea coleothrypta zone are recognised, and defined by primary bioevents. The earliest known occurrence of Homotryblium tasmaniense ( $53.42-53.35 \mathrm{Ma}$ ) is recorded in this study.

2. Marine palynomorph assemblages from the Lower Marl at Mead Stream are characteristic of outer-neritic environments. Palynomorphs were likely transported from the shelf and deposited on the slope in a low-energy regime. This may have occurred along the margin of a terrestrial discharge plume. A general scarcity of noted warm or cool water taxa precludes any interpretation of SST trends based on palynomorph assemblages. A lack of P-cyst dinocysts may be indicative of extremely low surface productivity, however, it is more likely this proxy for sea surface productivity is not suitable for Mead Stream during the early Eocene.

3. Cycles in palynofacies types between marine-dominant limestones to terrestrialdominant marls are present across Set A. These cycles display many similarities with comparable sections where limestone-marl alternations have been determined to have been the result of modulation of seasonal precipitation by the precessional cycle. A precessional cause for terrestrial-marine palynofacies alternations, and therefore limestone-marl deposition, at Mead Stream cannot be determined from the data set from this study. 
4. An increase in total allochthonous organic matter from Set A to Set B is likely reflective of long-term warming of global temperatures culminating during the early Mangaorapan Stage, and the associated long-term intensification of seasonal precipitation.

5. The base for the J event at Mead Stream was redefined at $206.201 \mathrm{~m}$. The onset of this hyperthermal coincides with two significant peaks in abundance of Homotryblium tasmaniense. An interval of extremely low absolute abundances immediately follows the second peak of Homotryblium tasmaniense. This dearth in marine palynomorphs may indicate a period of subtropical SST expansion to the midhigh latitudes in the southwest Pacific region, wherein dinoflagellates may have significantly reduced in numbers due to heat stress and uninhabitable SSTs. 


\section{References}

BEGGS, P. J. 2004. Impacts of climate change on aeroallergens: past and future. Clinical \& Experimental Allergy, 34, 1507-1513.

BENNINGHOFF, W.S. 1962. Calculation of pollen and spores density in sediments by addition of exotic pollen in known quantities. Pollen et Spores. Vol. IV, No. 2. P. 332-333

BIJL, P. K., PROSS, J., WARNAAR, J., STICKLEY, C. E., HUBER, M., GUERSTEIN, R., HOUBEN, A. J., SLUIJS, A., VISSCHER, H. \& BRINKHUIS, H. 2011. Environmental forcings of Paleogene Southern Ocean dinoflagellate biogeography. Paleoceanography, 26 PA1202, 1-12.

BIJL, P. K., SCHOUTEN, S., SLUIJS, A., REICHART, G.-J., ZACHOS, J. C. \& BRINKHUIS, H. 2009. Early Palaeogene temperature evolution of the southwest Pacific Ocean. Nature, 461, 776-779.

BIJL, P. K., SLUIJS, A. \& BRINKHUIS, H. 2013. A magneto-and chemostratigraphically calibrated dinoflagellate cyst zonation of the early Palaeogene South Pacific Ocean. EarthScience Reviews, 124, 1-31.

BINDER, B. J. \& ANDERSON, D. M. 1986. Green light-mediated photomorphogenesis in a dinoflagellate resting cyst. Nature, 322, 659-661.

BOULTER, M. C. \& RIDDICK, A. 1986. Classification and analysis of palynodebris from the Palaeocene sediments of the Forties Field. Sedimentology, 33, 871-886.

BRINKHUIS, H. 1994. Late Eocene to Early Oligocene dinoflagellate cysts from the Priabonian type-area (Northeast Italy): biostratigraphy and paleoenvironmental interpretation. Palaeogeography, Palaeoclimatology, Palaeoecology, 107, 121-163.

CARPENTER, R. J., JORDAN, G. J., MACPHAIL, M. K. \& HILL, R. S. 2012. Near-tropical Early Eocene terrestrial temperatures at the Australo-Antarctic margin, western Tasmania. Geology, 40, 267-270.

CLOWES, C.D., PREBBLE, J., CROUCH, E.M., RONCAGLIA, L. 2016. Development and multioperator calibration of a standardised palynofacies analysis technique. GNS Science Report 2016/19. 47 p.

COLLINS, M., KNUTTI, R., ARBLASTER, J., DUFRESNE, J.-L., FICHEFET, T., FRIEDLINGSTEIN, P., GAO, X., GUTOWSKI, W., JOHNS, T. \& KRINNER, G. 2013. Long-term climate change: projections, commitments and irreversibility. Climate Change 2013: The Physical Science Basis. IPCC Working Group I Contribution to AR5.

CONTRERAS, L., PROSS, J., BIJL, P. K., KOUTSODENDRIS, A., RAINE, J. I., VAN DE SCHOOTBRUGGE, B. \& BRINKHUIS, H. 2013. Early to middle Eocene vegetation dynamics at the Wilkes Land Margin (Antarctica). Review of Palaeobotany and Palynology, 197, 119-142.

CRAMER, B. S., WRIGHT, J. D., KENT, D. V. \& AUBRY, M. P. 2003. Orbital climate forcing of $\delta 13 \mathrm{C}$ excursions in the late Paleocene-early Eocene (chrons C24n-C25n). Paleoceanography, 18 (4), 1097.

CRAMPTON, J., LAIRD, M., NICOL, A., TOWNSEND, D. \& VAN DISSEN, R. 2003. Palinspastic reconstructions of southeastern Marlborough, New Zealand, for mid-CretaceousEocene times. New Zealand Journal of Geology and Geophysics, 46, 153-175.

CROUCH, E. M. 2001. Environmental Change at the Time of the Paleocene-Eocene Biotic Turnover: Met Een Samenvatting in Het Nederlands, LPP Foundation, Utrecht University. 
CROUCH, E. M. \& BRINKHUIS, H. 2005. Environmental change across the Paleocene-Eocene transition from eastern New Zealand: a marine palynological approach. Marine Micropaleontology, 56, 138-160.

DALE, B. 1996. Dinoflagellate cyst ecology: modeling and geological applications. In JANSONIUS, J.; MCGREGOR, D.C. (eds.) Palynology: principles and applications. American Association of Stratigraphic Palynologists Foundation 1: 81-106.

DALE, B. 2001. The sedimentary record of dinoflagellate cysts: looking back into the future of phytoplankton blooms. 2001, 65, 16.

DALLANAVE, E., AGNINI, C., BACHTADSE, V., MUTTONI, G., CRAMPTON, J. S., STRONG, C. P., HINES, B. R., HOLLIS, C. J. \& SLOTNICK, B. S. 2015. Early to middle Eocene magnetobiochronology of the southwest Pacific Ocean and climate influence on sedimentation: Insights from the Mead Stream section, New Zealand. Geological Society of America Bulletin, 127, 643-660.

DALLANAVE, E., BACHTADSE, V., CROUCH, E. M., TAUXE, L., SHEPHERD, C. L., MORGANS, H. E., HOLLIS, C. J., HINES, B. R. \& SUGISAKI, S. 2016. Constraining early to middle Eocene climate evolution of the southwest Pacific and Southern Ocean. Earth and Planetary Science Letters, 433, 380-392.

DE VERTEUIL, L. \& NORRIS, G. 1996. Middle to upper Miocene Geonettia clineae, an opportunistic coastal embayment dinoflagellate of the Homotryblium Complex. Micropaleontology, 42(3), 263-284.

DECONTO, R. M., GALEOTTI, S., PAGANI, M., TRACY, D., SCHAEFER, K., ZHANG, T., POLLARD, D. \& BEERLING, D. J. 2012. Past extreme warming events linked to massive carbon release from thawing permafrost. Nature, 484, 87-91.

DICKENS, G. R. 2011. Down the rabbit hole: Toward appropriate discussion of methane release from gas hydrate systems during the Paleocene-Eocene thermal maximum and other past hyperthermal events. Climate of the Past, 7, 831-846.

DYBKJ/ER, K. 2004. Morphological and abundance variations in Homotryblium-cyst assemblages related to depositional environments; uppermost Oligocene-Lower Miocene, Jylland, Denmark. Palaeogeography, Palaeoclimatology, Palaeoecology, 206, 41-58.

ELDRETT, J. S., MA, C., BERGMAN, S. C., OZKAN, A., MINISINI, D., LUTZ, B., JACKETT, S.-J., MACAULAY, C. \& KELLY, A. E. 2015. Origin of limestone-marlstone cycles: astronomic forcing of organic-rich sedimentary rocks from the Cenomanian to early Coniacian of the Cretaceous Western Interior Seaway, USA. Earth and Planetary Science Letters, 423, 98-113.

EVITT, W. R. 1985. Sporopollenin dinoflagellate cysts: their morphology and interpretation. American Association of Stratigraphic Palynologists Foundation. 333 p.

FAGEL, N. 2007. Chapter four clay minerals, deep circulation and climate. Developments in marine geology, 1, 139-184.

FRIELING, J., GEBHARDT, H., HUBER, M., ADEKEYE, O. A., AKANDE, S. O., REICHART, G.-J., MIDDELBURG, J. J., SCHOUTEN, S. \& SLUIJS, A. 2017. Extreme warmth and heatstressed plankton in the tropics during the Paleocene-Eocene Thermal Maximum. Science advances, 3, e1600891.

GALEOTTI, S., KRISHNAN, S., PAGANI, M., LANCI, L., GAUDIO, A., ZACHOS, J. C., MONECHI, S., MORELLI, G. \& LOURENS, L. 2010. Orbital chronology of Early Eocene hyperthermals from the Contessa Road section, central Italy. Earth and Planetary Science Letters, 290, 192-200. 
GALLIMORE, R. G., OTTO-BLIESNER, B. L. \& KUTZBACH, J. E. 1986. The effects of improved parameterizations for orography, snowcover, surface fluxes and condensational processes on the climate of a low resolution GCM. Journal of the atmospheric sciences, 43, 1961-1983.

GEDL, P. 2014. Eocene dinoflagellate cysts from the Sołokija Graben (Roztocze, SE Poland). Geological Quarterly, 58, 707-728, doi: 10.7306/gq. 1167.

HELD, I. M. \& SODEN, B. J. 2006. Robust responses of the hydrological cycle to global warming. Journal of climate, 19, 5686-5699.

HINES, B. R. 2012. The Early Paleogene Succession at Tora, New Zealand; Stratigraphy and Paeloclimate: A Critical North Island Eocene Temperature Record and a Crucial Linkage Between the Depositional Settings of the Central and Southern East Coast Basin. MSc thesis, Victoria University of Wellington. $224 \mathrm{p}$.

HINES, B. R., HOLLIS, C. J., ATKINS, C. B., BAKER, J. A., MORGANS, H. E. \& STRONG, P. C. 2017. Reduction of oceanic temperature gradients in the early Eocene Southwest Pacific Ocean. Palaeogeography, Palaeoclimatology, Palaeoecology, 475, 41-54.

HOLLIS, C. J. 2006. Radiolarian faunal turnover through the Paleocene-Eocene transition, Mead Stream, New Zealand. Eclogae Geologicae Helvetiae, 99 (supplement 1), 79-99.

HOLLIS, C., FIELD, B., JONES, C., STRONG, C., WILSON, G. \& DICKENS, G. 2005 a.

Biostratigraphy and carbon isotope stratigraphy of uppermost Cretaceous-lower Cenozoic Muzzle Group in middle Clarence valley, New Zealand. Journal of the Royal Society of New Zealand, 35, 345-383.

HOLLIS, C. J., DICKENS, G. R., FIELD, B. D., JONES, C. M. \& STRONG, C. P. 2005b. The Paleocene-Eocene transition at Mead Stream, New Zealand: a southern Pacific record of early Cenozoic global change. Palaeogeography, Palaeoclimatology, Palaeoecology, 215, 313-343.

HOLLIS, C. J., HANDLEY, L., CROUCH, E. M., MORGANS, H. E., BAKER, J. A., CREECH, J., COLLINS, K. S., GIBBS, S. J., HUBER, M. \& SCHOUTEN, S. 2009. Tropical sea temperatures in the high-latitude South Pacific during the Eocene. Geology, 37, 99102.

HOLLIS, C. J., TAYLOR, K. W., HANDLEY, L., PANCOST, R. D., HUBER, M., CREECH, J. B., HINES, B. R., CROUCH, E. M., MORGANS, H. E. \& CRAMPTON, J. S. 2012. Early Paleogene temperature history of the Southwest Pacific Ocean: Reconciling proxies and models. Earth and Planetary Science Letters, 349, 53-66.

HUBER, M. \& SLOAN, L. C. 2001. Heat transport, deep waters, and thermal gradients: Coupled simulation of an Eocene greenhouse climate. Geophysical Research Letters, 28, 3481-3484.

HYLAND, E. G., SHELDON, N. D. \& COTTON, J. M. 2017. Constraining the early Eocene climatic optimum: A terrestrial interhemispheric comparison. Geological Society of America Bulletin, 129, 244-252.

INGLIS, G. N., COLLINSON, M. E., RIEGEL, W., WILDE, V., FARNSWORTH, A., LUNT, D. J., VALDES, P., ROBSON, B. E., SCOTT, A. C. \& LENZ, O. K. 2017. Mid-latitude continental temperatures through the early Eocene in western Europe. Earth and Planetary Science Letters, 460, 86-96.

KATZ, M. E., FINKEL, Z. V., GRZEBYK, D., KNOLL, A. H. \& FALKOWSKI, P. G. 2004. Evolutionary trajectories and biogeochemical impacts of marine eukaryotic phytoplankton. Annu. Rev. Ecol. Evol. Syst., 35, 523-556. 
KING, P. R. 1999. Cretaceous to Recent sedimentary patterns in New Zealand, Institute of Geological \& Nuclear Sciences.

LAURETANO, V., LITTLER, K., POLLING, M., ZACHOS, J. \& LOURENS, L. 2015. Frequency, magnitude and character of hyperthermal events at the onset of the Early Eocene Climatic Optimum. Climate of the Past, 11. 1313-1324.

LELIAERT, F., SMITH, D. R., MOREAU, H., HERRON, M. D., VERBRUGGEN, H., DELWICHE, C. F. \& DE CLERCK, O. 2012. Phylogeny and molecular evolution of the green algae. Critical Reviews in Plant Sciences, 31, 1-46.

LENTIN, J. \& VOZZHENNIKOVA, T. 1989. The fossil dinoflagellate cysts Kisselovia emend. and Charlesdowniea gen. nov. Review of Palaeobotany and Palynology, 58, 215-229.

LITTLER, K., RÖHL, U., WESTERHOLD, T. \& ZACHOS, J. C. 2014. A high-resolution benthic stable-isotope record for the South Atlantic: Implications for orbital-scale changes in Late Paleocene-Early Eocene climate and carbon cycling. Earth and Planetary Science Letters, 401, 18-30.

LUDWIG, W. \& PROBST, J.-L. 1998. River sediment discharge to the oceans; present-day controls and global budgets. American Journal of Science, 298, 265-295.

MACRAE, R. A., FENSOME, R. A. \& WILLIAMS, G. L. 1996. Fossil dinoflagellate diversity, originations, and extinctions and their significance. Canadian Journal of Botany, 74, 1687-1694.

MARTIN, F. 1993. Acritarchsa Review. Biological Reviews, 68, 475-537.

MARTINI, E. Standard Tertiary and Quaternary calcareous nannoplankton zonation. Proceedings of the Second Planktonic Conference, Roma 1970, 1971. Tecnoscienza, 739-785.

MATEAR, R., HIRST, A. \& MCNEIL, B. 2000. Changes in dissolved oxygen in the Southern Ocean with climate change. Geochemistry, Geophysics, Geosystems, 1(11), 1050.

MEEHL, G. A., COVEY, C., TAYLOR, K. E., DELWORTH, T., STOUFFER, R. J., LATIF, M., MCAVANEY, B. \& MITCHELL, J. F. 2007a. The WCRP CMIP3 multimodel dataset: A new era in climate change research. Bulletin of the American Meteorological Society, 88, 1383-1394.

MEEHL, G. A., STOCKER, T. F., COLLINS, W. D., FRIEDLINGSTEIN, A., GAYE, A. T., GREGORY, J. M., KITOH, A., KNUTTI, R., MURPHY, J. M. \& NODA, A. 2007b. Global climate projections. IPCC, 2007: Climate Change 2007: the physical science basis. contribution of Working Group I to the Fourth Assessment Report of the Intergovernmental Panel on Climate Change, 747-846.

MEYERS, P. A. 2006. Paleoceanographic and paleoclimatic similarities between Mediterranean sapropels and Cretaceous black shales. Palaeogeography, Palaeoclimatology, Palaeoecology, 235, 305-320.

MEYERS, S. R., SAGEMAN, B. B. \& HINNOV, L. A. 2001. Integrated quantitative stratigraphy of the Cenomanian-Turonian Bridge Creek Limestone Member using evolutive harmonic analysis and stratigraphic modeling. Journal of Sedimentary Research, 71, 628-644.

MUDIE, P., LEROY, S., MARRET, F., GERASIMENKO, N., KHOLEIF, S., SAPELKO, T. \& FILIPOVAMARINOVA, M. 2011. Nonpollen palynomorphs: indicators of salinity and environmental change in the Caspian-Black Sea-Mediterranean corridor. Geological Society of America Special Papers, 473, 89-115.

MURPHY, J. M., SEXTON, D. M., BARNETT, D. N., JONES, G. S., WEBB, M. J., COLLINS, M. \& STAINFORTH, D. A. 2004. Quantification of modelling uncertainties in a large ensemble of climate change simulations. Nature, 430, 768-772. 
PANCOST, R. D., TAYLOR, K. W., INGLIS, G. N., KENNEDY, E. M., HANDLEY, L., HOLLIS, C. J., CROUCH, E. M., PROSS, J., HUBER, M. \& SCHOUTEN, S. 2013. Early Paleogene evolution of terrestrial climate in the SW Pacific, Southern New Zealand. Geochemistry, Geophysics, Geosystems, 14, 5413-5429.

PENAFIEL BERMUDEZ, S., TREMAIN, R. 2013. Paleontology laboratory methods manual. GNS Science Internal Report 2013/03.34 p.

POWELL, A. J., LEWIS, J. \& DODGE, J. D. 1992. The palynological expressions of postPalaeogene upwelling: a review. Geological Society, London, Special Publications, 64, 215-226.

RAFALSKA-BLOCH, J. \& CUNNINGHAM, R. 1986. Organic fades in Recent sediments of carbonate platforms: Southwestern Puerto Rico and Northern Belize. Organic geochemistry, 10, 717-724.

RAINE, J. I., BEU, A. G., BOYES, A. F., CAMPBELL, H., COOPER, R. A., CRAMPTON, J. S., CRUNDWELL, M. P., HOLLIS, C. J. \& MORGANS, H. 2015. Revised Calibration of the New Zealand Geological Timescale: NTGT2015/1. GNS Science Report 2012/39. 53 p.

REAY, M. 1993. Geology of the middle part of the Clarence Valley. Scale 1: 50 000. Institute of Geological \& Nuclear Sciences geological map, 10.

RONCAGLIA, L. \& KUIJPERS, A. 2006. Revision of the palynofacies model of Tyson (1993) based on recent high-latitude sediments from the North Atlantic. Facies, 52, 19-39.

SCHMITZ, B. \& PUJALTE, V. 2003. Sea-level, humidity, and land-erosion records across the initial Eocene thermal maximum from a continental-marine transect in northern Spain. Geology, 31, 689-692.

SCHMITZ, B. \& PUJALTE, V. 2007. Abrupt increase in seasonal extreme precipitation the Paleocene-Eocene boundary. Geology, 35, 215-218.

SLOTNICK, B., DICKENS, G., HOLLIS, C., CRAMPTON, J., PERCY STRONG, C. \& PHILLIPS, A. 2015. The onset of the early Eocene climatic optimum at branch stream, Clarence River valley, New Zealand. New Zealand Journal of Geology and Geophysics, 58, 262-280.

SLOTNICK, B. S., DICKENS, G. R., NICOLO, M. J., HOLLIS, C. J., CRAMPTON, J. S., ZACHOS, J. C. \& SLUIJS, A. 2012. Large-amplitude variations in carbon cycling and terrestrial weathering during the latest Paleocene and earliest Eocene: The record at Mead Stream, New Zealand. The journal of geology, 120, 487-505.

SLUIJS, A., PROSS, J. \& BRINKHUIS, H. 2005. From greenhouse to icehouse; organic-walled dinoflagellate cysts as paleoenvironmental indicators in the Paleogene. Earth-Science Reviews, 68, 281-315.

SLUIJS, A., SCHOUTEN, S., PAGANI, M., WOLTERING, M., BRINKHUIS, H., DAMSTÉ, J. S. S., DICKENS, G. R., HUBER, M., REICHART, G.-J. \& STEIN, R. 2006. Subtropical Arctic Ocean temperatures during the Palaeocene/Eocene thermal maximum. Nature, 441, 610613.

STRONG, C., HOLLIS, C. \& WILSON, G. 1995. Foraminiferal, radiolarian, and dinoflagellate biostratigraphy of Late Cretaceous to middle Eocene pelagic sediments (Muzzle group), Mead Stream, Marlborough, New Zealand. New Zealand Journal of Geology and Geophysics, 38, 171-209.

TALLEY, S. M., COLEY, P. D. \& KURSAR, T. A. 2002. The effects of weather on fungal abundance and richness among 25 communities in the Intermountain West. BMC Ecology, 2, 7.

TAPPAN, H. N. 1980. The paleobiology of plant protists. W.H. Freeman, New York, 1028 pp. 
TYSON, R. V. 1995. Sedimentary organic matter : organic facies and palynofacies. London; New York, Chapman \& Hall. 615 p.

WATERHOUSE, H. K. 1999. Regular terrestrially derived palynofacies cycles in irregular marine sedimentary cycles, Lower Lias, Dorset, UK. Journal of the Geological Society, 156, 1113-1124.

WILSON, G. J. 1967. Some species of Wetzeliella Eisenack (Dinophyceae) from New Zealand Eocene and Paleocene strata. New Zealand Journal of Botany, 5(4), 469-97.

WILSON, G. J. 1988. Paleocene and Eocene dinoflagellate cysts from Waipawa, Hawkes Bay, New Zealand. New Zealand Geological Survey Paleontological Bulletin 57. 96 p.

ZACHOS, J. C., DICKENS, G. R. \& ZEEBE, R. E. 2008. An early Cenozoic perspective on greenhouse warming and carbon-cycle dynamics. Nature, 451, 279-283.

ZACHOS, J. C., MCCARREN, H., MURPHY, B., RÖHL, U. \& WESTERHOLD, T. 2010. Tempo and scale of late Paleocene and early Eocene carbon isotope cycles: Implications for the origin of hyperthermals. Earth and Planetary Science Letters, 299, 242-249.

ZACHOS, J., PAGANI, M., SLOAN, L., THOMAS, E. \& BILLUPS, K. 2001. Trends, rhythms, and aberrations in global climate $65 \mathrm{Ma}$ to present. Science, 292, 686-693.

ZONNEVELD, K. A. F., CHEN, L., MÖBIUS, J. \& MAHMOUD, M. S. 2009. Environmental significance of dinoflagellate cysts from the proximal part of the Po-river discharge plume (off southern Italy, Eastern Mediterranean). Journal of Sea Reaseach, 62(4), 189-213. 


\section{Appendix A: Paleogene Time Scale}

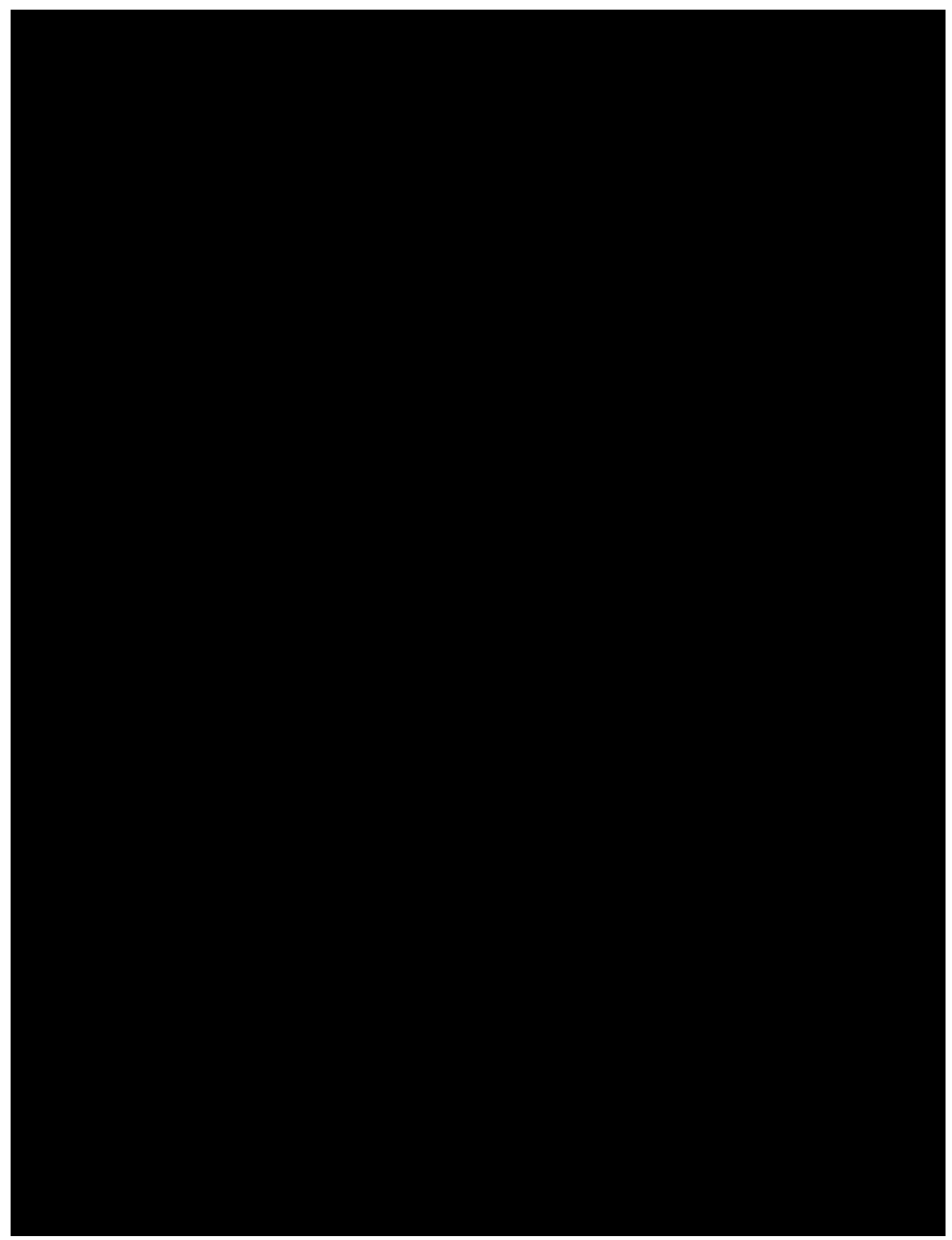

Paleogene timescale with 2015 calibration New Zealand stages. Image after Raine et al. (2015). 


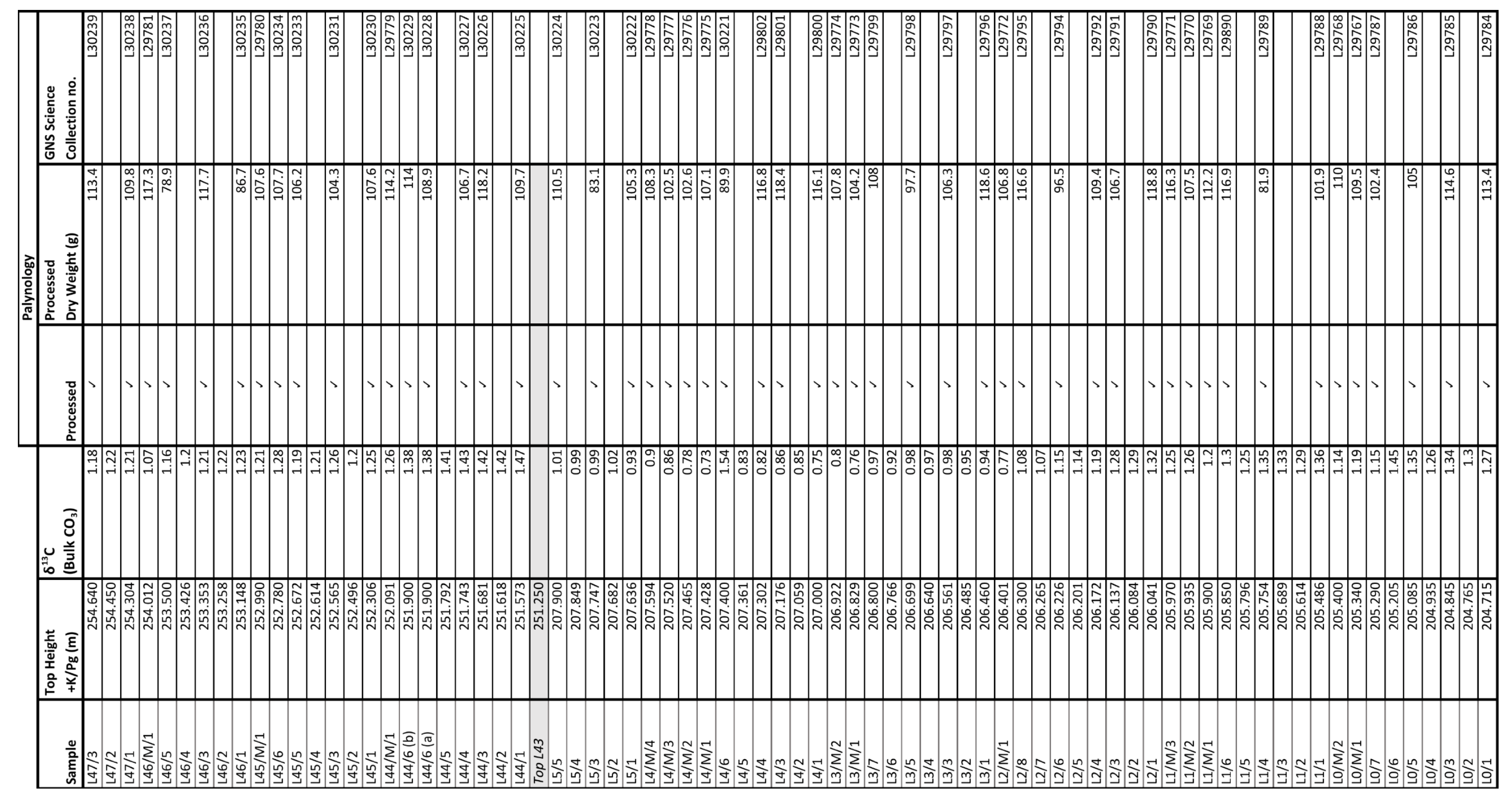




\section{Appendix C: Taxonomic List of Marine Palynomorphs}

The following taxa were identified during the course of this study. Nomenclature follows Fensome and Williams, 2004 (the "Lentin and Williams Index") where full references may be found.

Achomosphaera sp.

Achomosphaera crassipellis (Deflandre and Cookson, 1955) Stover and Evitt, 1978

Cerodinium dartomooria (Cookson and Eisenack, 1965a) Lentin and Williams, 1987

Cerodinium sp.

Charlesdowniea coleothrypta (Williams and Downie, 1966b) Lentin and Vozzhennikova, 1989

Cordosphaeridium cf. inodes (Klumpp, 1953) Eisenack, 1963b

Cordosphaeridium fibrospinum Davey and Williams, 1966

Cymatiosphaera sp.

Deflandrea convexa Wilson, 1988

Deflandrea robusta Deflandre and Cookson, 1955

Deflandrea truncata Stover 1974

Diphyes colligerum (Deflandre and Cookson, 1955) Cookson 1965a

Dracodinium sp. A

Remarks: This form appears to be identical to Dracodinium sp. A from Crouch (2001)

Dracodinium sp. B

Remarks: Form displays elongate pericyst lengthwise, with no apparent parasutural ornamentation

Dracodinium waipawaense (Wilson, 1967c) Costa and Downie, 1979 
Fibrocysta bipolaris (Cookson and Eisenack, 1965b) Stover and Evitt, 1978

?Glaphyrocysta sp. A

?Glaphyrocysta sp. B

Homotryblium tasmaniense Cookson and Eisenack, 1967a

Hystrichokolpoma bullatum Wilson 1988

Hystrichokolpoma spinosum Wilson 1988

Hystrichokolpoma spinosum type

Remarks: similar to $H$. spinosum, with much shorter precingular, and postcingular processes.

Hystrickosphaeridium tubiferum (Ehrenberg, 1837b) Deflandre, 1937b

Hystrickosphaeridium tubiferum subs. brevispinum (Davey and Williams, 1966b) Lentin and Williams, 1973

Impagidinium cassiculum Wilson 1988

Impagidinium crassimuratum Wilson 1988

Impagidinium dispertitium (Cookson and Eisenack, 1965a) Stover and Evitt, 1978

Impagidinium cf.dispertitum (Cookson and Eisenack, 1965a) Stover and Evitt, 1978

Impagidinium maculatum (Cookson and Eisenack, 1961b) Stover and Evitt, 1978

Kenleyeia type

Lejeunecysta sp.

Lingulodinium machaerophorum (Deflandre and Cookson, 1955) Wall 1967

Melitasphaeridium pseudocurvaratum (Morgenroth, 1966a) Bujak et al., 1966a

Membranophoridium perforatum Wilson 1988

Operculodinium spp.

Paleocystodinium sp. 
Phthanoperidinium sp.

Pterospermella sp.

Pyxidinopsis spp.

Rottnestia borussica (Eisenack, 1954b) Cookson and Eisenack, 1961b

Samlandia delicata Wilson 1988

Schematophora obscura Wilson 1988

Schematophora type

Remarks: Morpholigically similar to Schematophora obscura, with two antapical horns.

Spiniferites spp.

Spongodinium type

Thalassiphora pelagica; (Eisenack, 1954) Eisenack and Gocht, 1960

Turbioshpaera sp.

Unknown A

Wetzeliella sp.

Wilsonidium ornatum; (Wilson, 1967c) Lentin and Williams, 1976 
Appendix D: Plates

\title{
Plate I
}

\author{
Achomosphaera crassipellis
}

1 \& 2: L46/M/1, slide: L29781/1, EF: B38/4

Cerodinium dartmooria

3 \& 4: L47/1, slide: L30238/1, EF: Q35/2

Achomosphaera type

5: L44/M/1, slide: L29779/1, EF: P39/4

Cerodinium sp.

6: L46/M/1, slide: L29781/1, EF: K46/2

Charlesdowneia coleothrypta

7 \& 8: L114/M, slide: L22900/1, EF: V40/2 


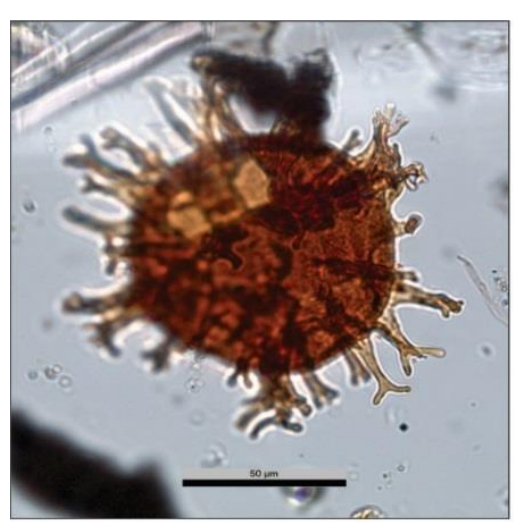

1

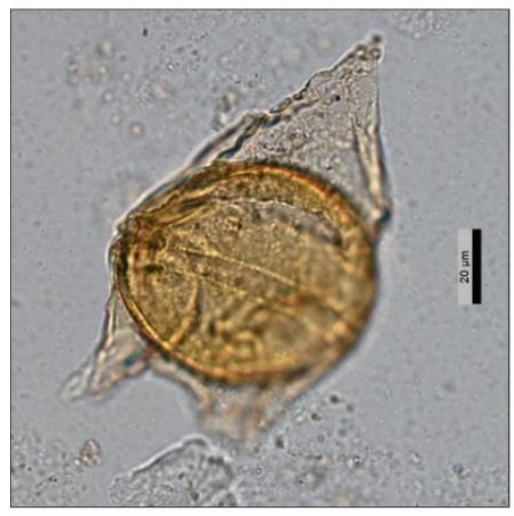

3

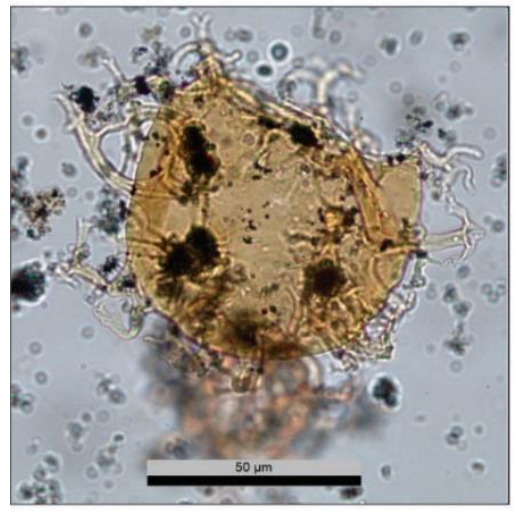

5

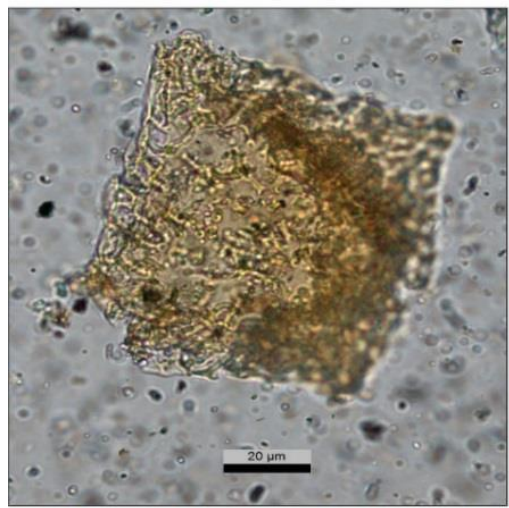

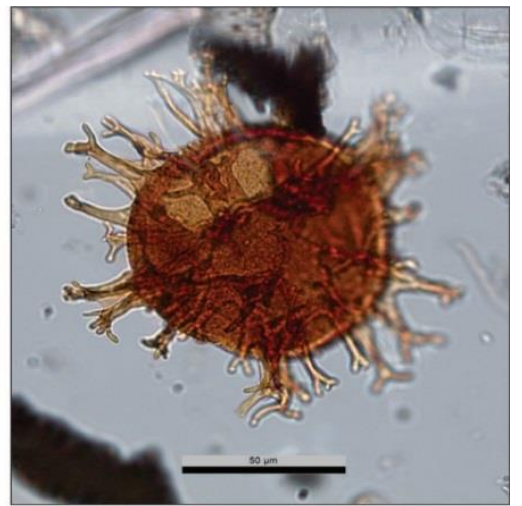

2

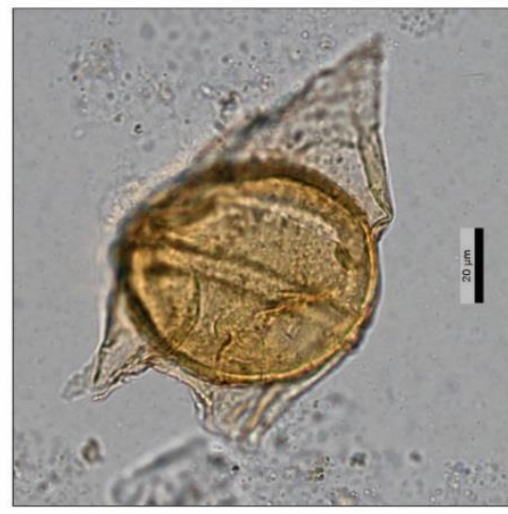

4

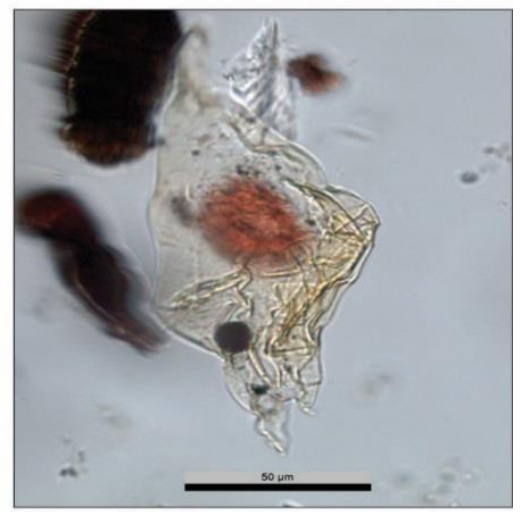

6

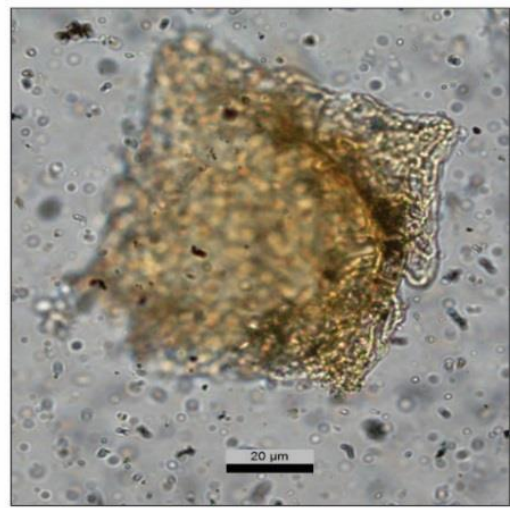

8 


\section{Plate II}

Cordosphaeridium cf.inodes

1 \& 2: L45/M/1, slide: L29780/1, EF: O34/4

Cordosphaeridium fibrospinosum

3 \& 4: L45/6, slide: L30234/1, EF: X41/1

\section{Deflandrea robusta}

5: L5/5, slide: L30224/1, EF: T29/1

6: LO/3, slide: L29785/1, EF: K37/4

Deflandrea convexa

7: L4/4, slide: L290801/3, EF: X30/4

Deflandrea truncata

8: L45/M/1, slide: L29780/1, EF: H41/1 

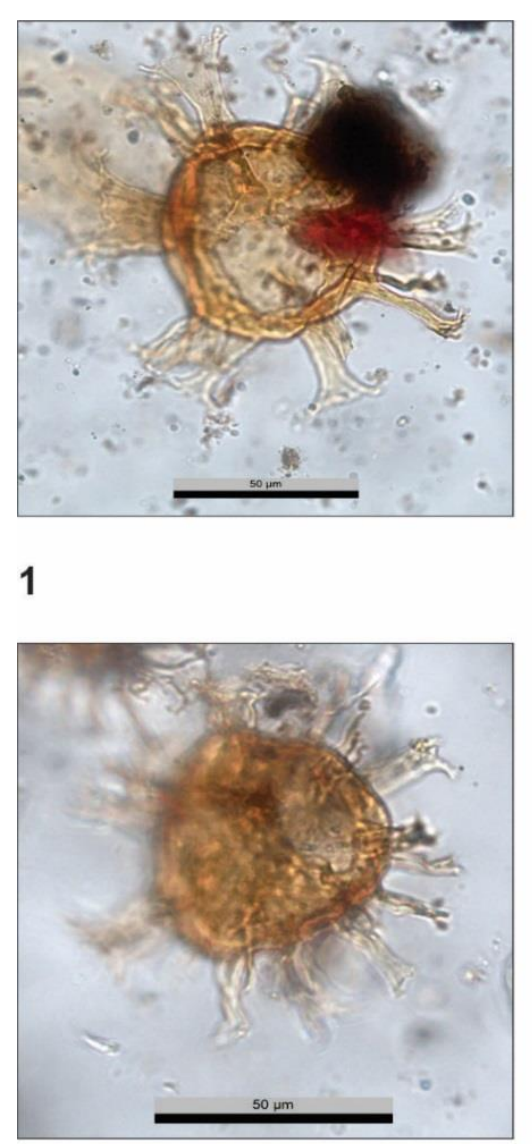

3

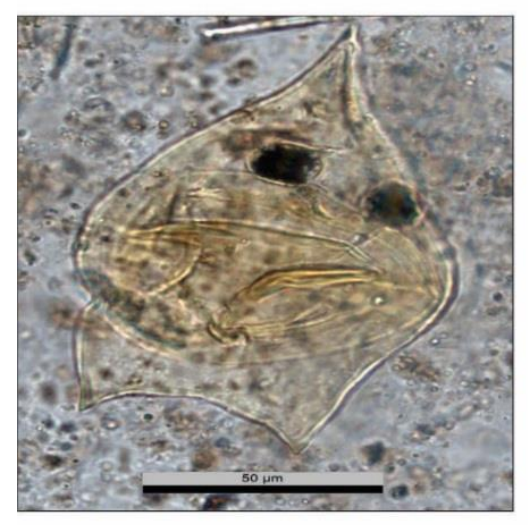

5

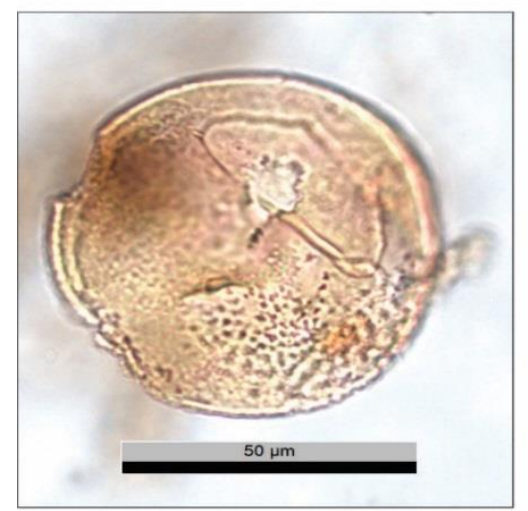

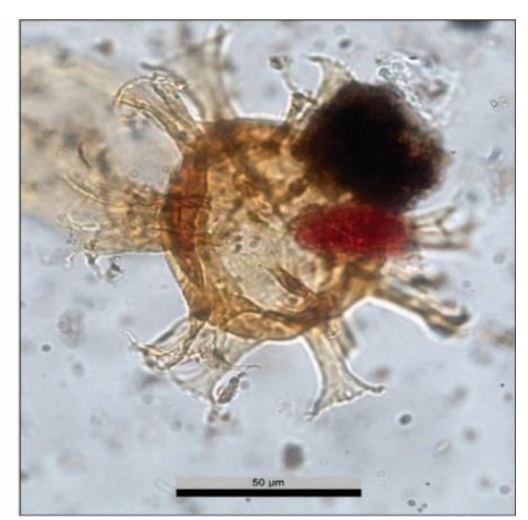

2

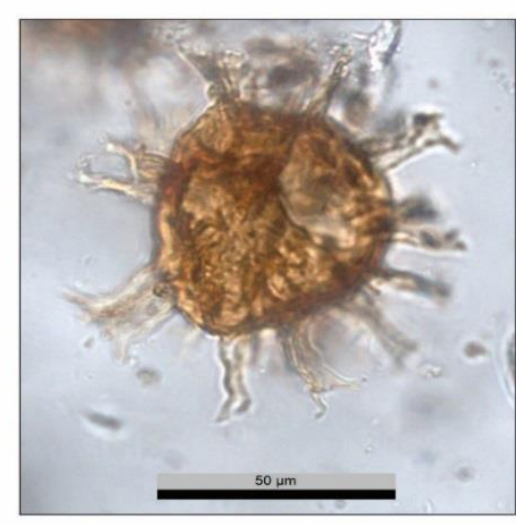

4

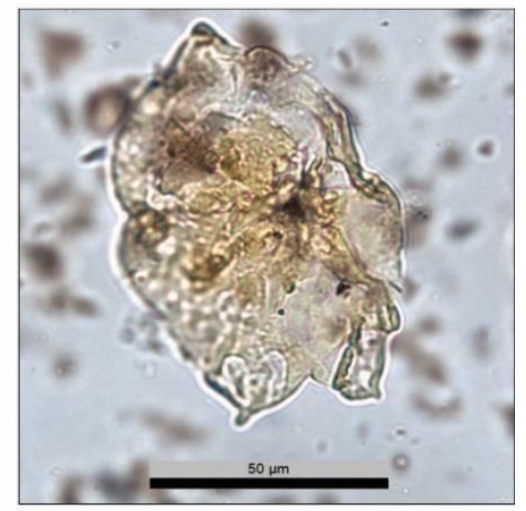

6

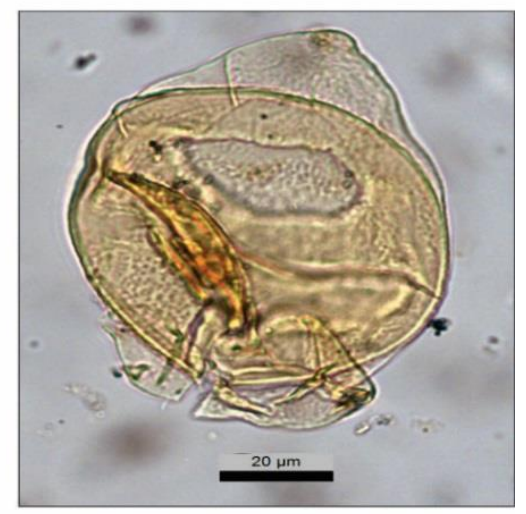

8 


\section{Plate III}

Diphyes colligerum

1 \& 2: L44/6b, slide: L30229/1, EF: P50/3

Dracodinium sp. A

3 \& 4: L5/5, slide: L30224/1, EF: H30/1

\section{Dracodinium sp. $B$}

5: L3/7, slide: L29799/1, EF: W31/4

Dracodinium waipawaense

6: L28, slide: L22950/2, EF: D39/4

Fibrocysta bipolaris

7 \& 8: L46/M/1, slide: L29781/2, EF: O35/2 


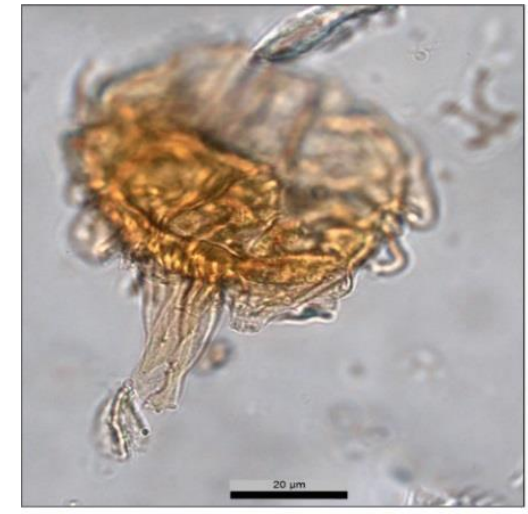

1

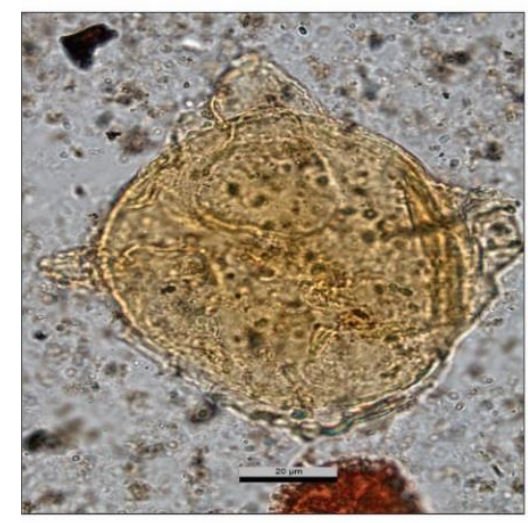

3

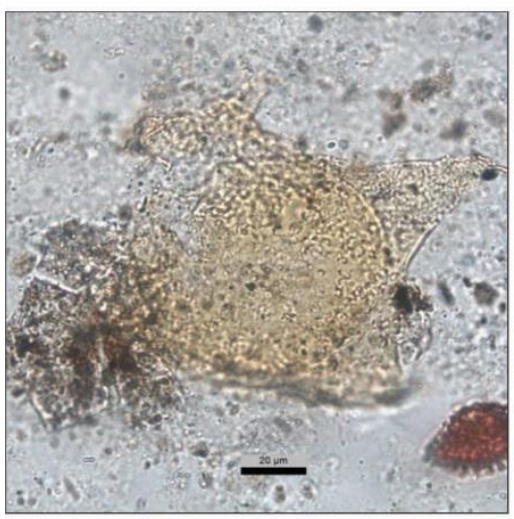

5

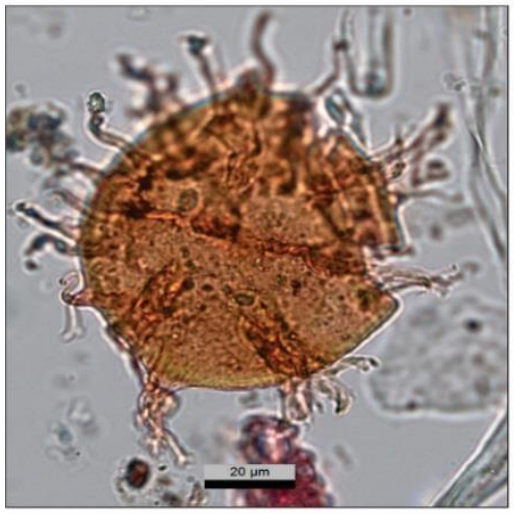

7

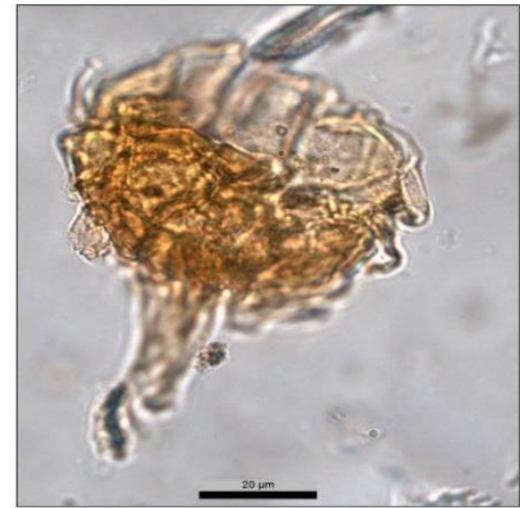

2

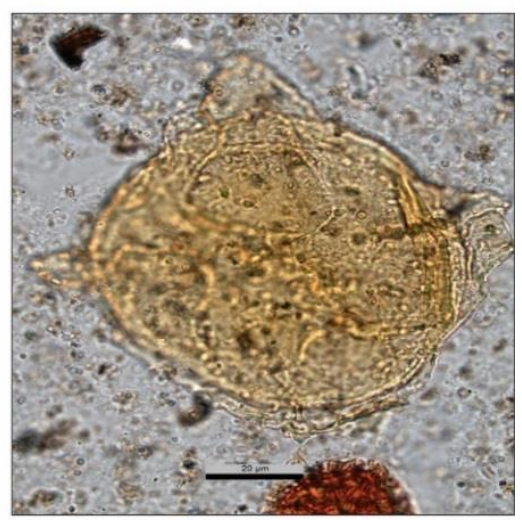

4

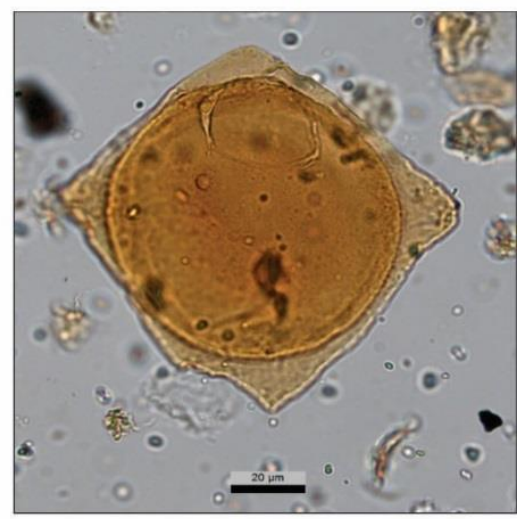

6

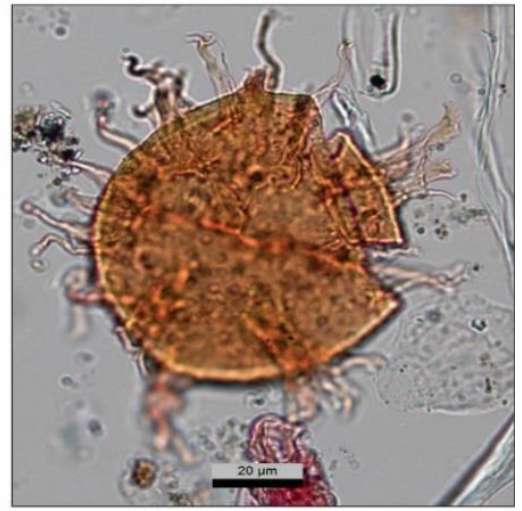

8 


\section{Plate IV}

Glaphyrocysta sp. A

1 \& 2: L44/3, slide: L30227/1, EF: N41/3

Glaphyrocysta sp. B

3 \& 4: L3/7, slide: L29799/1, EF: F46/4

Homotryblium tasmaniense

5 \& 6: L3/7, slide: L29799/1, EF: G27/3

Hystrichokolpoma bullatum

7 \& 8: L46/M/1, slide: L29781/1, EF: C36/1 


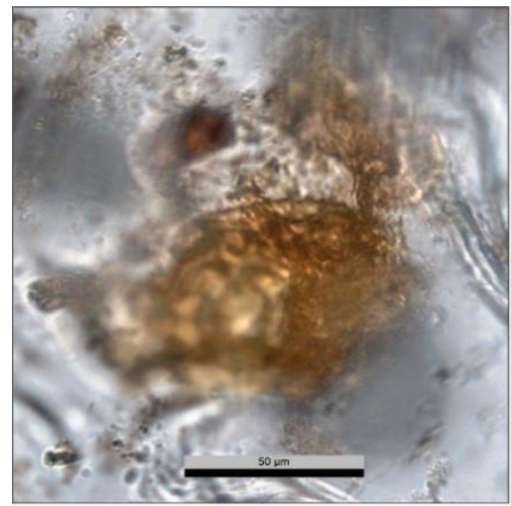

1

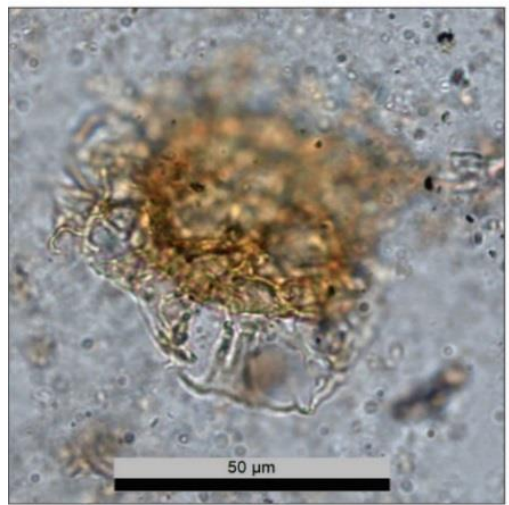

3

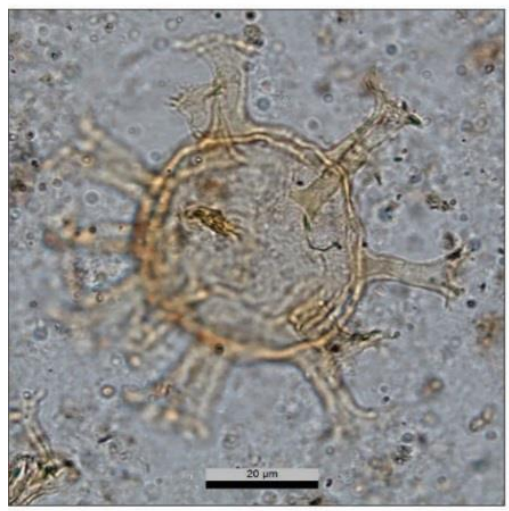

5

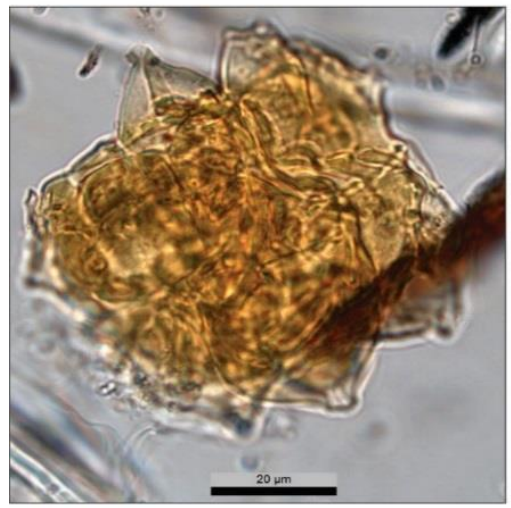

7

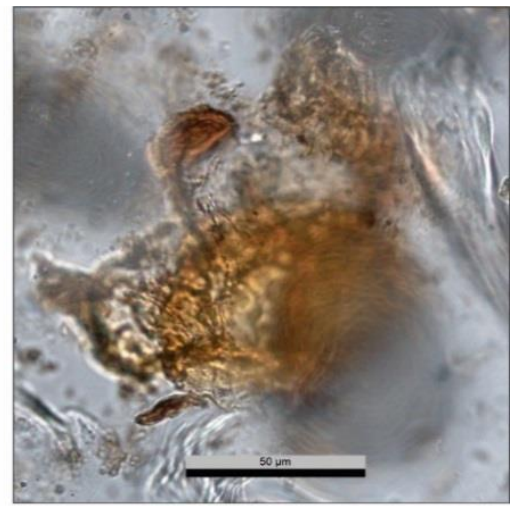

\section{2}

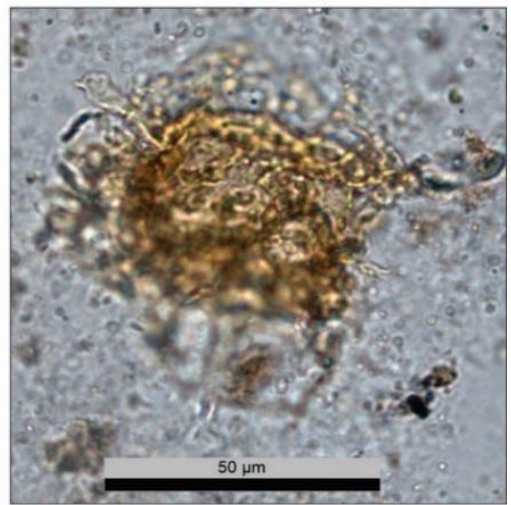

4

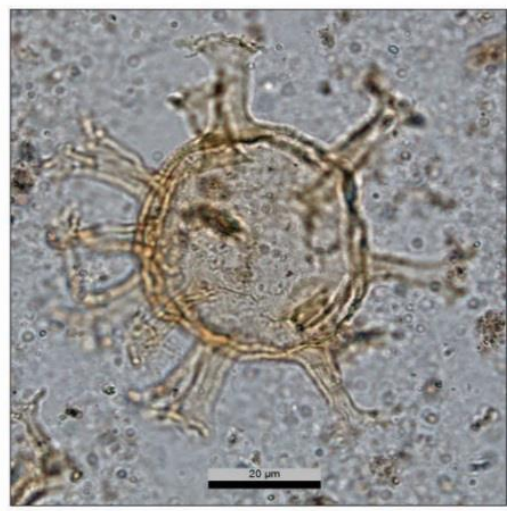

6

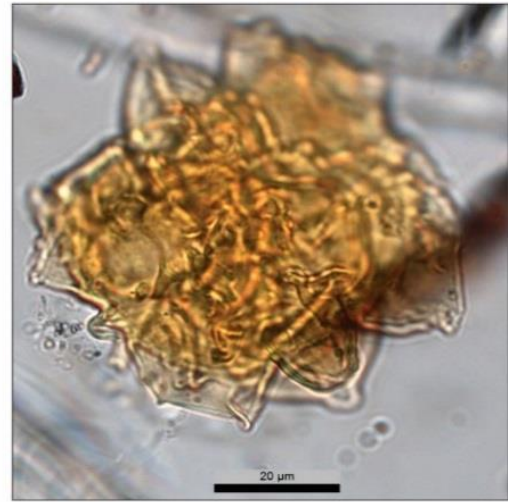

8 


\section{Plate V}

Hystrichokolpoma spinosum

1 \& 2: L44/3, slide: L30227/1, EF: U36/4

Hystrichokolpoma spinosum type

3: L4/1, slide: L29800/1, EF: E37/2

4: LO/1, slide: L29784/1

Hystrickosphaeridium tubiferum

5 \& 6: L2/8, slide: L29795/1, EF: J38/4

Hystrickosphaeridium tubiferum subs. brevispinum

7: L0/1, slide: L29784/1, EF: X42/1

8 \& 9: L44/1, slide: L30226/1, EF: J35/2 


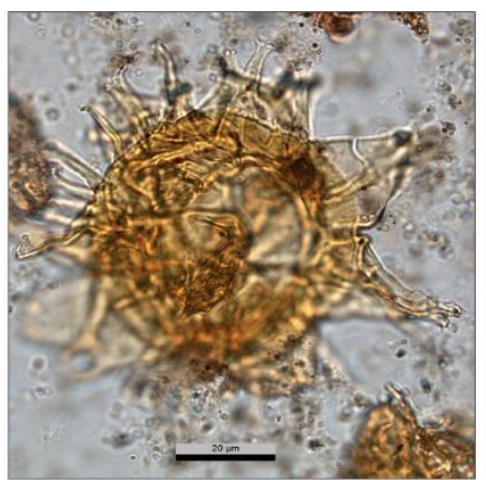

1

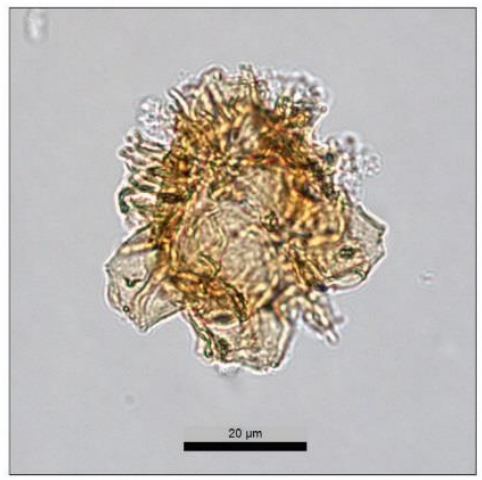

3

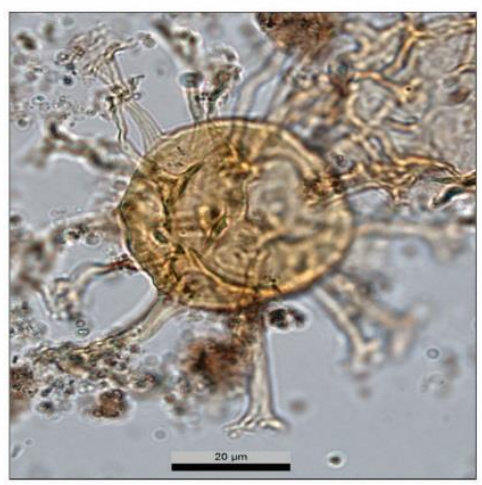

5

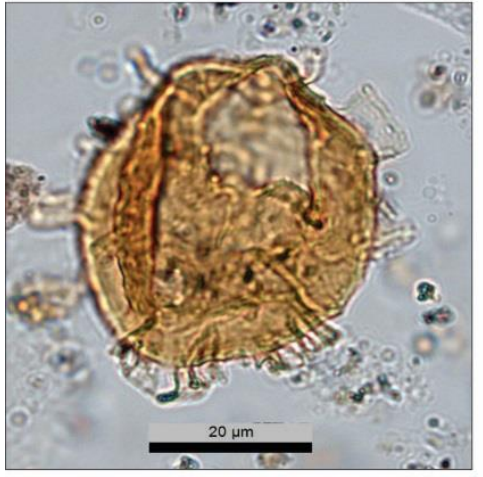

7

8

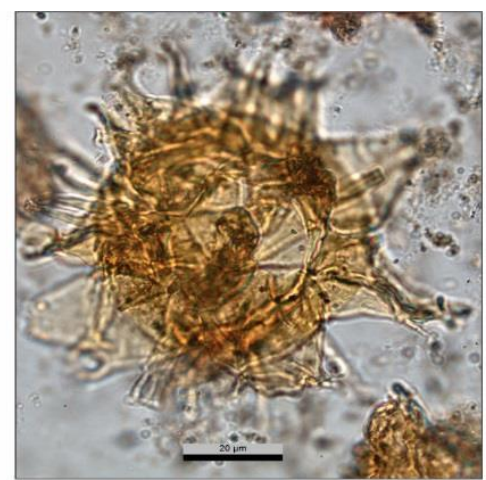

2

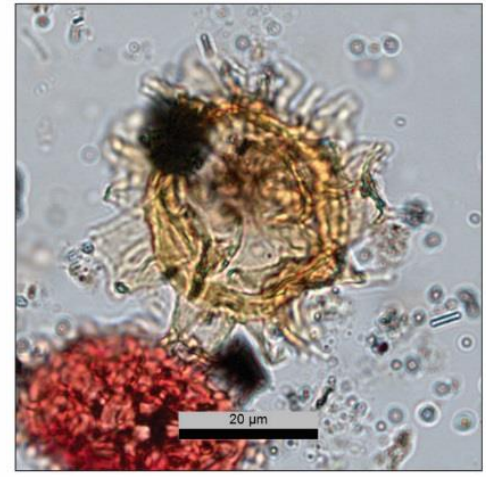

4

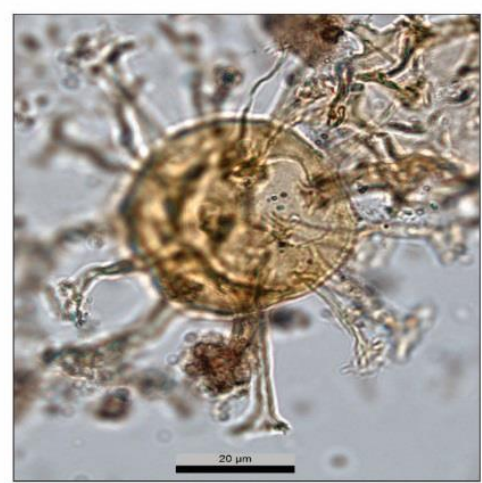

6

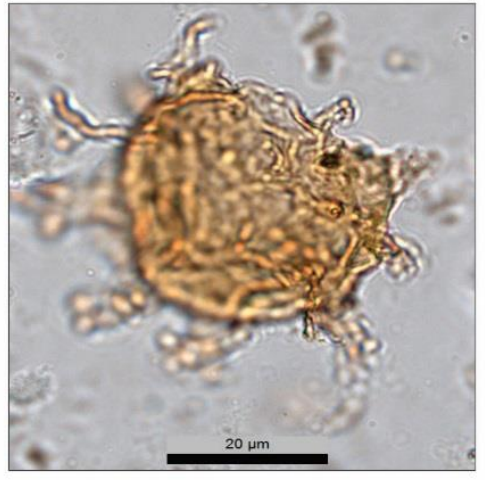

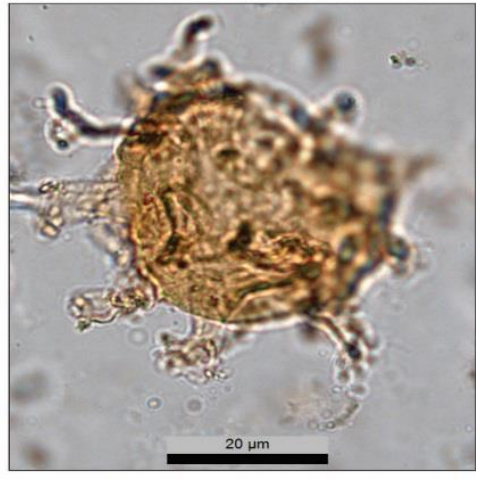

9 


\section{Plate VI}

Impagidinium cassiculum

1 \& 2: L46/3, slide: L30236/2, EF: W43/1

Imagidinium crassimuratum

3 \& 4: L3/1, slide: L29796/1, EF: V33-1

Impagidinium dispertitum

5: L4/M/3, slide: L29777/1, EF: W43/4

Impagidinium maculatum

6 \& 7: LO/3, slide: L29785/1, EF: J25/3

8 \& 9: L44/1, slide: L30226/1, EF: X49/4 


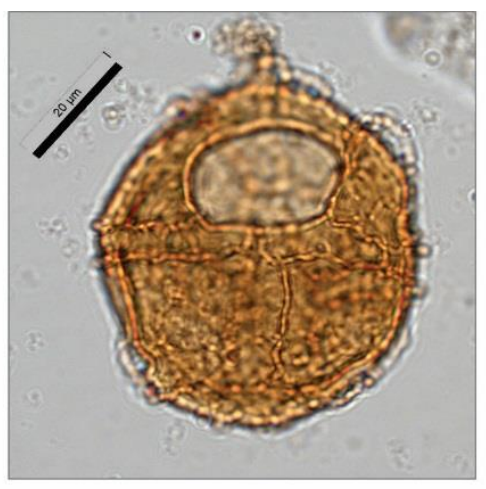

1

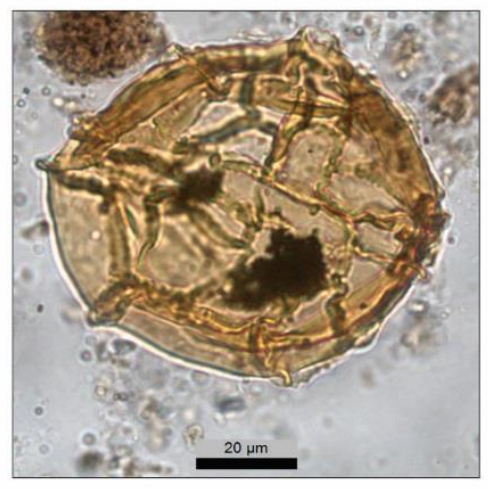

3

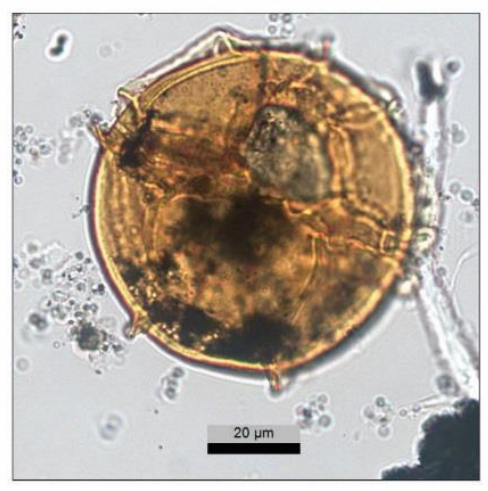

5

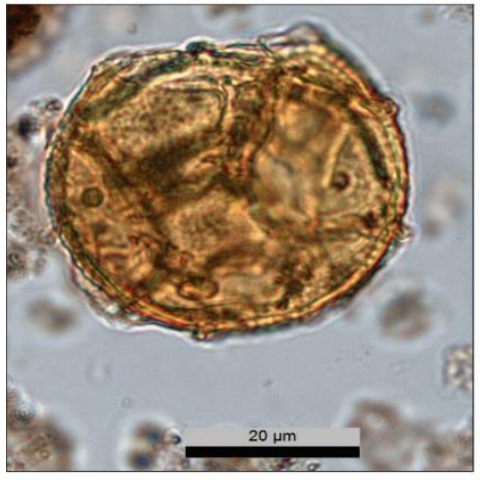

7

8

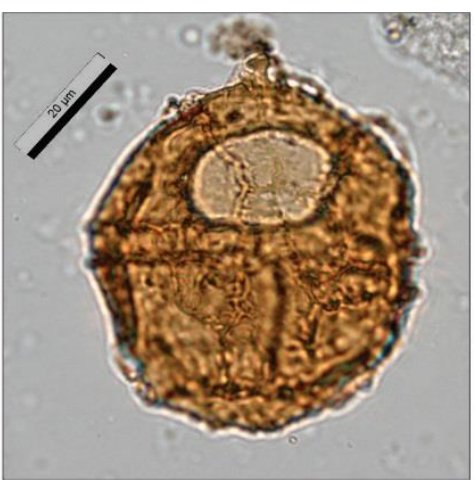

2

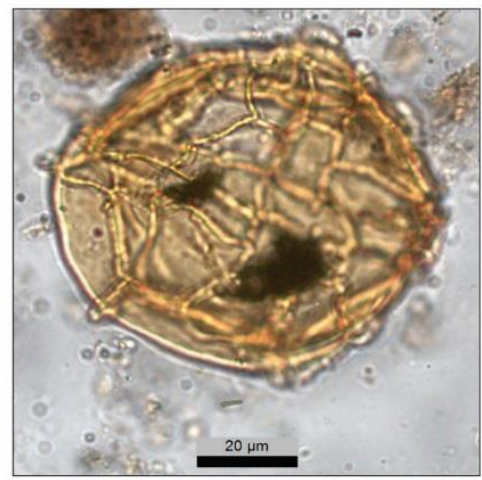

4

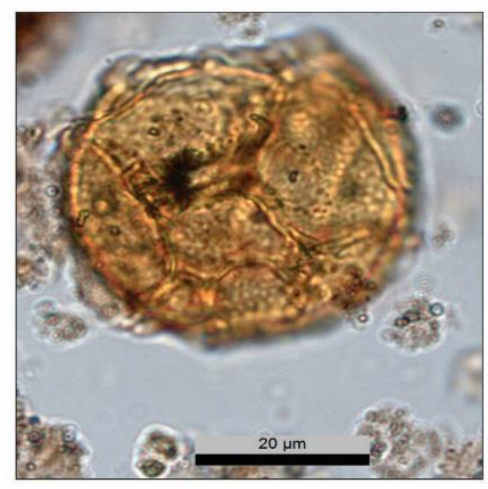

6

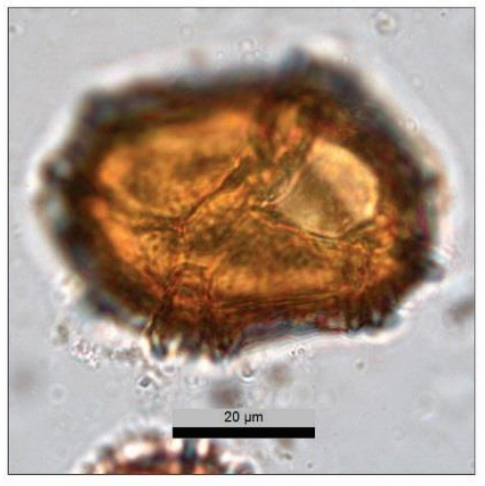

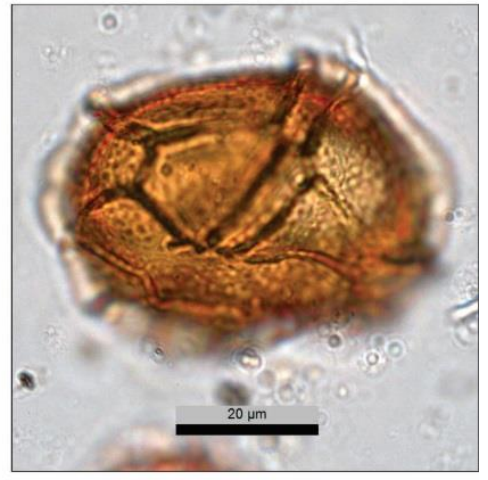

9 


\title{
Plate VII
}

\author{
Kenleyeia type
}

1 \& 2: L45/M/1, slide: L29780/1, EF: D32/1

$$
\text { Lejeunecysta sp. }
$$

3: L46/M/1, slide: L29781/2, EF: J23/1

Membranophoridium perforatum

4: L53/M, slide: L23318/1, EF: G42/2

Melitasphaeridium pseudocurvaratum

5 \& 6: L46/3, slide: L30236/2, EF: W35/1

\section{Operculodinium sp.}

7: L1/6, slide: L29890/1, EF: D45/1

8: LO/1, slide: L29784/1, EF: K48/4 


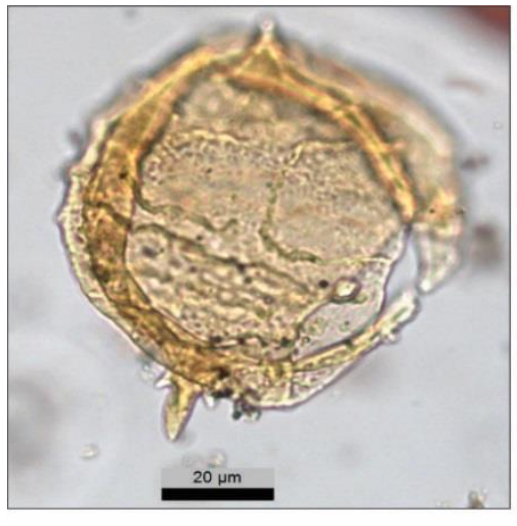

1

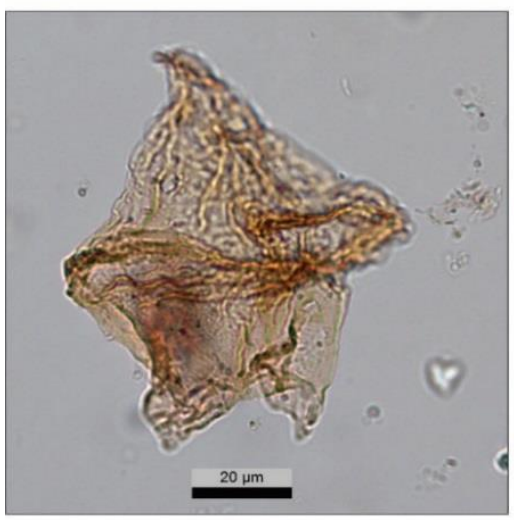

3

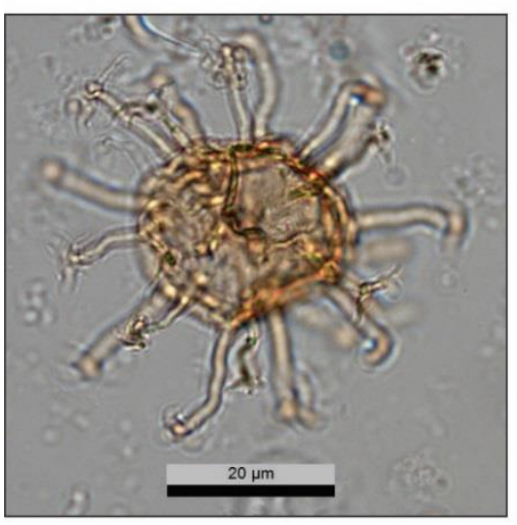

5

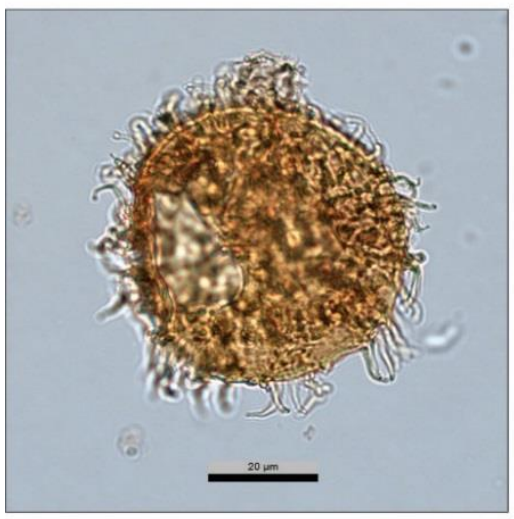

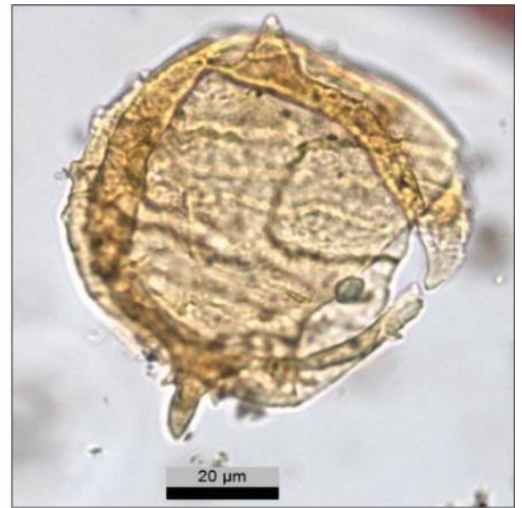

2

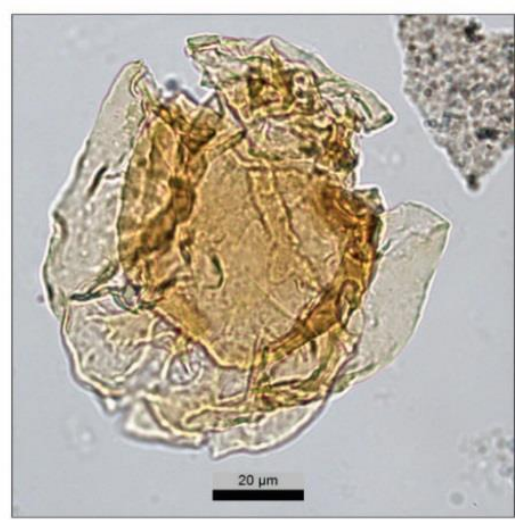

4

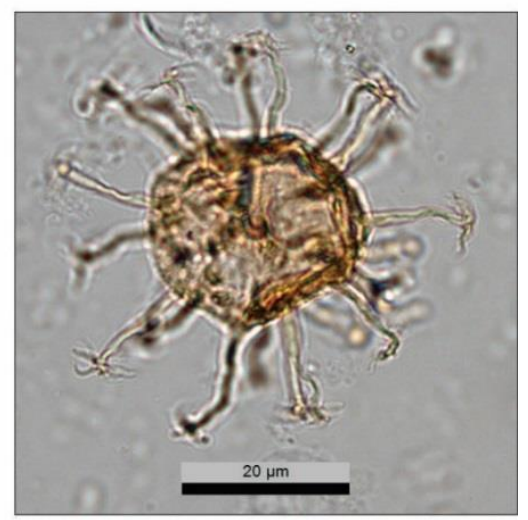

6

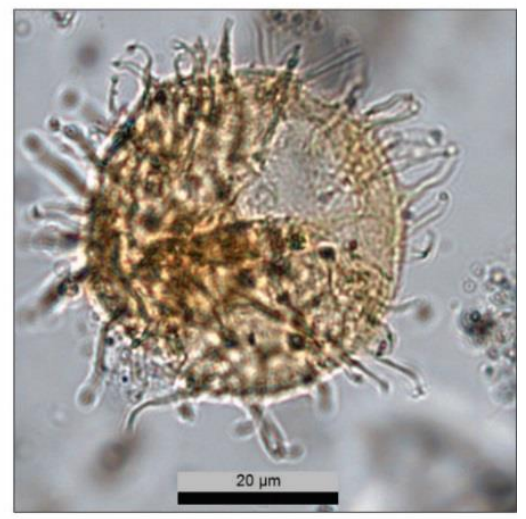

8 


\section{Plate VIII}

Paleocystodinium sp.

1: L9/M, slide: L23343/1, EF: C32/1

Phthanoperidinium ?stockmansii

2: L4/M/2, slide: L29776/1, EF: X28/2

3 \& 4: L4/M/2, slide: L29776/2, EF: K23/2

Pyxidinopsis sp.

5 \& 6: L1/6, slide: L29890/1, EF: H28/1

Rottnestia borussica

7 \& 8: L2/3, slide: L29791/1, EF: J35/2

9: L44/4, slide: L30228/1, EF: F26/4 


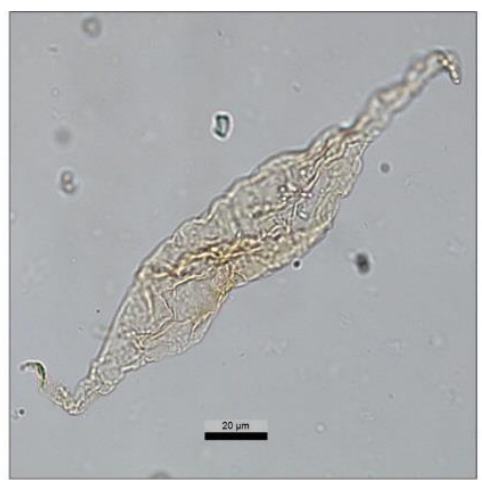

1

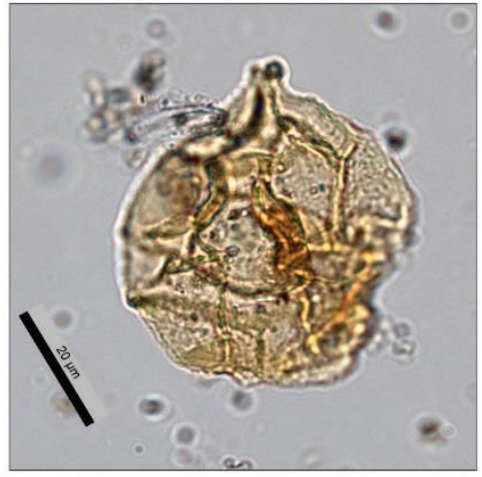

3

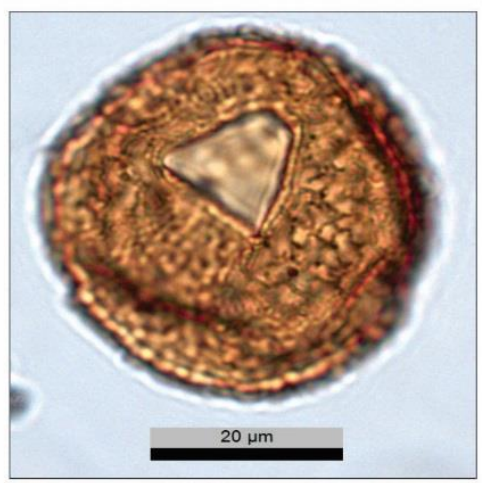

5

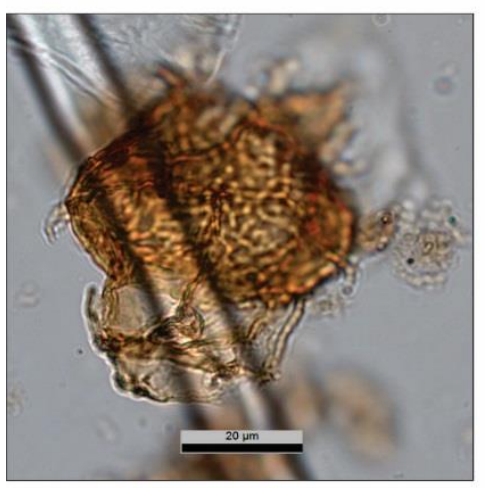

7

8

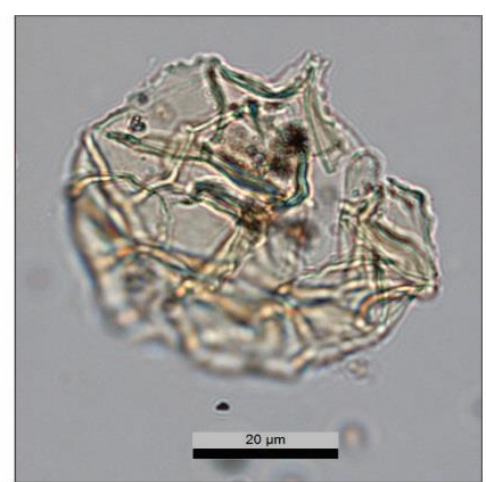

2

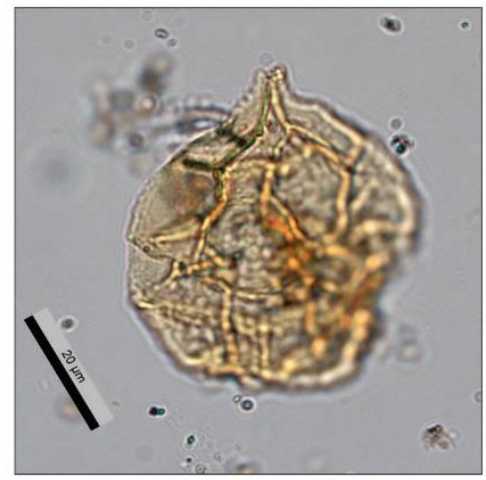

4

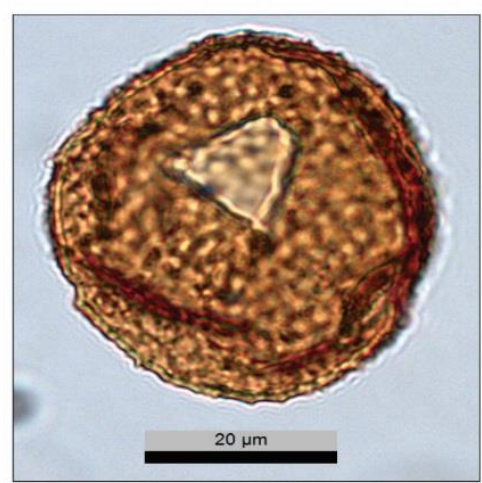

6

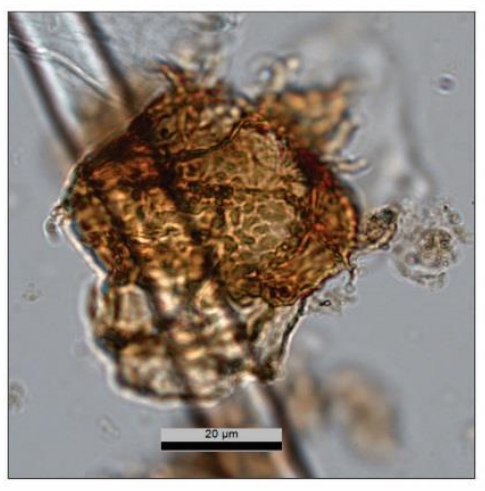

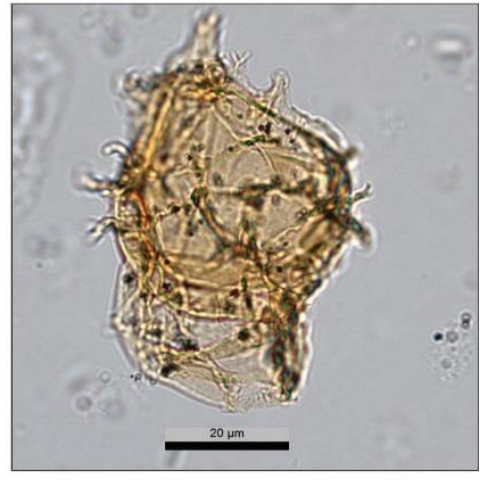

9 


\section{Plate IX}

\section{Samlandia delicata}

1 \& 2: LO/1, slide: L29784/1, EF: R32/3

\section{Schematophora type}

2 \& 3: L4/M/3, slide: L29777/1, EF: O46/1

\section{Spongodinium type}

5: L3/3, slide: L29797/1, EF: W41/4

6: L3/M/1, slide: L29773/2, EF: T36/2

\section{Schematophora obscura}

7 \& 8: L25d/M, slide: L23346/1, EF: D38/1

9: L25d/M, slide: L23346/1, EF: P41/3 


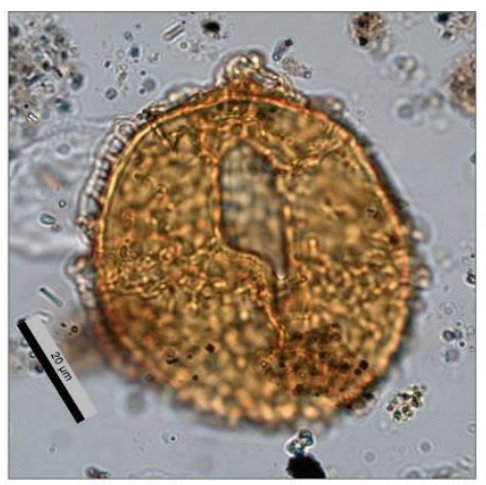

1

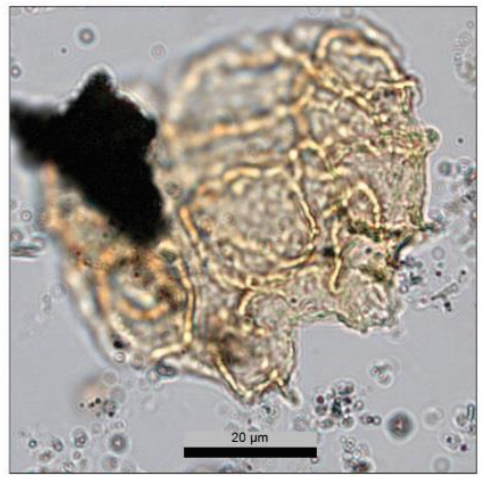

3
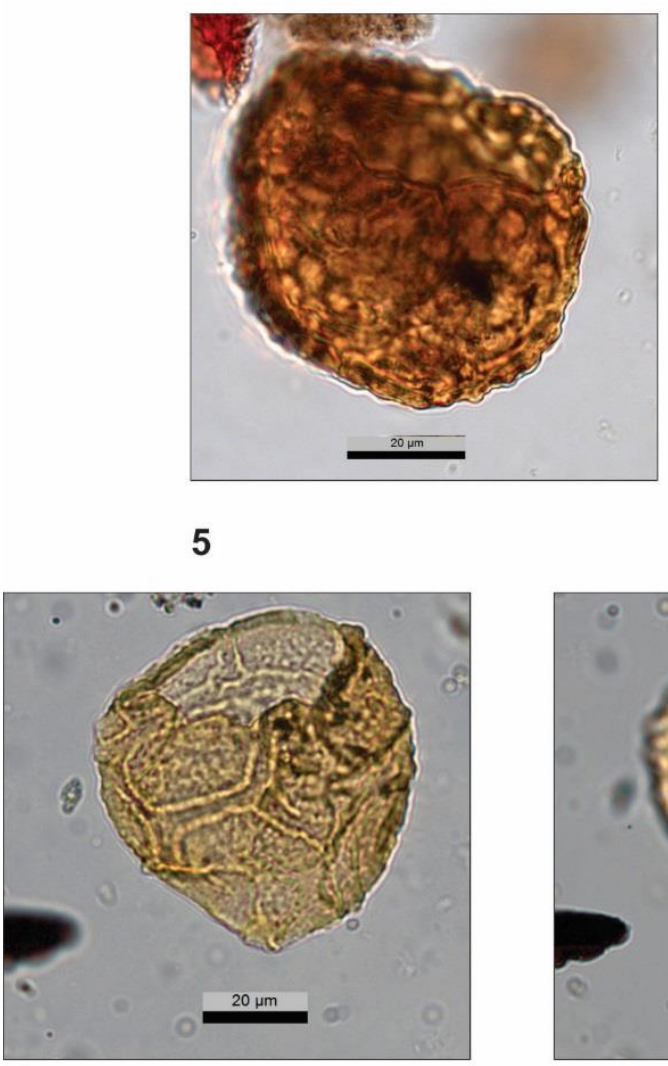

7

8

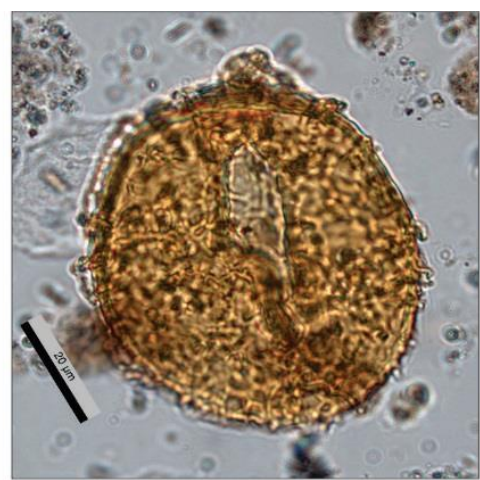

2

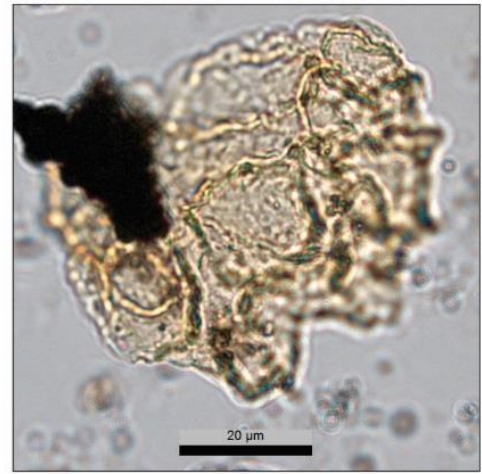

4

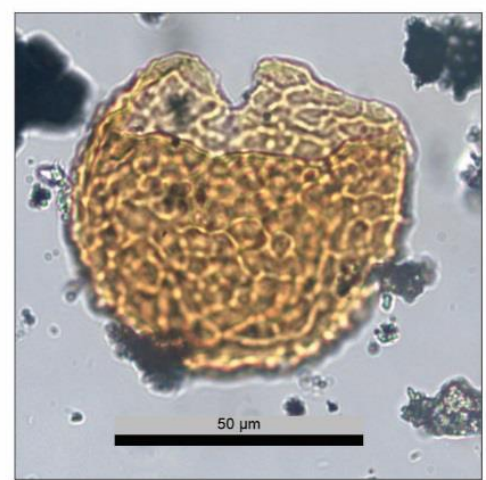

6

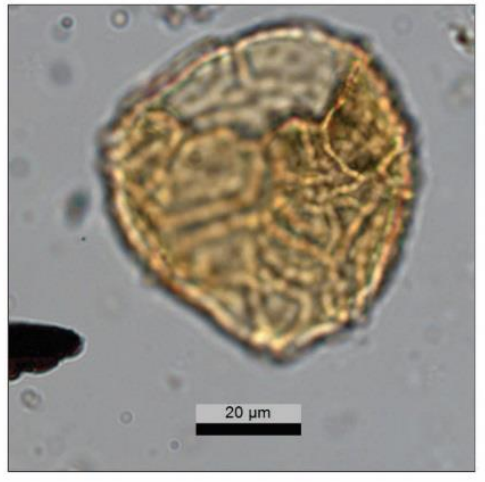

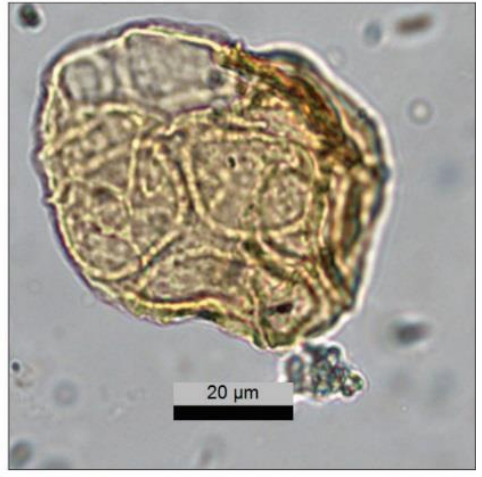

9 


\section{Plate X}

Thalassiphora pelagica

1: L44/M/1, slide: L29779/1, EF: E35/2

2: L46/M/1, slide: L29781/1, EF: G26/2

Turbiosphaera type

3 \& 4: L46/M/1, slide: L29781/2, EF: L41/1

Unknown A

5 \& 6: L46/M/1, slide: slide: L29781/1, EF: H28/3

Wetzeliella sp.

7 \& 8: L45/6, slide: L30234/2, EF: B35/4 


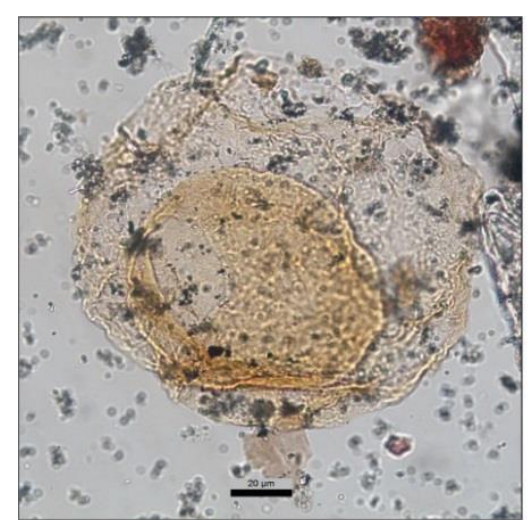

1

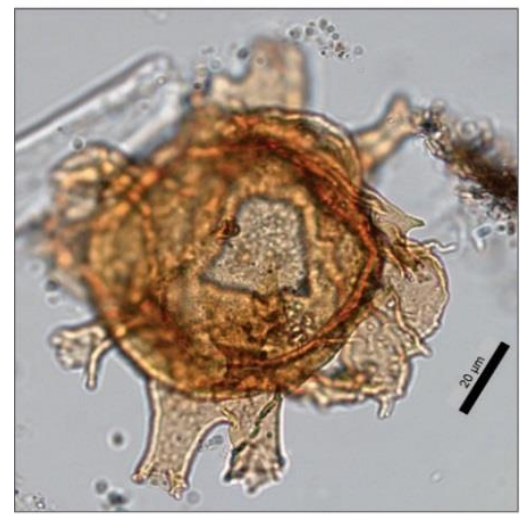

3

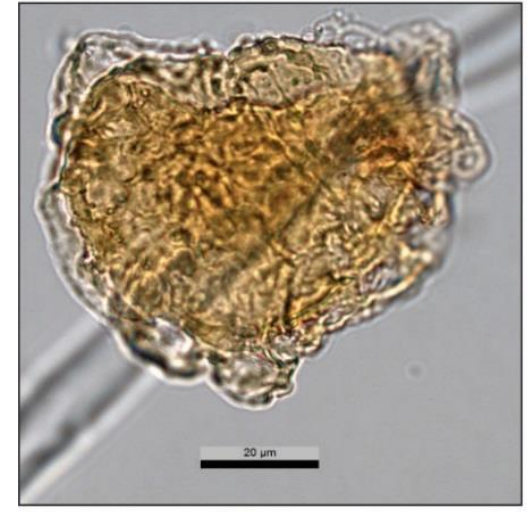

5

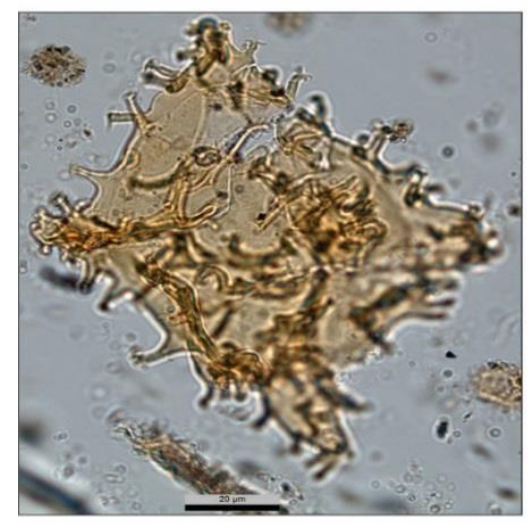

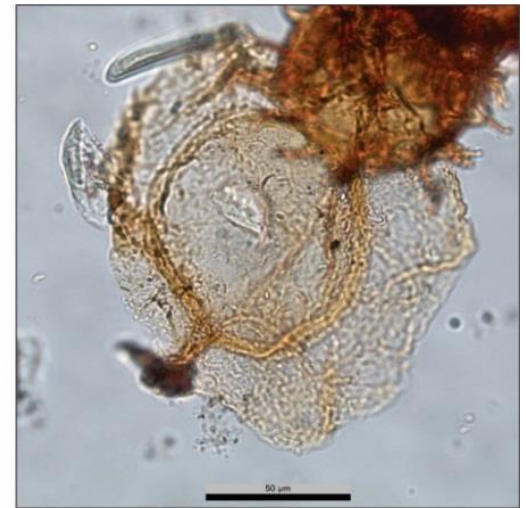

2

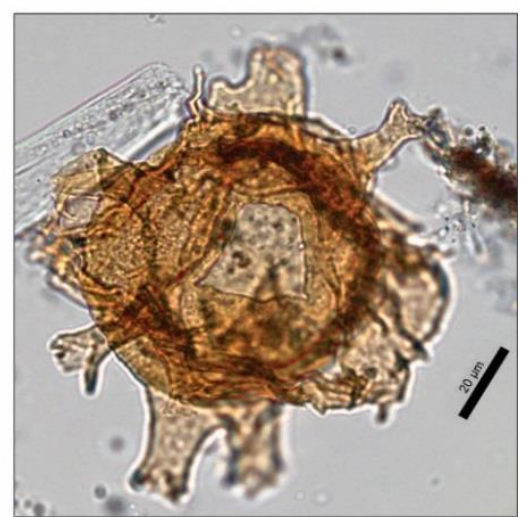

4

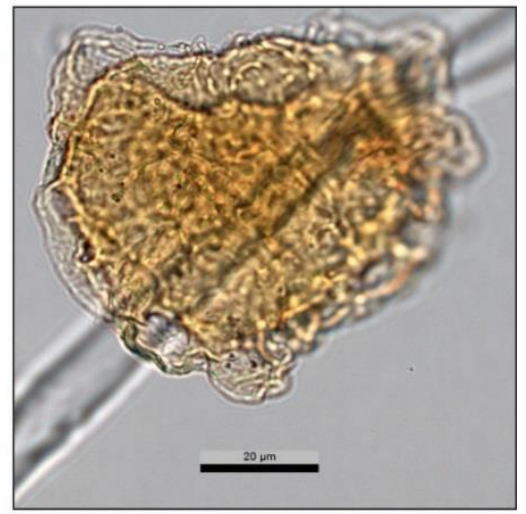

6

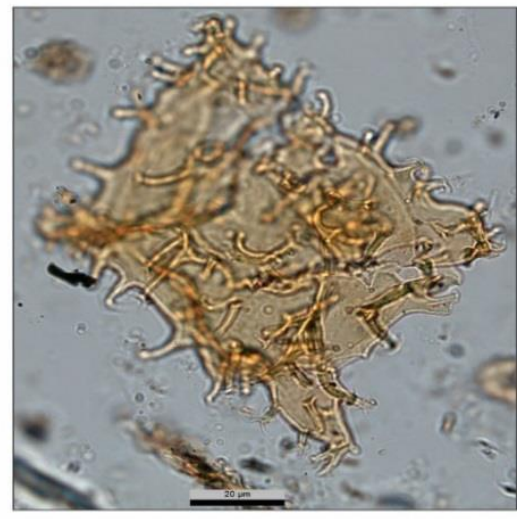

8 


\section{Plate XI}

\section{Wilsonidium ornatum}

1 \& 2: Deformed zone marl, slide: L22889/2, EF: O21/2

Cymatiosphaera sp.

3 \& 4: L44/4, slide: L30228/1, EF: D33/3

5 \& 6: Deformed zone marl, slide: L22889/1, EF: Y29/3

Pterospermella sp.

7 \& 8: L45/M/1, slide: L29780/1, EF: F31/3 


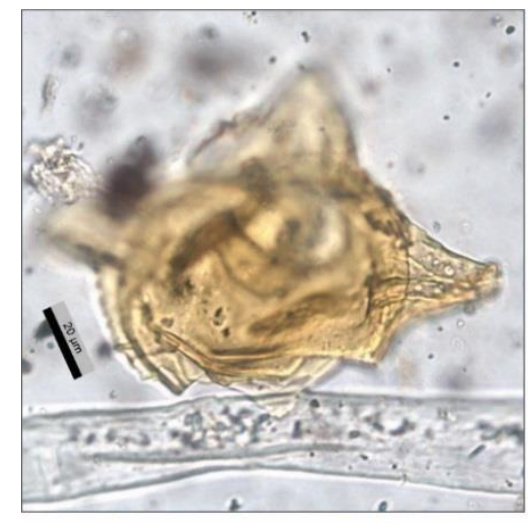

1

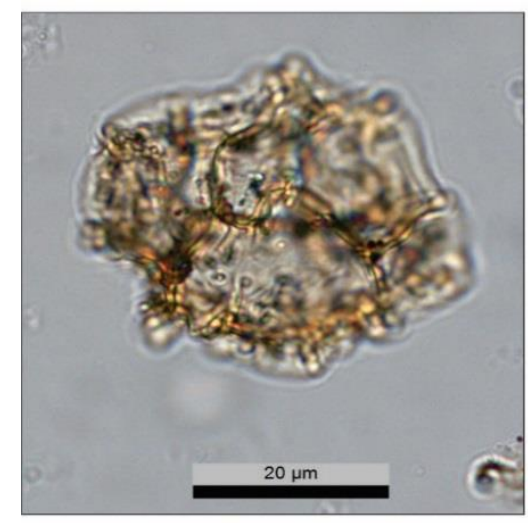

3

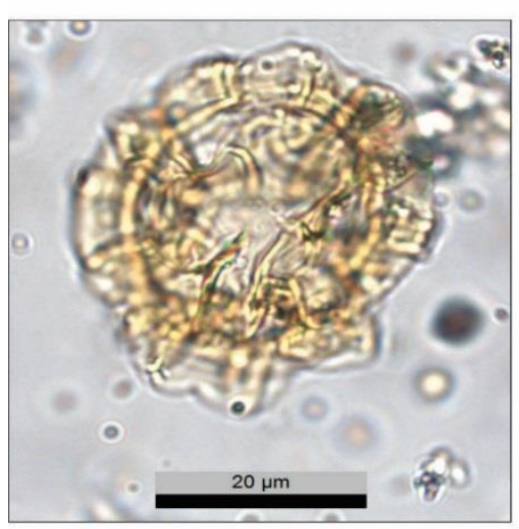

5

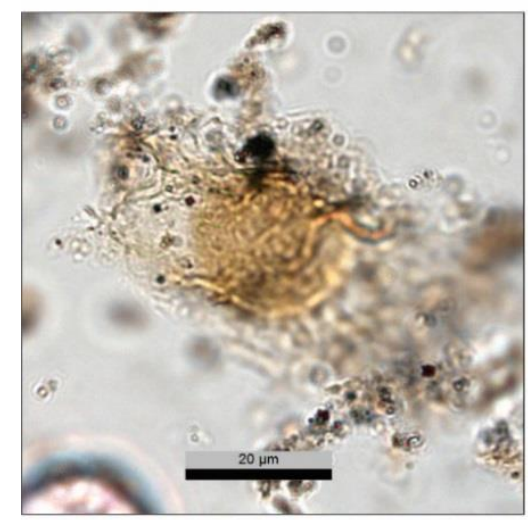

7

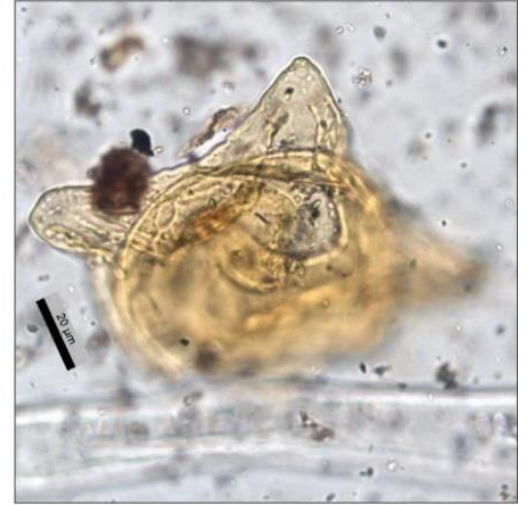

2

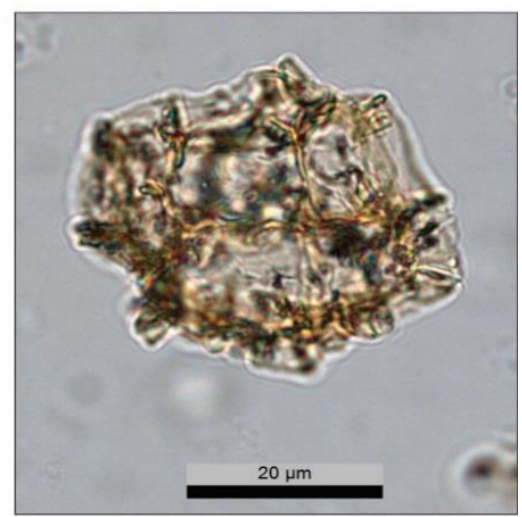

4

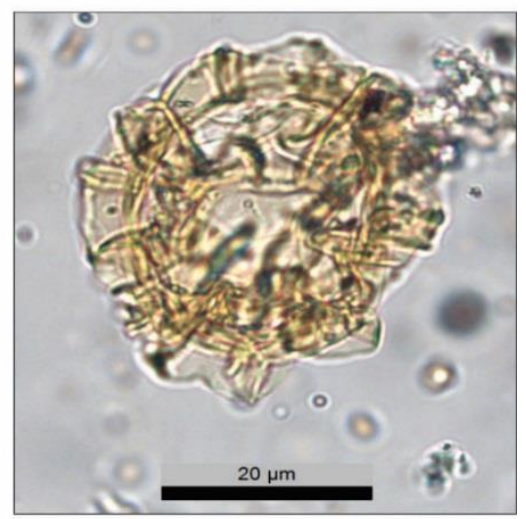

6

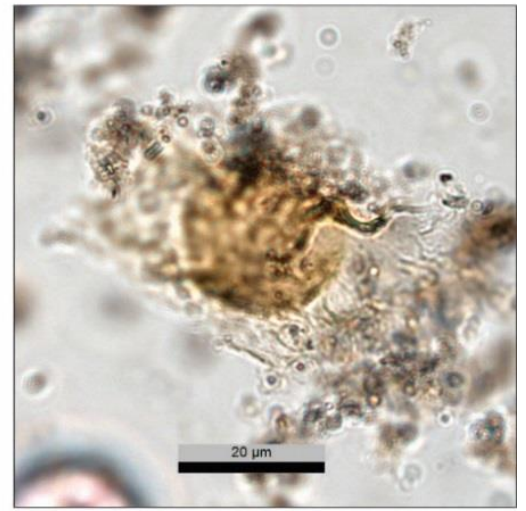

8 
Appendix E: Taxonomic Occurrences, Counts \& Abundance

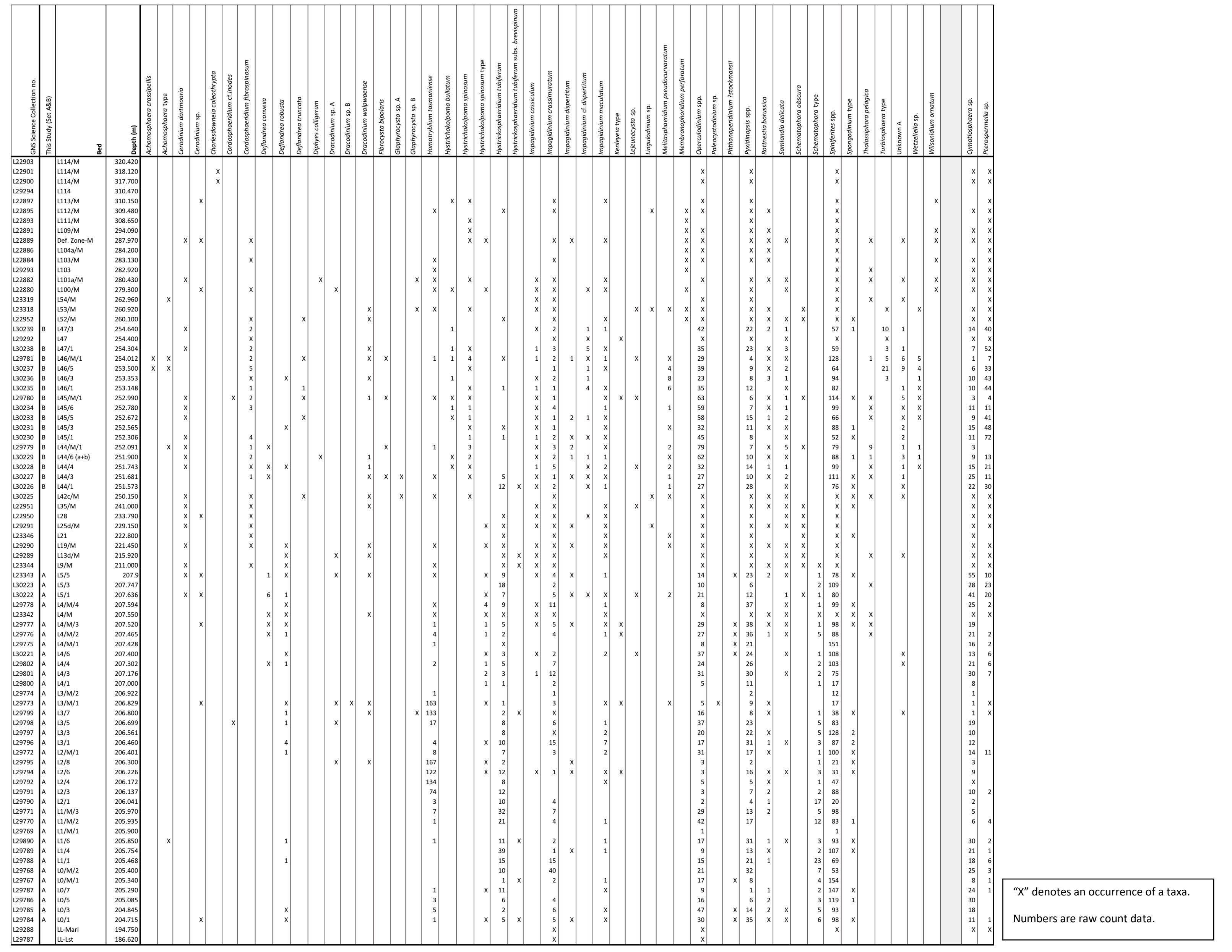




\begin{tabular}{|c|c|c|c|c|c|c|c|c|c|c|c|c|c|c|c|c|c|c|c|c|c|}
\hline 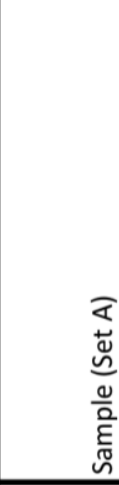 & 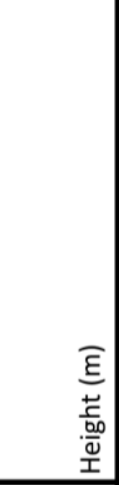 & 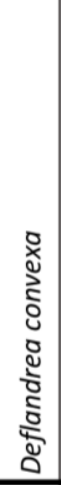 & 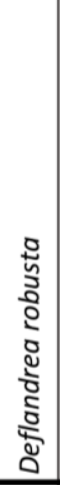 & 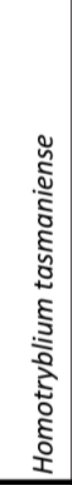 & 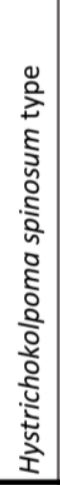 & 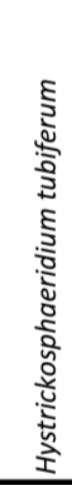 & 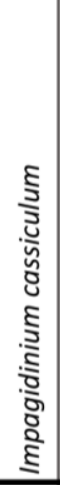 & 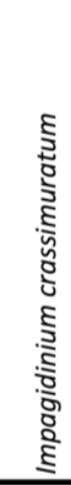 & 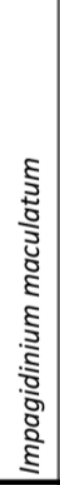 & 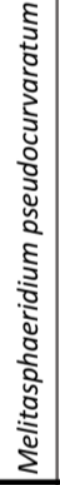 & 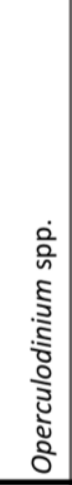 & 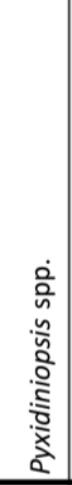 & 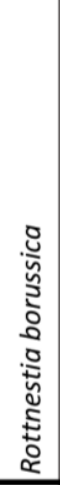 & 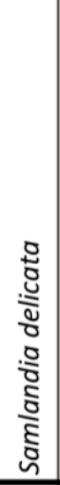 & 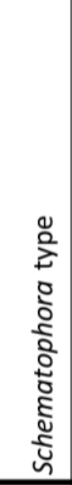 & 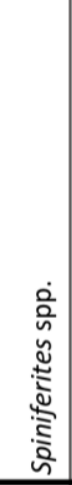 & 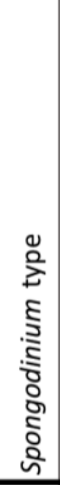 & 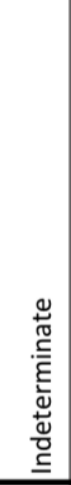 & 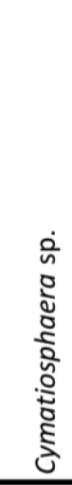 & 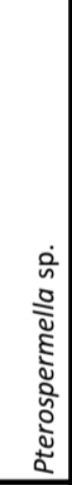 & 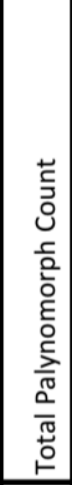 \\
\hline $\mathrm{L} 5 / 5$ & 207.900 & 0.5 & 0.0 & 0.0 & 0.0 & 4.5 & 0.0 & 2.0 & 0.5 & 0.0 & 7.0 & 11.5 & 1.0 & 0.0 & 0.5 & 39.0 & 0.0 & 1.0 & 27.5 & 5.0 & 200 \\
\hline$L 5 / 3$ & 207.747 & 0.0 & 0.0 & 0.0 & 0.0 & 9.0 & 0.0 & 1.0 & 0.0 & 0.0 & 5.0 & 3.0 & 0.0 & 0.0 & 1.0 & 54.5 & 0.0 & 1.0 & 14.0 & 11.5 & 200 \\
\hline L5/1 & 207.636 & 3.0 & 0.5 & 0.0 & 0.0 & 3.5 & 0.0 & 2.5 & 0.0 & 1.0 & 10.6 & 6.0 & 0.0 & 0.5 & 0.5 & 40.2 & 0.0 & 1.0 & 20.6 & 10.1 & 200 \\
\hline L4/M/4 & 207.594 & 0.0 & 0.0 & 0.0 & 2.0 & 4.5 & 0.0 & 5.5 & 0.5 & 0.0 & 4.0 & 18.5 & 0.0 & 0.0 & 0.5 & 49.5 & 0.0 & 1.5 & 12.5 & 1.0 & 200 \\
\hline $\mathrm{L} / \mathrm{M} / 3$ & 207.520 & 0.0 & 0.0 & 0.5 & 0.5 & 2.5 & 0.0 & 2.5 & 0.0 & 0.0 & 14.5 & 19.0 & 0.0 & 0.0 & 0.5 & 49.0 & 0.0 & 1.5 & 9.5 & 0.0 & 200 \\
\hline $\mathrm{L} 4 / \mathrm{M} / 2$ & 207.465 & 0.0 & 0.5 & 2.0 & 0.5 & 1.0 & 0.0 & 2.0 & 0.5 & 0.0 & 13.5 & 18.0 & 0.5 & 0.0 & 2.5 & 44.0 & 0.0 & 3.5 & 10.5 & 1.0 & 200 \\
\hline L4/M/1 & 207.428 & 0.0 & 0.0 & 0.5 & 0.0 & 0.0 & 0.0 & 0.0 & 0.0 & 0.0 & 4.0 & 10.5 & 0.0 & 0.0 & 0.0 & 75.5 & 0.0 & 0.5 & 8.0 & 1.0 & 200 \\
\hline L4/6 & 207.400 & 0.0 & 0.0 & 0.0 & 0.0 & 1.5 & 0.0 & 1.0 & 1.0 & 0.0 & 18.8 & 12.2 & 0.0 & 0.0 & 0.5 & 54.8 & 0.0 & 0.5 & 6.6 & 3.0 & 200 \\
\hline$L 4 / 4$ & 207.302 & 0.0 & 0.5 & 1.0 & 0.5 & 2.5 & 0.0 & 3.5 & 0.0 & 0.0 & 12.0 & 13.0 & 0.0 & 0.0 & 1.0 & 51.5 & 0.0 & 1.0 & 10.5 & 3.0 & 200 \\
\hline$L 4 / 3$ & 207.176 & 0.0 & 0.0 & 0.0 & 1.0 & 1.5 & 0.5 & 6.0 & 0.0 & 0.0 & 15.5 & 15.0 & 0.0 & 0.0 & 1.0 & 37.5 & 0.0 & 3.5 & 15.0 & 3.5 & 200 \\
\hline L4/1 & 207.000 & 0.0 & 0.0 & 0.0 & 2.2 & 2.2 & 0.0 & 4.3 & 0.0 & 0.0 & 10.9 & 23.9 & 0.0 & 0.0 & 2.2 & 37.0 & 0.0 & 0.0 & 17.4 & 0.0 & 6 \\
\hline L3/M/2 & 206.922 & 0.0 & 0.0 & 5.6 & 0.0 & 0.0 & 0.0 & 5.6 & 0.0 & 0.0 & 0.0 & 11.1 & 0.0 & 0.0 & 0.0 & 66.7 & 0.0 & 5.6 & 5.6 & 0.0 & 18 \\
\hline L3/M/1 & 206.829 & 0.0 & 0.0 & 81.5 & 0.0 & 0.5 & 0.0 & 1.5 & 0.0 & 0.0 & 2.5 & 4.5 & 0.0 & 0.0 & 0.0 & 8.5 & 0.0 & 0.5 & 0.5 & 0.0 & 200 \\
\hline L3/7 & 206.800 & 0.0 & 0.5 & 66.5 & 0.0 & 1.0 & 0.0 & 0.0 & 0.0 & 0.0 & 8.0 & 4.0 & 0.0 & 0.0 & 0.5 & 19.0 & 0.0 & 0.0 & 0.5 & 0.0 & 200 \\
\hline $\mathrm{L} 3 / 5$ & 206.699 & 0.0 & 0.5 & 8.5 & 0.0 & 4.0 & 0.0 & 3.0 & 0.5 & 0.0 & 18.5 & 11.5 & 0.0 & 0.0 & 2.5 & 41.5 & 0.0 & 0.0 & 9.5 & 0.0 & 200 \\
\hline $\mathrm{L} 3 / 3$ & 206.561 & 0.0 & 0.0 & 0.0 & 0.0 & 4.0 & 0.0 & 0.0 & 1.0 & 0.0 & 10.0 & 11.0 & 0.0 & 0.0 & 2.5 & 64.0 & 1.0 & 1.5 & 5.0 & 0.0 & 200 \\
\hline L3/1 & 206.460 & 0.0 & 2.0 & 2.0 & 0.0 & 5.0 & 0.0 & 7.5 & 3.5 & 0.0 & 8.5 & 15.5 & 0.5 & 0.0 & 1.5 & 43.5 & 1.0 & 3.5 & 6.0 & 0.0 & 200 \\
\hline L2/M/1 & 206.401 & 0.0 & 0.5 & 4.0 & 0.0 & 3.5 & 0.0 & 1.5 & 1.0 & 0.0 & 15.5 & 8.5 & 0.0 & 0.0 & 0.5 & 50.0 & 0.0 & 2.5 & 7.0 & 5.5 & 200 \\
\hline L2/8 & 206.300 & 0.0 & 0.0 & 83.5 & 0.0 & 1.0 & 0.0 & 0.0 & 0.0 & 0.0 & 1.5 & 1.0 & 0.0 & 0.0 & 0.5 & 10.5 & 0.0 & 0.5 & 1.5 & 0.0 & 200 \\
\hline L2/6 & 206.226 & 0.0 & 0.0 & 61.0 & 0.0 & 6.0 & 0.0 & 0.5 & 0.0 & 0.0 & 1.5 & 8.0 & 0.0 & 0.0 & 1.5 & 15.5 & 0.0 & 1.5 & 4.5 & 0.0 & 200 \\
\hline L2/4 & 206.172 & 0.0 & 0.0 & 67.0 & 0.0 & 4.0 & 0.0 & 0.0 & 0.0 & 0.0 & 2.5 & 2.5 & 0.0 & 0.0 & 0.5 & 23.5 & 0.0 & 0.0 & 0.0 & 0.0 & 200 \\
\hline $\mathrm{L} 2 / 3$ & 206.137 & 0.0 & 0.0 & 37.0 & 0.0 & 6.0 & 0.0 & 0.0 & 0.0 & 0.0 & 1.5 & 3.5 & 1.0 & 0.0 & 1.0 & 44.0 & 0.0 & 0.0 & 5.0 & 1.0 & 200 \\
\hline L2/1 & 206.041 & 0.0 & 0.0 & 4.2 & 0.0 & 13.9 & 0.0 & 5.6 & 0.0 & 0.0 & 2.8 & 5.6 & 1.4 & 0.0 & 23.6 & 27.8 & 0.0 & 12.5 & 2.8 & 0.0 & 72 \\
\hline $\mathrm{L} 1 / \mathrm{M} / 3$ & 205.970 & 0.0 & 0.0 & 3.5 & 0.0 & 16.0 & 0.0 & 3.5 & 0.0 & 0.0 & 14.5 & 6.5 & 1.0 & 0.0 & 2.5 & 49.0 & 0.0 & 1.0 & 2.5 & 0.0 & 200 \\
\hline $\mathrm{L} 1 / \mathrm{M} / 2$ & 205.935 & 0.0 & 0.0 & 0.5 & 0.0 & 10.5 & 0.0 & 2.0 & 0.5 & 0.0 & 21.0 & 8.5 & 0.0 & 0.0 & 6.0 & 41.5 & 0.5 & 4.0 & 3.0 & 2.0 & 200 \\
\hline L1/M/1 & 205.900 & 0.0 & 0.0 & 0.0 & 0.0 & 0.0 & 0.0 & 0.0 & 0.0 & 0.0 & 50.0 & 0.0 & 0.0 & 0.0 & 0.0 & 50.0 & 0.0 & 0.0 & 0.0 & 0.0 & 2 \\
\hline L1/6 & 205.850 & 0.0 & 0.5 & 0.5 & 0.0 & 5.5 & 0.0 & 1.0 & 0.5 & 0.0 & 8.5 & 15.5 & 0.5 & 0.0 & 1.5 & 46.5 & 0.0 & 3.5 & 15.0 & 1.0 & 200 \\
\hline L1/4 & 205.754 & 0.0 & 0.0 & 0.0 & 0.0 & 19.5 & 0.0 & 0.5 & 0.5 & 0.0 & 4.5 & 6.5 & 0.0 & 0.0 & 1.0 & 53.5 & 0.0 & 3.0 & 10.5 & 0.5 & 200 \\
\hline L1/1 & 205.486 & 0.0 & 0.5 & 0.0 & 0.0 & 7.5 & 0.0 & 7.5 & 0.0 & 0.0 & 7.5 & 10.5 & 0.5 & 0.0 & 11.5 & 34.5 & 0.0 & 8.0 & 9.0 & 3.0 & 200 \\
\hline $\mathrm{LO} / \mathrm{M} / 2$ & 205.400 & 0.0 & 0.0 & 0.0 & 0.0 & 5.0 & 0.0 & 20.0 & 0.0 & 0.0 & 10.5 & 16.0 & 0.0 & 0.0 & 3.5 & 26.5 & 0.0 & 4.5 & 12.5 & 1.5 & 200 \\
\hline LO/M/1 & 205.340 & 0.0 & 0.0 & 0.0 & 0.0 & 0.5 & 0.0 & 1.0 & 0.5 & 0.0 & 8.5 & 4.0 & 0.0 & 0.0 & 2.0 & 77.0 & 0.0 & 2.0 & 4.0 & 0.5 & 200 \\
\hline LO/7 & 205.290 & 0.0 & 0.0 & 0.5 & 0.0 & 5.5 & 0.0 & 0.0 & 0.0 & 0.0 & 4.5 & 0.5 & 0.5 & 0.0 & 1.0 & 73.5 & 0.0 & 1.5 & 12.0 & 0.5 & 200 \\
\hline LO/5 & 205.085 & 0.0 & 0.0 & 1.5 & 0.0 & 3.0 & 0.0 & 2.0 & 0.0 & 0.0 & 8.0 & 3.0 & 1.0 & 0.0 & 1.5 & 59.5 & 0.5 & 5.0 & 15.0 & 0.0 & 200 \\
\hline LO/3 & 204.845 & 0.0 & 0.0 & 2.5 & 0.0 & 1.0 & 0.0 & 3.0 & 0.0 & 0.0 & 23.5 & 7.0 & 1.0 & 0.0 & 2.5 & 46.5 & 0.0 & 4.0 & 9.0 & 0.0 & 200 \\
\hline LO/1 & 204.715 & 0.0 & 0.0 & 0.5 & 0.0 & 2.5 & 0.0 & 2.5 & 0.0 & 0.0 & 15.0 & 17.5 & 0.0 & 0.0 & 3.0 & 49.0 & 0.0 & 4.0 & 5.5 & 0.5 & 200 \\
\hline
\end{tabular}




\begin{tabular}{|c|c|c|c|c|c|c|c|c|c|c|c|c|c|c|c|c|c|c|c|c|c|c|c|c|c|c|c|c|}
\hline 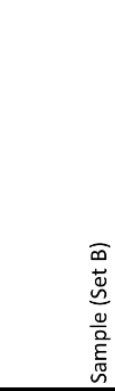 & 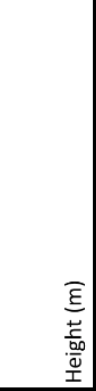 & 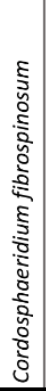 & $\begin{array}{l}0 \\
0 \\
0 \\
5 \\
5 \\
5 \\
0 \\
\frac{d}{0} \\
5 \\
0 \\
\frac{5}{\square} \\
0\end{array}$ & 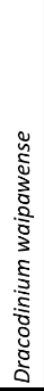 & 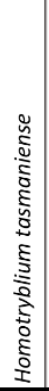 & 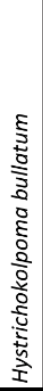 & 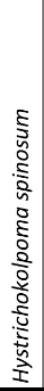 & 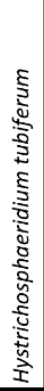 & 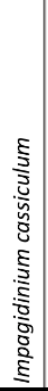 & 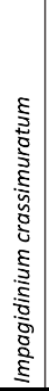 & 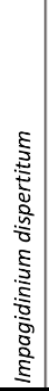 & 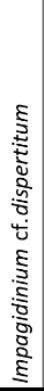 & 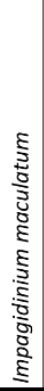 & 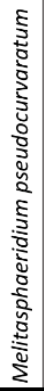 & 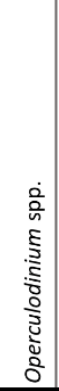 & 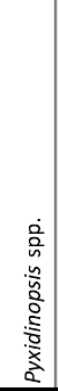 & 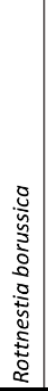 & 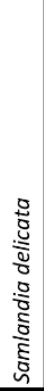 & 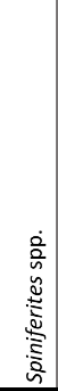 & 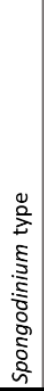 & 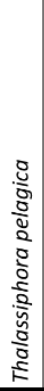 & 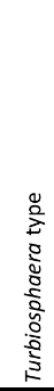 & $\begin{array}{l}\varangle \\
\frac{5}{3} \\
0 \\
\frac{5}{5} \\
5\end{array}$ & 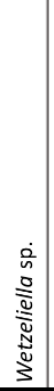 & 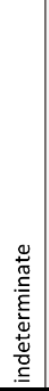 & 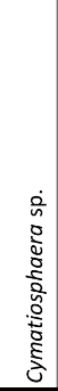 & 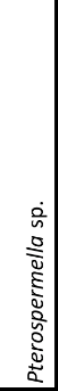 & 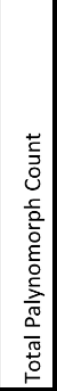 \\
\hline$L 47 / 3$ & 254.640 & 1.0 & 0.0 & 0.0 & 0.0 & 0.5 & 0.0 & 0.0 & 0.0 & 1.0 & 0.0 & 0.5 & 0.5 & 0.0 & 21.0 & 11.0 & 1.0 & 0.5 & 28.5 & 0.5 & 0.0 & 5.0 & 0.5 & 0.0 & 1.5 & 7.0 & 20.0 & 200 \\
\hline L47/1 & 254.304 & 1.0 & 0.0 & 0.0 & 0.0 & 0.5 & 0.0 & 0.0 & 0.5 & 1.5 & 0.0 & 2.5 & 0.0 & 0.0 & 17.5 & 11.5 & 0.0 & 1.5 & 29.5 & 0.0 & 0.0 & 1.5 & 0.5 & 0.0 & 2.5 & 3.5 & 26.0 & 200 \\
\hline L46/M/1 & 254.012 & 1.0 & 0.0 & 0.0 & 0.5 & 0.5 & 2.0 & 0.0 & 0.5 & 1.0 & 0.5 & 0.0 & 0.5 & 0.0 & 14.5 & 2.0 & 0.0 & 0.0 & 64.0 & 0.0 & 0.5 & 2.5 & 3.0 & 2.5 & 0.5 & 0.5 & 3.5 & 200 \\
\hline L46/5 & 253.500 & 2.5 & 0.0 & 0.0 & 0.0 & 0.0 & 0.0 & 0.0 & 0.0 & 0.5 & 0.0 & 0.5 & 0.0 & 2.0 & 19.5 & 4.5 & 0.0 & 1.0 & 32.0 & 0.0 & 0.0 & 10.5 & 4.5 & 2.0 & 1.0 & 3.0 & 16.5 & 200 \\
\hline$L 46 / 3$ & 253.353 & 0.0 & 0.0 & 0.0 & 0.0 & 0.5 & 0.0 & 0.0 & 0.0 & 1.0 & 0.0 & 0.5 & 0.0 & 4.0 & 11.5 & 4.0 & 1.5 & 0.5 & 47.0 & 0.0 & 0.0 & 1.5 & 0.0 & 0.5 & 1.0 & 5.0 & 21.5 & 200 \\
\hline L46/1 & 253.148 & 0.5 & 0.5 & 0.0 & 0.0 & 0.0 & 0.0 & 0.5 & 0.5 & 0.5 & 0.0 & 2.0 & 0.0 & 3.0 & 17.5 & 6.0 & 0.0 & 0.0 & 41.0 & 0.0 & 0.0 & 0.0 & 0.5 & 0.0 & 0.5 & 5.0 & 22.0 & 200 \\
\hline L45/M/1 & 252.990 & 1.0 & 0.0 & 0.5 & 0.0 & 0.0 & 0.0 & 0.0 & 0.0 & 0.5 & 0.0 & 0.0 & 0.0 & 0.0 & 31.5 & 3.0 & 0.0 & 0.5 & 57.0 & 0.0 & 0.0 & 0.0 & 2.5 & 0.0 & 0.0 & 1.5 & 2.0 & 200 \\
\hline L45/6 & 252.780 & 1.5 & 0.0 & 0.0 & 0.0 & 0.5 & 0.5 & 0.0 & 0.0 & 2.0 & 0.0 & 0.0 & 0.5 & 0.5 & 29.5 & 3.5 & 0.0 & 0.5 & 49.5 & 0.0 & 0.0 & 0.0 & 0.0 & 0.0 & 0.5 & 5.5 & 5.5 & 200 \\
\hline$L 45 / 5$ & 252.672 & 0.0 & 0.0 & 0.0 & 0.0 & 0.0 & 0.5 & 0.0 & 0.0 & 0.5 & 1.0 & 0.5 & 0.0 & 0.0 & 29.0 & 7.5 & 0.5 & 1.0 & 33.0 & 0.0 & 0.0 & 0.0 & 0.0 & 0.0 & 1.5 & 4.5 & 20.5 & 200 \\
\hline$L 45 / 3$ & 252.565 & 0.0 & 0.0 & 0.0 & 0.0 & 0.0 & 0.0 & 0.0 & 0.0 & 0.5 & 0.0 & 0.0 & 0.0 & 0.0 & 16.0 & 5.5 & 0.0 & 0.0 & 44.0 & 0.5 & 0.0 & 0.0 & 1.0 & 0.0 & 1.0 & 7.5 & 24.0 & 200 \\
\hline L45/1 & 252.306 & 2.0 & 0.0 & 0.0 & 0.0 & 0.0 & 0.5 & 0.5 & 0.5 & 1.0 & 0.0 & 0.0 & 0.0 & 0.0 & 22.5 & 4.0 & 0.0 & 0.0 & 26.0 & 0.0 & 0.0 & 0.0 & 1.0 & 0.0 & 0.5 & 5.5 & 36.0 & 200 \\
\hline L44/M/1 & 252.091 & 1.0 & 0.0 & 0.0 & 0.5 & 0.0 & 1.5 & 0.0 & 0.0 & 1.5 & 1.0 & 0.0 & 0.0 & 1.0 & 39.5 & 3.5 & 0.0 & 2.5 & 39.5 & 0.0 & 4.5 & 0.0 & 0.5 & 1.0 & 1.0 & 1.5 & 0.0 & 200 \\
\hline L44/6 (b) & 251.900 & 1.0 & 0.0 & 0.5 & 0.0 & 0.0 & 1.0 & 0.0 & 0.0 & 1.0 & 0.5 & 0.5 & 0.5 & 0.0 & 31.0 & 5.0 & 0.0 & 0.0 & 44.0 & 0.5 & 0.5 & 0.0 & 1.5 & 0.5 & 1.0 & 4.5 & 6.5 & 200 \\
\hline L44/4 & 251.743 & 0.0 & 0.0 & 0.5 & 0.0 & 0.0 & 0.0 & 0.0 & 0.5 & 2.5 & 0.0 & 0.0 & 1.0 & 1.0 & 16.0 & 7.0 & 0.5 & 0.5 & 49.5 & 0.0 & 0.0 & 0.0 & 0.5 & 0.0 & 2.5 & 7.5 & 10.5 & 200 \\
\hline$L 44 / 3$ & 251.681 & 0.5 & 0.5 & 0.0 & 0.0 & 0.0 & 0.0 & 2.5 & 0.0 & 0.5 & 0.0 & 0.0 & 0.0 & 0.5 & 13.5 & 5.0 & 0.0 & 1.0 & 55.5 & 0.0 & 0.0 & 0.0 & 0.5 & 0.0 & 2.0 & 12.5 & 5.5 & 200 \\
\hline$\llcorner 44 / 1$ & 251.573 & 0.0 & 0.0 & 0.0 & 0.0 & 0.0 & 0.0 & 6.0 & 0.0 & 1.0 & 0.0 & 0.0 & 0.5 & 0.5 & 13.5 & 14.0 & 0.0 & 0.0 & 38.0 & 0.0 & 0.0 & 0.0 & 0.0 & 0.0 & 0.5 & 11.0 & 15.0 & 200 \\
\hline
\end{tabular}




\begin{tabular}{|c|c|c|c|c|c|c|c|c|c|c|c|c|c|c|c|c|c|c|c|c|c|c|c|}
\hline 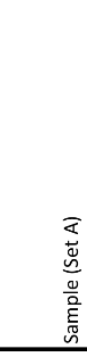 & 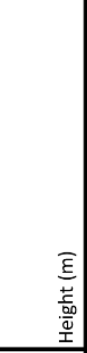 & 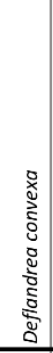 & 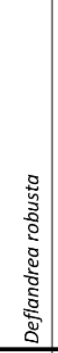 & 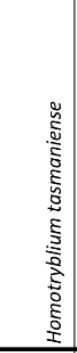 & 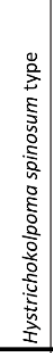 & 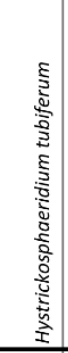 & 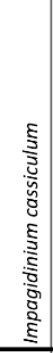 & 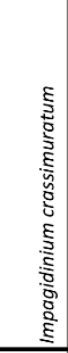 & 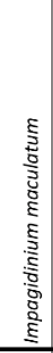 & 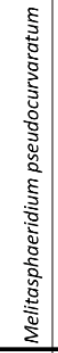 & 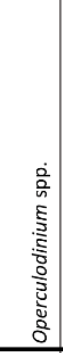 & 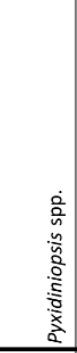 & 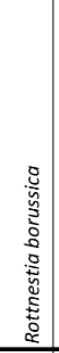 & 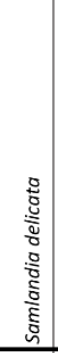 & 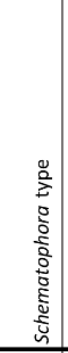 & 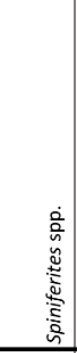 & 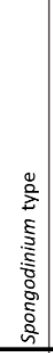 & 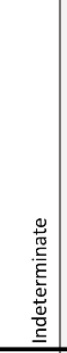 & 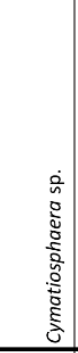 & 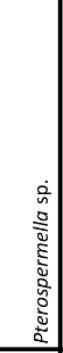 & 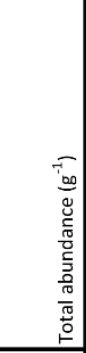 & 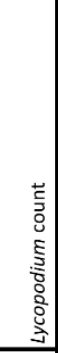 & 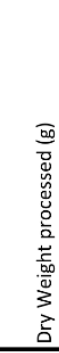 \\
\hline L5/5 & 207.900 & 1.87 & 0.00 & 0.00 & 0.00 & 16.81 & 0.00 & 7.47 & 1.87 & 0.00 & 26.15 & 42.96 & 3.74 & 0.00 & 1.87 & 145.71 & 0.00 & 3.74 & 102.74 & 18.68 & 373.60 & 101 & 110.5 \\
\hline$L 5 / 3$ & 207.747 & 0.00 & 0.00 & 0.00 & 0.00 & 10.88 & 0.00 & 1.21 & 0.00 & 0.00 & 6.05 & 3.63 & 0.00 & 0.00 & 1.21 & 65.89 & 0.00 & 1.21 & 16.93 & 13.90 & 120.91 & 415 & 83.1 \\
\hline L5/1 & 207.636 & 2.41 & 0.40 & 0.00 & 0.00 & 2.81 & 0.00 & 2.01 & 0.00 & 0.80 & 8.44 & 4.82 & 0.00 & 0.40 & 0.40 & 32.16 & 0.00 & 0.80 & 16.48 & 8.04 & 79.99 & 495 & 105.3 \\
\hline L4/M/4 & 207.594 & 0.00 & 0.00 & 0.00 & 1.41 & 3.16 & 0.00 & 3.86 & 0.35 & 0.00 & 2.81 & 13.00 & 0.00 & 0.00 & 0.35 & 34.78 & 0.00 & 1.05 & 8.78 & 0.70 & 70.26 & 548 & 108.3 \\
\hline L4/M/3 & 207.520 & 0.00 & 0.00 & 0.47 & 0.47 & 2.35 & 0.00 & 2.35 & 0.00 & 0.00 & 13.65 & 17.89 & 0.00 & 0.00 & 0.47 & 46.14 & 0.00 & 1.41 & 8.95 & 0.00 & 94.16 & 432 & 102.5 \\
\hline $\mathrm{L} 4 / \mathrm{M} / 2$ & 207.465 & 0.00 & 0.80 & 3.21 & 0.80 & 1.61 & 0.00 & 3.21 & 0.80 & 0.00 & 21.69 & 28.91 & 0.80 & 0.00 & 4.02 & 70.68 & 0.00 & 5.62 & 16.87 & 1.61 & 160.63 & 253 & 102.6 \\
\hline L4/M/1 & 207.428 & 0.00 & 0.00 & 1.12 & 0.00 & 0.00 & 0.00 & 0.00 & 0.00 & 0.00 & 8.95 & 23.49 & 0.00 & 0.00 & 0.00 & 168.93 & 0.00 & 1.12 & 17.90 & 2.24 & 223.75 & 174 & 107.1 \\
\hline$L 4 / 6$ & 207.400 & 0.00 & 0.00 & 0.00 & 0.00 & 1.04 & 0.00 & 0.69 & 0.69 & 0.00 & 12.77 & 8.29 & 0.00 & 0.00 & 0.35 & 37.28 & 0.00 & 0.35 & 4.49 & 2.07 & 68.01 & 682 & 89.9 \\
\hline$L 4 / 4$ & 207.302 & 0.00 & 0.12 & 0.23 & 0.12 & 0.58 & 0.00 & 0.81 & 0.00 & 0.00 & 2.78 & 3.01 & 0.00 & 0.00 & 0.23 & 11.93 & 0.00 & 0.23 & 2.43 & 0.69 & 23.17 & 1541 & 116.8 \\
\hline$L 4 / 3$ & 207.176 & 0.00 & 0.00 & 0.00 & 0.08 & 0.13 & 0.04 & 0.50 & 0.00 & 0.00 & 1.30 & 1.25 & 0.00 & 0.00 & 0.08 & 3.13 & 0.00 & 0.29 & 1.25 & 0.29 & 8.35 & 4215 & 118.4 \\
\hline L4/1 & 207.000 & 0.00 & 0.00 & 0.00 & 0.13 & 0.13 & 0.00 & 0.26 & 0.00 & 0.00 & 0.66 & 1.45 & 0.00 & 0.00 & 0.13 & 2.24 & 0.00 & 0.00 & 1.06 & 0.00 & 6.07 & 1361 & 116.1 \\
\hline L3/M/2 & 206.922 & 0.00 & 0.00 & 0.45 & 0.00 & 0.00 & 0.00 & $\mu^{0.45}$ & 0.00 & 0.00 & 0.00 & 0.89 & 0.00 & 0.00 & 0.00 & 5.36 & 0.00 & 0.45 & 0.45 & 0.00 & 8.04 & 433 & 107.8 \\
\hline L3/M/1 & 206.829 & 0.00 & 0.00 & 988.26 & 0.00 & 6.06 & 0.00 & $18: 19$ & 0.00 & $0: 00$ & 30.31 & 54.57 & 0.00 & 0.00 & 0.00 & 103.07 & 0.00 & 6.06 & 6.06 & 0.00 & 1212.59 & 33 & 104.2 \\
\hline L3/7 & 206.800 & 0.00 & 3.11 & 414.10 & 0.00 & 6.23 & 0.00 & 0.00 & 0.00 & 0.00 & 49.82 & 24.91 & 0.00 & 0.00 & 3.11 & 118.31 & 0.00 & 0.00 & 3.11 & 0.00 & 622.70 & 62 & 108 \\
\hline $\mathrm{L} 3 / 5$ & 206.699 & 0.00 & 2.67 & 45.34 & 0.00 & 21.34 & 0.00 & $16: 00$ & 2.67. & 0.00 & 98.69 & 61.35 & 0.00 . & 0.00 & 13.34 & 221.39 & 0.00 & 0.00 & 50.68 & 0.00 & 533.47 & 80 & 97.7 \\
\hline L3/3 & 206.561 & 0.00 & 0.00 & 0.00 & 0.00 & 2.10 & 0.00 & 0.00 & 0.53 & 0.00 & 5.26 & 5.78 & 0.00 & 0.00 & 1.31 & 33.65 & 0.53 & 0.79 & 2.63 & 0.00 & 52.58 & 746 & 106.3 \\
\hline L3/1 & 206.460 & 0.00 & 0.52 & 0.52 & 0.00 & 1.30 & 0.00 & 1.95 & 0.91 & 0.00 & 2.22 & 4.04 & 0.13 & 0.00 & 0.39 & 11.34 & 0.26 & 0.91 & 1.56 & 0.00 & 26.06 & 1349 & 118.6 \\
\hline L2/M/1 & 206.401 & 0.00 & 0.45 & 3.60 & 0.00 & 3.15 & 0.00 & 1.35 & 0.90 & 0.00 & 13.94 & 7.65 & 0.00 & 0.00 & 0.45 & 44.98 & 0.00 & 2.25 & 6.30 & 4.95 & 89.96 & 434 & 106.8 \\
\hline L2/8 & 206.300 & 0.00 & 0.00 & 289.90 & 0.00 & 3.47 & 0.00 & 0.00 & 0.00 & 0.00 & 5.21 & 3.47 & 0.00 & 0.00 & 1.74 & 36.45 & 0.00 & 1.74 & 5.21 & 0.00 & 347.18 & 103 & 116.6 \\
\hline L2/6 & 206.226 & 0.00 & 0.00 & 850.23 & 0.00 & 83.63 & 0.00 & 6.97 & 0.00 & 0.00 & 20.91 & 111.51 & 0.00 & 0.00 & 20.91 & 216.04 & 0.00 & 20.91 & 62.72 & 0.00 & 1393.82 & 31 & 96.5 \\
\hline L2/4 & 206.172 & 0.00 & 0.00 & 532.00 & 0.00 & 31.76 & 0.00 & 0.00 & 0.00 & 0.00 & 19.85 & 19.85 & 0.00 & 0.00 & 3.97 & 186.60 & 0.00 & 0.00 & 0.00 & 0.00 & 794.03 & 48 & 109.4 \\
\hline $\mathrm{L} 2 / 3$ & 206.137 & 0.00 & 0.00 & 17.17 & 0.00 & 2.78 & 0.00 & 0.00 & 0.00 & 0.00 & 0.70 & 1.62 & 0.46 & 0.00 & 0.46 & 20.42 & 0.00 & 0.00 & 2.32 & 0.46 & 46.41 & 842 & 106.7 \\
\hline L2/1 & 206.041 & 0.00 & 0.00 & 0.14 & 0.00 & 0.48 & 0.00 & 0.19 & 0.00 & 0.00 & 0.10 & 0.19 & 0.05 & 0.00 & 0.81 & 0.95 & 0.00 & 0.43 & 0.10 & 0.00 & 3.44 & 3678 & 118.8 \\
\hline $\mathrm{L} 1 / \mathrm{M} / 3$ & 205.970 & 0.00 & 0.00 & 3.95 & 0.00 & 18.04 & 0.00 & 3.95 & 0.00 & 0.00 & 16.35 & 7.33 & 1.13 & 0.00 & 2.82 & 55.24 & 0.00 & 1.13 & 2.82 & 0.00 & 112.74 & 318 & 116.3 \\
\hline $\mathrm{L} 1 / \mathrm{M} / 2$ & 205.935 & 0.00 & 0.00 & 0.17 & 0.00 & 3.50 & 0.00 & 0.67 & 0.17 & 0.00 & 7.00 & 2.83 & 0.00 & 0.00 & 2.00 & 13.83 & 0.17 & 1.33 & 1.00 & 0.67 & 33.32 & 1164 & 107.5 \\
\hline $\mathrm{L} 1 / \mathrm{M} / 1$ & 205.900 & 0.00 & 0.00 & 0.00 & 0.00 & 0.00 & 0.00 & 0.00 & 0.00 & 0.00 & 6.19 & 0.00 & 0.00 & 0.00 & 0.00 & 6.19 & 0.00 & 0.00 & 0.00 & 0.00 & 12.39 & 30 & 112.2 \\
\hline L1/6 & 205.850 & 0.00 & 0.27 & 0.27 & 0.00 & 2.96 & 0.00 & 0.54 & 0.27 & 0.00 & 4.57 & 8.34 & 0.27 & 0.00 & 0.81 & 25.02 & 0.00 & 1.88 & 8.07 & 0.54 & 53.80 & 663 & 116.9 \\
\hline $\mathrm{L} 1 / 4$ & 205.754 & 0.00 & 0.00 & 0.00 & 0.00 & 22.01 & 0.00 & 0.56 & 0.56 & 0.00 & 5.08 & 7.34 & 0.00 & 0.00 & 1.13 & 60.39 & 0.00 & 3.39 & 11.85 & 0.56 & 112.88 & 451 & 81.9 \\
\hline L1/1 & 205.486 & 0.00 & 0.05 & 0.00 & 0.00 & 0.75 & 0.00 & 0.75 & 0.00 & 0.00 & 0.75 & 1.05 & 0.05 & 0.00 & 1.15 & 3.44 & 0.00 & 0.80 & 0.90 & 0.30 & 9.98 & 4101 & 101.9 \\
\hline $\mathrm{LO} / \mathrm{M} / 2$ & 205.400 & 0.00 & 0.00 & 0.00 & 0.00 & 2.80 & 0.00 & 111.20 & 0.00 & 0.00 & 5.88 & 8.96 & 0.00 & 0.00 & 1.96 & 14.84 & 0.00 & 2.52 & 7.00 & 0.84 & 55.99 & 677 & 110 \\
\hline LO/M/1 & 205.340 & 0.00 & 0.00 & 0.00 & 0.00 & 0.86 & 0.00 & 1.72 & 0.86 & 0.00 & 14.65 & 6.89 & 0.00 & 0.00 & 3.45 & 132.67 & 0.00 & 3.45 & 6.89 & 0.86 & 172.30 & 221 & 109.5 \\
\hline LO/7 & 205.290 & 0.00 & 0.00 & 0.60 & 0.00 & 6.55 & 0.00 & 0.00 & 0.00 & 0.00 & 5.36 & 0.60 & 0.60 & 0.00 & 1.19 & 87.51 & 0.00 & 1.79 & 14.29 & 0.60 & 119.06 & 342 & 102.4 \\
\hline LO/5 & 205.085 & 0.00 & 0.00 & 2.82 & 0.00 & 5.65 & 0.00 & 3.76 & 0.00 & 0.00 & 15.06 & 5.65 & 1.88 & 0.00 & 2.82 & 111.98 & 0.94 & 9.41 & 28.23 & 0.00 & 188.20 & 211 & 105 \\
\hline Lo/3 & 204.845 & 0.00 & 0.00 & 6.79 & 0.00 & 2.72 & 0.00 & 8.15 & 0.00 & 0.00 & 63.81 & 19.01 & 2.72 & 0.00 & 6.79 & 126.26 & 0.00 & 10.86 & 24.44 & 0.00 & 271.52 & 134 & 114.6 \\
\hline LO/1 & 204.715 & 0.00 & 0.00 & 0.46 & 0.00 & 2.30 & 0.00 & 2.30 & 0.00 & 0.00 & 13.82 & 16.13 & 0.00 & 0.00 & 2.76 & 45.15 & 0.00 & 3.69 & 5.07 & 0.46 & 92.15 & 399 & 113.4 \\
\hline
\end{tabular}


Set B Absolute Abundance $\left(\mathrm{g}^{-1}\right)$

\begin{tabular}{|c|c|c|c|c|c|c|c|c|c|c|c|c|c|c|c|c|c|c|c|c|c|c|c|c|c|c|c|c|c|c|c|}
\hline 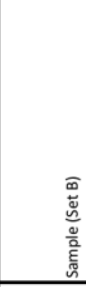 & 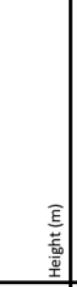 & 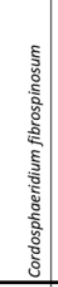 & 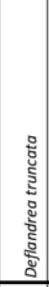 & 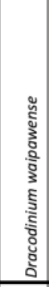 & 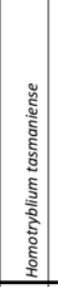 & 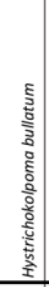 & 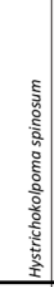 & 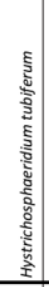 & 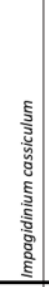 & 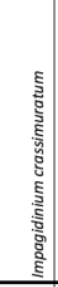 & 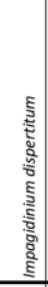 & 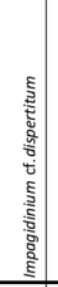 & 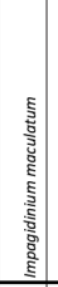 & 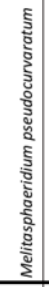 & 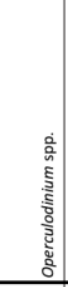 & 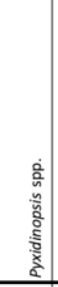 & 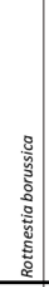 & 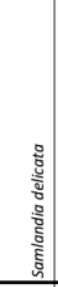 & 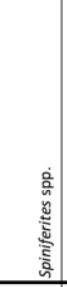 & 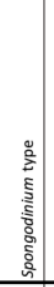 & 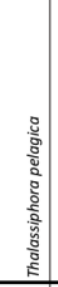 & 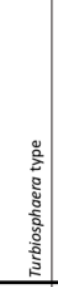 & 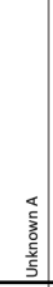 & 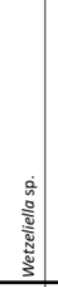 & 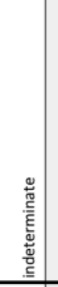 & & 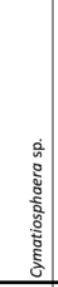 & 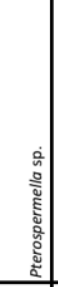 & 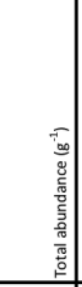 & 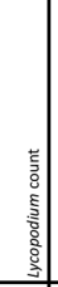 & 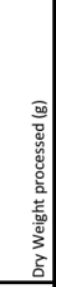 \\
\hline $47 / 3$ & 640 & 0.33 & 0.00 & 0.00 & 0.00 & 0.16 & 0.00 & 0.00 & 0.00 & 0.33 & 0.00 & 0.16 & 0.16 & 0.00 & 6.86 & 3.60 & 0.33 & 0.16 & 9.31 & 0.16 & 0.00 & 1.63 & 0.16 & 0.00 & 0.49 & 0.00 & 2.29 & 6.54 & 2.68 & 1125 & 13.4 \\
\hline$\lfloor 47 / 1$ & 4.304 & 0.45 & 0.00 & 0.00 & 0.00 & 0.22 & 0.00 & 0.00 & 0.22 & 0.67 & 0.00 & 1.12 & 0.00 & 0.00 & 7.87 & 5.17 & 0.00 & 0.67 & 13.27 & 0.00 & 0.00 & 0.67 & 0.22 & 0.00 & 1.12 & 0.00 & 1.57 & 11.70 & 44.99 & 844 & 109.8 \\
\hline$\llcorner 46 / \mathrm{M} / 1$ & 254.012 & 3.55 & 0.00 & 0.00 & 1.78 & 1.78 & 7.11 & 0.00 & 1.78 & 3.55 & 1.78 & 0.00 & 1.78 & 0.00 & 51.54 & 7.11 & 0.00 & 0.00 & 227.50 & 0.00 & 1.78 & 8.89 & 10.66 & 8.89 & 1.78 & 0.00 & 1.78 & 12.44 & 355.46 & 100 & 117 \\
\hline L46/5 & .500 & 4.39 & 0.00 & 0.00 & 0.00 & 0.00 & 0.00 & 0.00 & 0.00 & 0.88 & 0.00 & 0.88 & 0.00 & 3.51 & 34.24 & 7.90 & 0.00 & 1.76 & 56.18 & 0.00 & 0.00 & 18.43 & 90 & 3.51 & 1.76 & 0.00 & 5.27 & 28.97 & 175.57 & 301 & 78.9 \\
\hline L446/3 & 3.353 & 0.00 & 0.00 & 0.00 & 0.00 & 0.25 & 0.00 & 0.00 & 0.00 & 0.51 & 0.00 & 0.25 & 0.00 & 2.04 & 5.85 & 2.04 & 0.76 & 0.25 & 23.92 & 0.00 & 0.00 & 0.76 & 0.00 & 0.25 & 0.51 & 0.00 & 2.54 & 10.94 & 50.90 & 696 & 117.7 \\
\hline L46/1 & 253.148 & 0.17 & 0.17 & 0.00 & 0.00 & 0.00 & 0.00 & 0.17 & 0.17 & 0.17 & 0.00 & 0.68 & 0.00 & 1.02 & 5.96 & 2.05 & 0.00 & 0.00 & 13.97 & 0.00 & 0.00 & 0.00 & 0.17 & 0.00 & 0.17 & 0.00 & 1.70 & 7.50 & 34.08 & 1411 & 86.7 \\
\hline $145 / \mathrm{M} / 1$ & 252.990 & 12.50 & 0.00 & 6.25 & 0.00 & 0.00 & 0.00 & 0.00 & 0.00 & 6.25 & 0.00 & 0.00 & 0.00 & 0.00 & 393.76 & 37.50 & 0.00 & 6.25 & 712.52 & 0.00 & 0.00 & 0.00 & 31.25 & 0.00 & 0.00 & 0.00 & 18.75 & 25.00 & 1250.03 & 31 & 107.6 \\
\hline 445 & 780 & 2.6 & 0. & 0. & 0.00 & 0.9 & 0.90 & 0.00 & 0.00 & 3.58 & 0.00 & 0.00 & 0.90 & 0.90 & 52.87 & 6.27 & 0.00 & 0.90 & 88.72 & 0.00 & 0.00 & 0.00 & 0.00 & 0.00 & 0.90 & 0.00 & 9.86 & 9.86 & 179.24 & 216 & 107.7 \\
\hline & & & & & 0.00 & 0.00 & & 0.00 & 0.0 & & & 0.54 & 000 & 0.00 & & & & & 3589 & 0.00 & & & 0.00 & 0.00 & 1.63 & & 4.89 & $22,30 \mathrm{l}$ & 108.76 & 361 & 106.2 \\
\hline $145 / 3$ & .565 & 0.00 & 0.00 & 0.00 & 0.00 & 0.00 & 0.00 & 0.00 & 0.00 & 0.43 & 0.00 & 0.00 & 0.00 & 0.00 & 13.67 & 4.70 & 0.00 & 0.00 & 37.59 & 0.43 & 0.00 & 0.00 & 0.85 & 0.00 & 0.85 & 0.00 & 6.41 & 20.50 & 85.42 & 468 & 104.3 \\
\hline L45/1 & 252.306 & 0.75 & 0.00 & 0.00 & 0.00 & 0.00 & 0.19 & 0.19 & 0.19 & 0.37 & 0.00 & 0.00 & 0.00 & 0.00 & 8.38 & 1.49 & 0.00 & 0.00 & 9.69 & 0.00 & 0.00 & 0.00 & 0.37 & 0.00 & 0.19 & 0.00 & 2.05 & 13.41 & 37.26 & 1040 & 107.6 \\
\hline L44/M/1 & 252.091 & 7.02 & 0.00 & 0.00 & 3.51 & 0.00 & 10.53 & 0.00 & 0.00 & 10.53 & 7.02 & 0.00 & 0.00 & 7.02 & 277.35 & 24.57 & 0.00 & 17.55 & 277.35 & 0.00 & 31.60 & 0.00 & 3.51 & 7.02 & 7.02 & 0.00 & 10.53 & 0.00 & 702.14 & 52 & 114.2 \\
\hline $4 / 6$ (b) & 900 & 2.58 & 00 & 1. & 0.00 & 0.00 & 2.58 & 0.00 & 0.00 & 2.58 & 1.29 & $29 \mid$ & 1.29 & 0.00 & 9.85 & 12.88 & 0.00 & 0.00 & 113.33 & 1.29 & 1.2 & 0.00 & 3.86 & 1.29 & 2.58 & 0.00 & 11.59 & 16.74 & 57.57 & 142 & 14 \\
\hline & & 0.00 & 0.00 & & 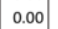 & 0. & 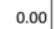 & 0 & 0.62 & 12 & 0.00 & 0 & 1.25 & 1.2 & 8 & 74 & 0.62 & 0.62 & 1.80 & 0.00 & .00 & .00 & 0.62 & 0.00 & 3.12 & 00 & 9.36 & 13.11 & 124.85 & 313 & 106.7 \\
\hline L44 & & 0.5 & 0. & 0. & $0 . c$ & 0.0 & 0 & 2.76 & 0.00 & 55 & 0.00 & 0.00 & 0.00 & 0.5 & 14. & 5.51 & 0.00 & 1.1 & 1.18 & 0.00 & 0.00 & 0.00 & 55 & 0.00 & 2.20 & 0.00 & 13.78 & 6.06 & 110.24 & 320 & 1 \\
\hline $14 / 1$ & 1.573 & 0.00 & 0.00 & 0.00 & 0.00 & 0.00 & 0.00 & 3.10 & 0.00 & 0.52 & 0.00 & 0.00 & 0.26 & 0.26 & 6.98 & 7.24 & 0.00 & 0.00 & 19.65 & 0.00 & 0.00 & 0.00 & 0.00 & 0.00 & 0.26 & 0.00 & 5.69 & 7.76 & 51.71 & 735 & 109.7 \\
\hline
\end{tabular}




\begin{tabular}{|c|c|c|c|c|c|c|c|c|c|c|c|c|c|c|c|c|c|c|c|}
\hline \multirow[b]{2}{*}{ 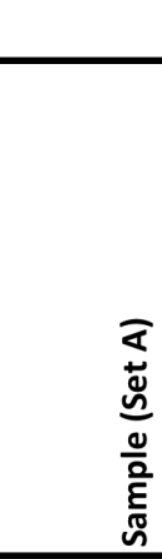 } & \multirow[b]{2}{*}{ 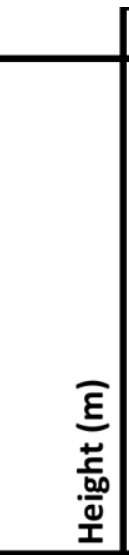 } & \multicolumn{8}{|c|}{ Palynomorphs } & \multicolumn{6}{|c|}{ Phytoclasts } & \multirow[b]{2}{*}{$\begin{array}{l}\Sigma \\
0 \\
\frac{0}{0} \\
\overline{5} \\
0 \\
\end{array}$} & \multirow[b]{2}{*}{ 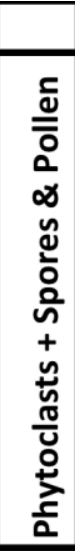 } & \multirow[b]{2}{*}{$\begin{array}{l}z \\
z \\
z\end{array}$} & \multirow[t]{2}{*}{ Total } \\
\hline & & 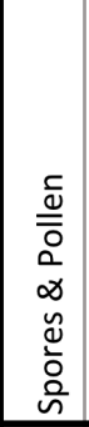 & 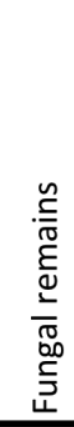 & 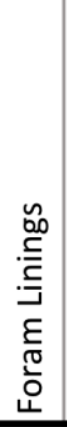 & 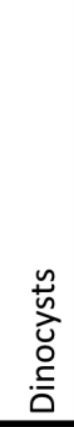 & 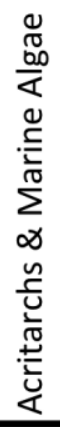 & 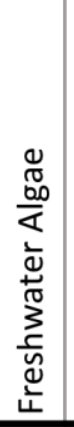 & $\begin{array}{l}\text { c } \\
\frac{0}{2} \\
\vdots \\
\varepsilon \\
0 \\
0 \\
N\end{array}$ & 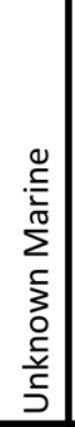 & 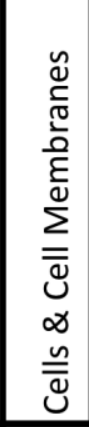 & 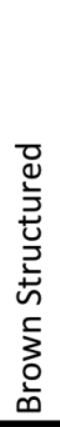 & 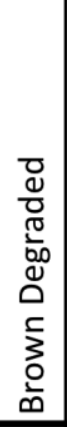 & 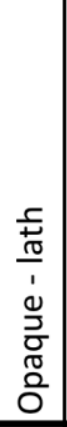 & 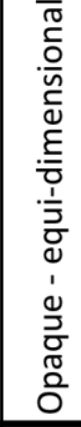 & 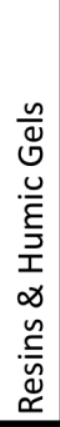 & & & & \\
\hline $\mathrm{L} 5 / 5$ & 207.90 & 2 & 1 & 0 & 46 & 26 & 0 & 0 & 0 & 9 & 5 & 6 & 18 & 51 & 6 & 130 & 98 & 72 & 300 \\
\hline L5/3 & 207.75 & 0 & 0 & 0 & 0 & 3 & 0 & 0 & 0 & 3 & 0 & 0 & 8 & 36 & 1 & 249 & 48 & 3 & 300 \\
\hline $\mathrm{L} 5 / 1$ & 207.64 & 7 & 6 & 0 & 33 & 49 & 0 & 0 & 이 & 19 & 16 & 6 & 11 & 56 & 13 & 84 & 134 & 82 & 300 \\
\hline L4/M/4 & 207.59 & 7 & 2 & 0 & 19 & 5 & 0 & 0 & 이 & 30 & 5 & 11 & 5 & 66 & 9 & 141 & 135 & 24 & 300 \\
\hline L4/M/3 & 207.52 & 6 & 3 & 0 & 25 & 3 & 0 & 0 & 0 & 29 & 9 & 4 & 6 & 176 & 4 & 35 & 237 & 28 & 300 \\
\hline L4/M/2 & 207.47 & 7 & 3 & 0 & 22 & 5 & 0 & 0 & 0 & 16 & 5 & 14 & 4 & 95 & 2 & 127 & 146 & 27 & 300 \\
\hline L4/M/1 & 207.43 & 1 & 4 & 1 & 8 & 1 & 0 & 0 & 이 & 8 & 5 & 4 & 0 & 13 & 2 & 253 & 37 & 10 & 300 \\
\hline L4/6 & 207.40 & 0 & 1 & 0 & 13 & 4 & 0 & 0 & 0 & 3 & 1 & 1 & 6 & 21 & 5 & 245 & 38 & 17 & 300 \\
\hline L4/4 & 207.30 & 0 & 0 & 0 & 2 & 4 & 0 & 0 & 0 & 2 & 0 & 0 & 1 & 4 & 0 & 287 & 7 & 6 & 300 \\
\hline L4/3 & 207.18 & 1 & 0 & 0 & 1 & 3 & 0 & 0 & 이 & 3 & 0 & 0 & 0 & 3 & 1 & 288 & 8 & 4 & 300 \\
\hline L4/1 & 207.00 & 3 & 2 & 0 & 3 & 14 & 0 & 0 & 이 & 6 & 17 & 6 & 2 & 51 & 6 & 190 & 93 & 17 & 300 \\
\hline $\mathrm{L} 3 / \mathrm{M} / 2$ & 206.92 & 26 & 14 & 0 & 0 & 1 & 0 & 0 & 0 & 15 & 21 & 15 & 2 & 103 & 15 & 88 & 211 & 1 & 300 \\
\hline L3/M/1 & 206.83 & 0 & 1 & 0 & 66 & 1 & 0 & 0 & 0 & 13 & 4 & 7 & 4 & 200 & 2 & 2 & 231 & 67 & 300 \\
\hline L3/7 & 206.80 & 0 & 0 & 1 & 63 & 7 & 0 & 0 & 0 & 8 & 4 & 3 & 8 & 13 & 4 & 189 & 40 & 71 & 300 \\
\hline L3/5 & 206.70 & 4 & 0 & 0 & 46 & 8 & 0 & 0 & 0 & 12 & 6 & 4 & 6 & 34 & 1 & 179 & 67 & 54 & 300 \\
\hline L3/3 & 206.56 & 0 & 0 & 0 & 5 & 5 & 0 & 0 & 1 & 6 & 1 & 2 & 2 & 7 & 3 & 268 & 21 & 11 & 300 \\
\hline L3/1 & 206.46 & 0 & 2 & 0 & 3 & 2 & 0 & 0 & 이 & 13 & 10 & 3 & 3 & 35 & 7 & 222 & 73 & 5 & 300 \\
\hline $\mathrm{L} 2 / \mathrm{M} / 1$ & 206.40 & 10 & 24 & 0 & 22 & 5 & 0 & 0 & 0 & 53 & 39 & 6 & 7 & 70 & 7 & 57 & 216 & 27 & 300 \\
\hline L2/8 & 206.30 & 2 & 0 & 0 & 50 & 2 & 0 & 0 & 0 & 11 & 6 & 2 & 1 & 6 & 3 & 217 & 31 & 52 & 300 \\
\hline L2/6 & 206.23 & 1 & 1 & 0 & 119 & 8 & 0 & 0 & 0 & 15 & 4 & 1 & 2 & 10 & 3 & 136 & 37 & 127 & 300 \\
\hline L2/4 & 206.17 & 0 & 0 & 0 & 57 & 7 & 0 & 0 & 0 & 6 & 6 & 1 & 0 & 18 & 1 & 204 & 32 & 64 & 300 \\
\hline L2/3 & 206.14 & 2 & 0 & 0 & 3 & 1 & 0 & 0 & 0 & 4 & 3 & 0 & 0 & 8 & 1 & 278 & 18 & 4 & 300 \\
\hline $\mathrm{L} 2 / 1$ & 206.04 & 3 & 0 & 0 & 5 & 3 & 0 & 0 & 0 & 14 & 9 & 4 & 2 & 13 & 2 & 245 & 47 & 8 & 300 \\
\hline $\mathrm{L} 1 / \mathrm{M} / 3$ & 205.97 & 17 & 24 & 0 & 9 & 0 & 0 & 2 & 0 & 91 & 71 & 30 & 0 & 26 & 4 & 26 & 263 & 9 & 300 \\
\hline L1/M/2 & 205.94 & 7 & 20 & 0 & 2 & 1 & 0 & 0 & 2 & 15 & 25 & 19 & 5 & 100 & 4 & 100 & 195 & 5 & 300 \\
\hline L1/M/1 & 205.90 & 1 & 0 & 0 & 0 & 0 & 0 & 0 & 0 & 0 & 3 & 5 & 6 & 84 & 1 & 200 & 100 & 0 & 300 \\
\hline L1/6 & 205.85 & 1 & 3 & 0 & 20 & 7 & 0 & 0 & 0 & 18 & 5 & 4 & 0 & 15 & 8 & 219 & 54 & 27 & 300 \\
\hline $\mathrm{L} 1 / 4$ & 205.75 & 0 & 1 & 0 & 11 & 0 & 0 & 0 & 0 & 2 & 1 & 1 & 2 & 9 & 2 & 271 & 18 & 11 & 300 \\
\hline $\mathrm{L} 1 / 1$ & 205.49 & 0 & 1 & 0 & 1 & 1 & 0 & 0 & 0 & 7 & 7 & 3 & 2 & 17 & 2 & 259 & 39 & 2 & 300 \\
\hline LO/M/2 & 205.40 & 16 & 102 & 1 & 5 & 0 & 0 & 3 & 0 & 37 & 57 & 19 & 2 & 37 & 20 & 1 & 290 & 6 & 300 \\
\hline LO/M/1 & 205.34 & 4 & 2 & 0 & 19 & 1 & 0 & 0 & 0 & 24 & 0 & 6 & 5 & 73 & 6 & 160 & 120 & 20 & 300 \\
\hline LO/7 & 205.29 & 0 & 0 & 0 & 13 & 1 & 0 & 0 & 이 & 3 & 3 & 0 & 1 & 8 & 1 & 270 & 16 & 14 & 300 \\
\hline LO/5 & 205.09 & 0 & 1 & 0 & 22 & 6 & 0 & 0 & 0 & 8 & 19 & 1 & 5 & 27 & 11 & 200 & 72 & 28 & 300 \\
\hline LO/3 & 204.85 & 1 & 0 & 0 & 15 & 7 & 0 & 0 & 0 & 1 & 0 & 0 & 2 & 3 & 1 & 270 & 8 & 22 & 300 \\
\hline LO/1 & 204.72 & 2 & 0 & 0 & 41 & 5 & 0 & 0 & 0 & 11 & 3 & 4 & 1 & 13 & 4 & 216 & 38 & 46 & 300 \\
\hline
\end{tabular}




\begin{tabular}{|c|c|c|c|c|c|c|c|c|c|c|c|c|c|c|c|c|c|c|c|}
\hline & & Palyr & omo & phs & & & & & & Phytc & clas & & & & & & & & Total \\
\hline 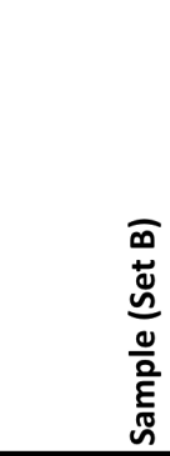 & 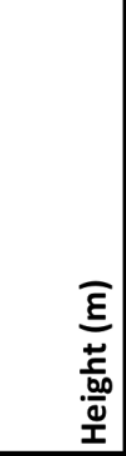 & 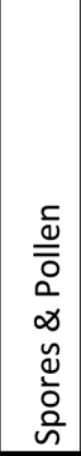 & 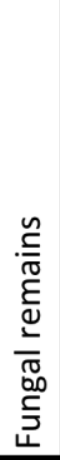 & 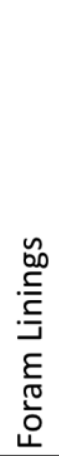 & 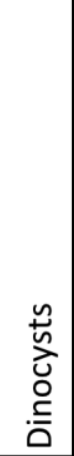 & 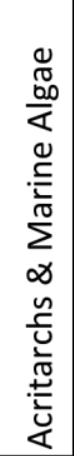 & 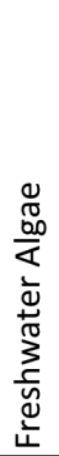 & 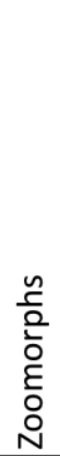 & 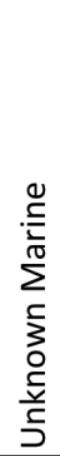 & 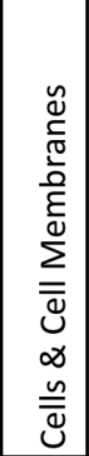 & 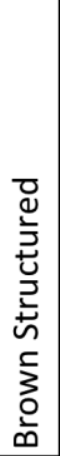 & $\begin{array}{l}0 \\
\frac{d}{0} \\
\frac{\pi}{00} \\
0 \\
0 \\
\frac{1}{0} \\
0 \\
0\end{array}$ & 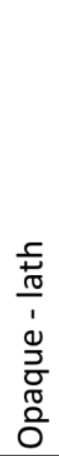 & 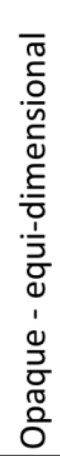 & 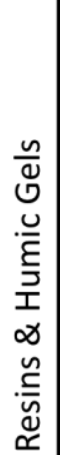 & 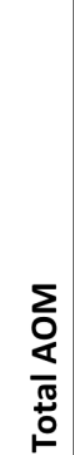 & 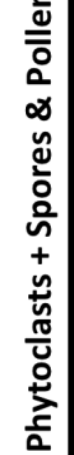 & 운 & \\
\hline L47/3 & 254.64 & 0 & 1 & 0 & 6 & 11 & 0 & 0 & $\overline{0}$ & 8 & 3 & 2 & 8 & 21 & 4 & 236 & 47 & 17 & 300 \\
\hline L47/1 & 254.30 & 6 & 1 & 0 & 7 & 47 & 0 & 0 & 0 & 18 & 4 & 13 & 7 & 22 & 10 & 165 & 81 & 54 & 300 \\
\hline L46/M/1 & 254.01 & 7 & 69 & 0 & 78 & 5 & 0 & 3 & 0 & 33 & 25 & 12 & 10 & 29 & 19 & 10 & 204 & 83 & 300 \\
\hline L46/5 & 253.50 & 9 & 2 & 0 & 66 & 54 & 0 & 0 & 0 & 24 & 3 & 32 & 12 & 46 & 18 & 34 & 146 & 120 & 300 \\
\hline$L 46 / 3$ & 253.35 & 2 & 1 & 0 & 38 & 60 & 0 & 0 & 0 & 13 & 15 & 6 & 3 & 41 & 18 & 103 & 99 & 98 & 300 \\
\hline L46/1 & 253.15 & 3 & 1 & 0 & 24 & 97 & 0 & 0 & 0 & 17 & 4 & 9 & 8 & 30 & 16 & 91 & 88 & 121 & 300 \\
\hline L45/M/1 & 252.99 & 9 & 12 & 0 & 56 & 6 & 0 & 0 & 0 & 19 & 5 & 20 & 7 & 9 & 6 & 151 & 87 & 62 & 300 \\
\hline L45/6 & 252.78 & 0 & 1 & 0 & 70 & 67 & 0 & 0 & 0 & 20 & 5 & 8 & 4 & 27 & 8 & 90 & 73 & 137 & 300 \\
\hline L45/5 & 252.67 & 13 & 0 & 0 & 65 & 62 & 0 & 0 & 0 & 21 & 6 & 6 & 6 & 60 & 14 & 47 & 126 & 127 & 300 \\
\hline L45/4 & 252.61 & 11 & 3 & 0 & 39 & 106 & 0 & 0 & 0 & 14 & 12 & 8 & 12 & 40 & 20 & 35 & 120 & 145 & 300 \\
\hline$L 45 / 3$ & 252.56 & 9 & 3 & 0 & 32 & 75 & 0 & 0 & 0 & 19 & 3 & 20 & 16 & 36 & 12 & 75 & 118 & 107 & 300 \\
\hline L45/1 & 252.31 & 3 & 4 & 0 & 12 & 130 & 0 & 2 & 0 & 25 & 9 & 20 & 6 & 23 & 17 & 49 & 107 & 142 & 300 \\
\hline L44/M/1 & 252.09 & 6 & 34 & 0 & 58 & 0 & 0 & 2 & 0 & 33 & 11 & 25 & 7 & 90 & 5 & 29 & 211 & 58 & 300 \\
\hline L44/6 (b) & 251.90 & 5 & 7 & 0 & 119 & 42 & 0 & 0 & 0 & 32 & 6 & 8 & 1 & 19 & 12 & 49 & 90 & 161 & 300 \\
\hline L44/4 & 251.74 & 6 & 2 & 0 & 112 & 90 & 0 & 0 & 0 & 27 & 4 & 13 & 2 & 15 & 4 & 25 & 73 & 202 & 300 \\
\hline L44/3 & 251.68 & 4 & 0 & 0 & 66 & 81 & 0 & 0 & 0 & 18 & 3 & 5 & 3 & 12 & 6 & 102 & 51 & 147 & 300 \\
\hline L44/1 & 251.57 & 7 & 0 & 0 & 21 & 55 & 0 & 0 & 0 & 11 & 2 & 8 & 4 & 10 & 5 & 177 & 47 & 76 & 300 \\
\hline
\end{tabular}

